\title{
Water Resources of
}

Southern California

With Special Reference

To the Drought of 1944-51

By HAROLD C. TROXELL

GEOLOGICAL SURVEY WATER-SUPPLY PAPER 1366

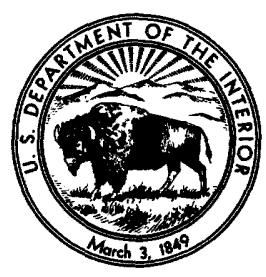




\section{UNITED STATES DEPARTMENT OF THE INTERIOR}

FRED A. SEATON, Secretary

\section{GEOLOGICAL SURVEY}

Thomas B. Nolan, Director 
Abstract.

Introduction.

Purpose and scope

Acknowledgments .

What constitutes a drought?

Hydrologic factors

Climate

Coastal area

Mountain area

Desert area

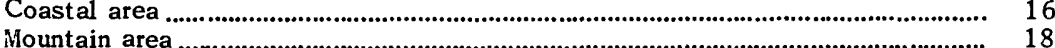

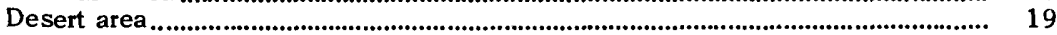

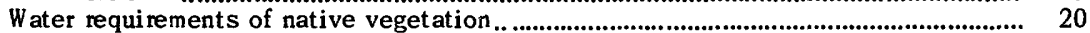

Potential evapotranspiration ....................................................................................... 20

Annual water consumption ........................................................................................ 22

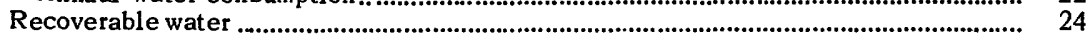

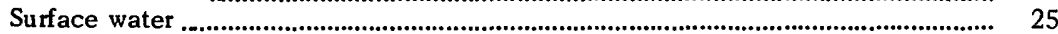

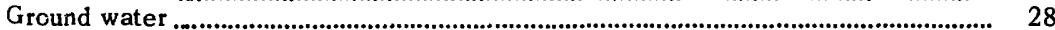

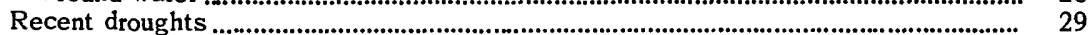

Cultural development......................................................................................................... 29

History of settlement and growth ............................................................................... 29

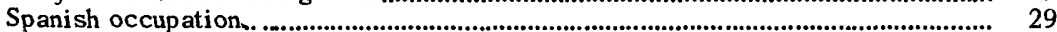

Mission period .......................................................................................................... 30

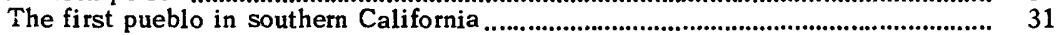

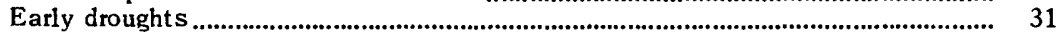

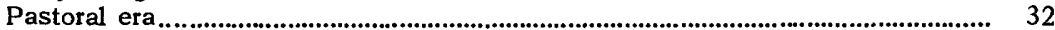

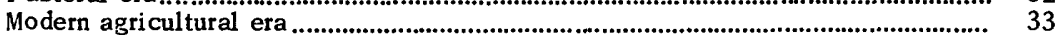

The Great Boom .................................................................................................. 33

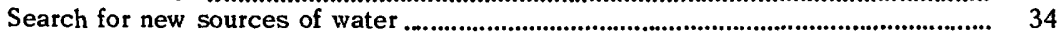

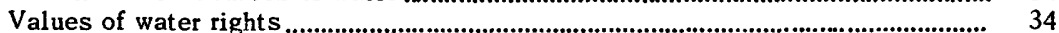

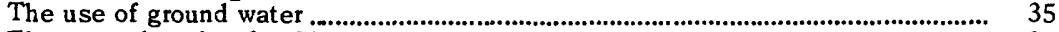

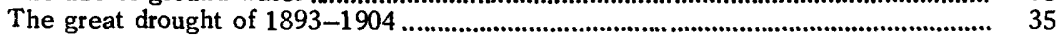

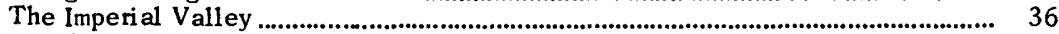

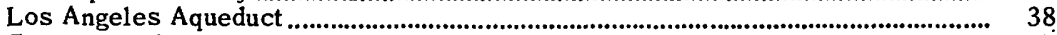

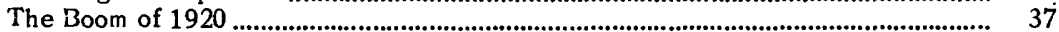

Colorado River Aqueduct.............................................................................................. 38

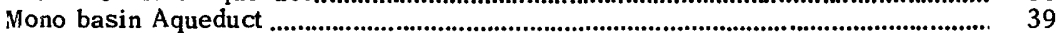

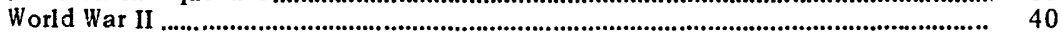

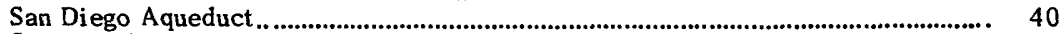

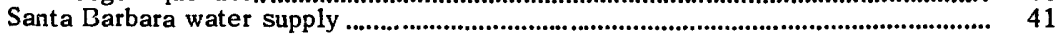

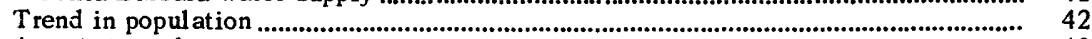

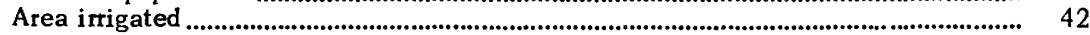

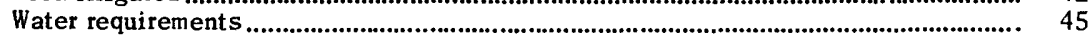

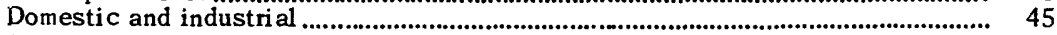

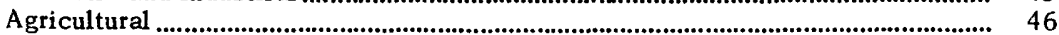

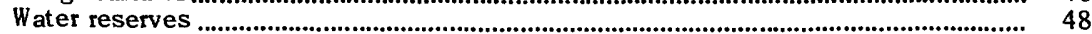

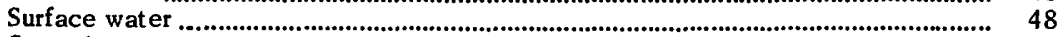

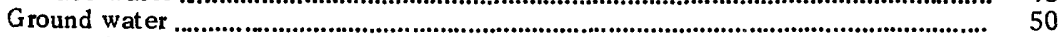

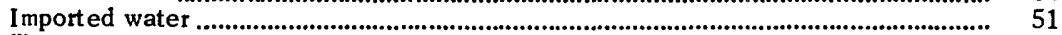

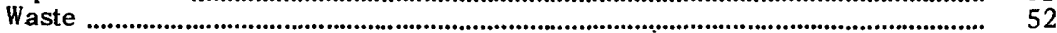


Cultural development-_Continued

Cultural influences on local water supply

Resumé

San Diego region..

Water requirements

Water reserves

Importations

Surface

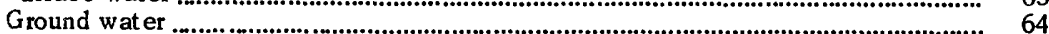

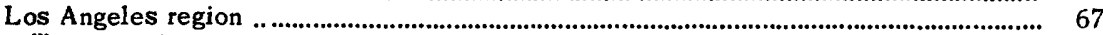

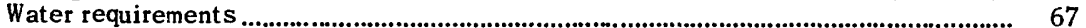

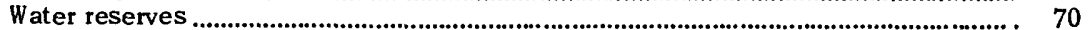

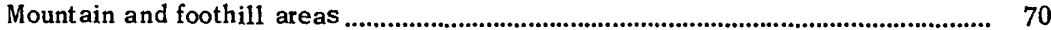

Valley floor areas.................................................................................................. 73

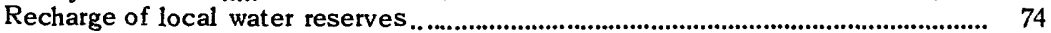

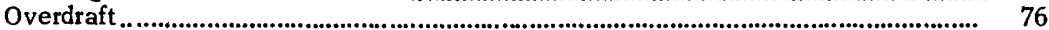

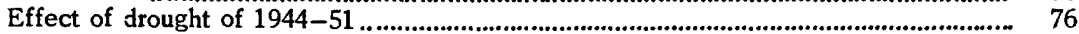

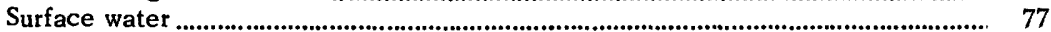

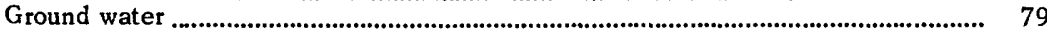

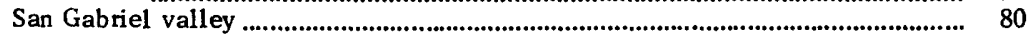

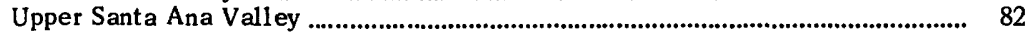

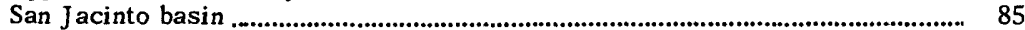

San Fernando Valley .......................................................................................... 87

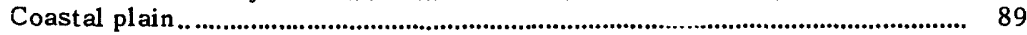

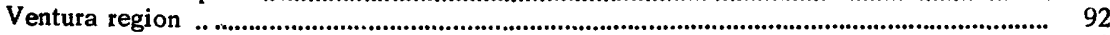

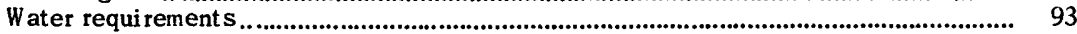

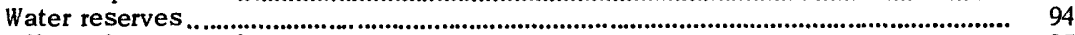

Effect of drought of 1944-51 ................................................................................... 95

Upper Ventura River valley, Fillmore and Santa Paula basins ............................... 95

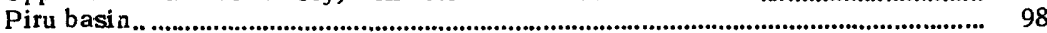

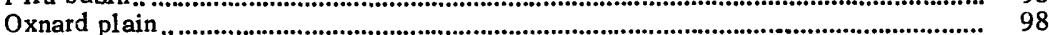

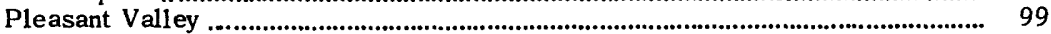

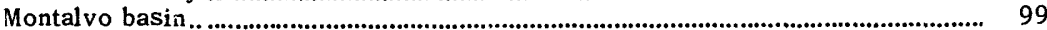

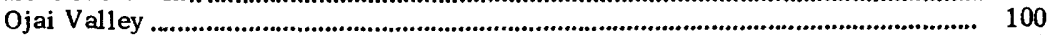

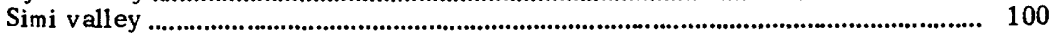

Las Posas valley .............................................................................................. 102

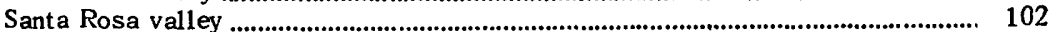

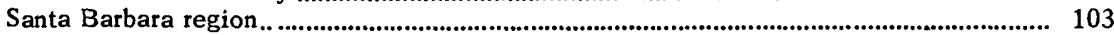

Water requi rements ........................................................................................................ 104

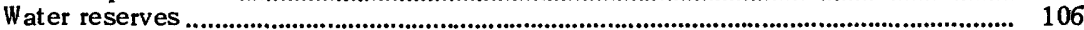

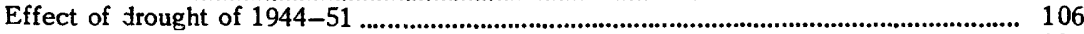

Santa Maria Valley ................................................................................................... 106

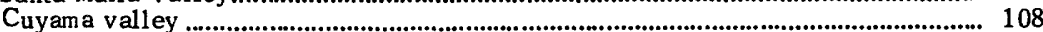

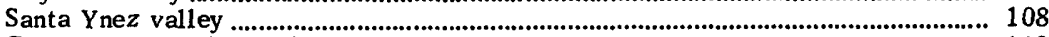

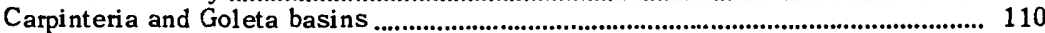

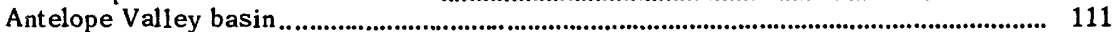

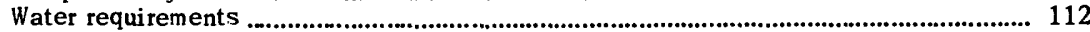

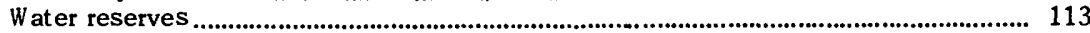

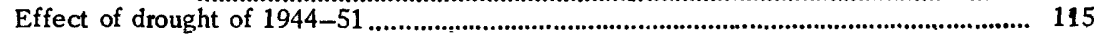

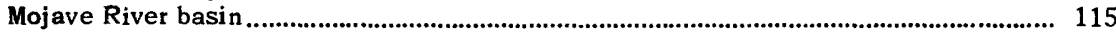

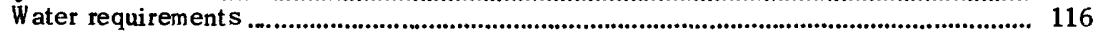

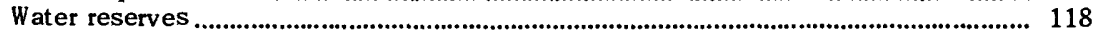

Effect of drought of 1944-51 ................................................................................. 120

Upper Mojave River Valley .................................................................................... 120

Middle Mojave River Valley ................................................................................... 122

Lower Mojave River Valley ......................................................................................... 123

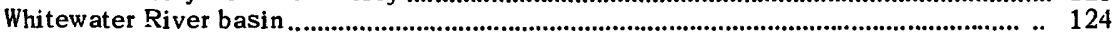

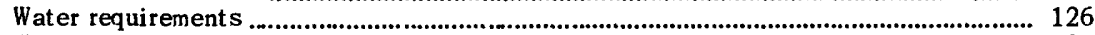

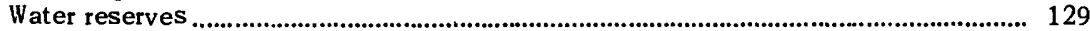

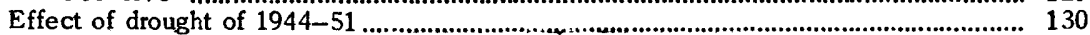

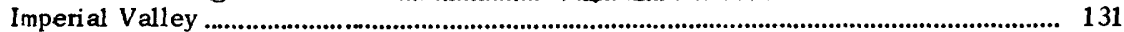

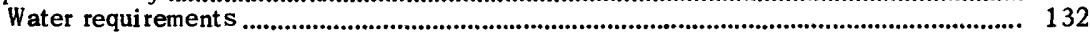

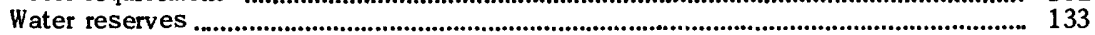


Imperial Valley-Continued

\section{ILLUSTRATIONS}

1. Index map showing regions covered in this report..

1. Index map showing regions covered in this report

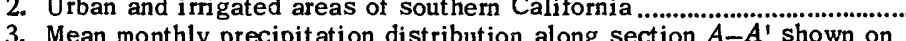
figure 2

4. Mean monthly temperature distribution along section $A-A^{\prime}$ shown on figure 2 .

5. Progressive 10-year mean annual precipitation at selected stations ......

6. Annual precipitation and its cumulative departure from mean .....................

7. Average annual precipitation and potential annual evapotranspiration distribution...

8. Annual growth of bigcone-spruce in southern California mountains

9. Annual runoff of the San Gabriel and Santa Ana Rivers

10. Area serviced by Metropolitan Water District of southern California .........

11. Relation between monthly precipitation and transpiration

12. Annual water importations to southern California

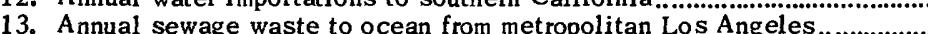

14. Population and annual water requirements of southern California

15. Map of the San Diego region showing valley fill, observation wells, and gaging stations

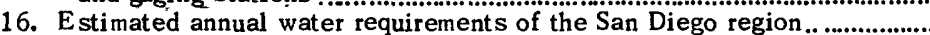

17. Annual runoff of San Luis Rey River and combined contents of surface reservoirs in San Diego region..

18. A nnual runoff of Santa Y sabel Creek and altitude of ground water at selected wells in San Diego region ..

19. Map of the Los Angeles region showing valley fill, observation wells, and gaging stations

20. Estimated annual water requirements of the Los Angeles region..............

21. Annual precipitation and runoff in the Los Angeles region........................

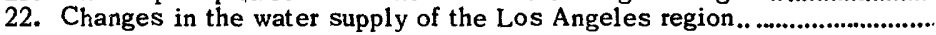

23. Contents of Big Bear Lake..

24. Annual runoff of the San Gabriel River and altitude of ground water at selected wells in the San Gabriel valley

25. Annual runoff of Santa Ana River and altitude of ground water at selected wells in the Upper Santa Ana Valley

26. Altitude of ground water at selected wells in the San Jacinto basin........

27 . Altitude of ground water at selected wells in the San Fernando Valley ..

28. Altitude of ground water at selected wells on the Coastal Plain.............

29. Map of the Ventura region showing valley fill, observation wells, and gaging stations

30. A nnual water deliveries to the city of Oxnard

31. Estimated annual water requirements of the Ventura region.

32. Annual runoff of Sespe Creek and altitude of ground water at selected wells in the Upper Ventura valley, the Ojai Valley, and on the Oxnard plain...

33. Annual runoff of Arroyo Las Posas and altitude of ground water at selected wells in the Simi, Las Posas, and Santa Rosa valleys

34. Map of Santa Barbara region showing valley fill, key observation wells, and gaging stations..

35. Annual water deliveries to the cities of Santa Barbara and Santa Maria.

36. Estimated annual water requirements of the Sant a Barbara region...........

37. Annual runoff of Santa Maria River and altitude of ground water at observation well in the Santa Maria valley 
Figure 38. Annual runoff of Santa Ynez River and altitude of ground water at selected wells in the Santa Ynez River valley

39. Altitude of ground water at selected wells in the Carpinteria and Golet a basins

40. Map of Antelope Valley basin showing valley fill, observation wells, and gaging stations

41. A nnual runoff of Rock Creek and Little Rock Creek and altitude of ground water at selected wells in the Antelope Valley

42. Map of Mojave River basin showing valley fill, observation wells, and gaging stations

3. A nnual runoff of Mojave River and altitude of ground water at selected wells in the Mojave River valley

44. Map of Whitewater River basin showing valley fill, observation wells, and gaging stations

45. Annual water deliveries to city of Palm Springs

46. Estimated annual water requirements of Coachella............................... 127

47. Altitude of ground water at selected wells in the Coachella Valley ........ 131

48. Annual water deliveries to the Imperial Valley ........................................... 133

49. Combined contents of Lake Mead and Lake Mojave..................................... 134

\section{TABLES}

Table 1. Cyclic distribution of annual precipitation

2. Disposal of average annual precipitation in certain southern California mountain areas.

3. Cyclic distribution of annual runoff

4. The occurrence of recent droughts in southern California ......................... 29

5. Value of irrigation water rights near San Bernardino, Calif., 1865-88 .... . 34

6. Annual consumption of electrical energy in the metropolitan areas of Los Angeles and Orange Counties

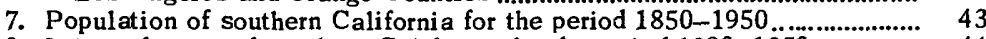

8. Irrigated areas of southern California for the period 1900-1950 ................. 44

9. Estimated annual water requirements for domestic and municipal purposes in southern California

10. Estimated irrigation water used in southern California

11. Storage capacity and purpose of reservoirs constructed between 1880 and 1950 .

12. Water imported into the San. Diego region from the Colorado River

13. Combined storage capacity of surface reservoirs in the San Diego region

14. Estimated annual recharge to the local water supply of the Los Angeles region.

15. Relation of local water reserves to water requirements in the Los Angeles region

16. Estimated mean annual runoff into Coachella Valley 


\title{
WsP $-1366 \quad(1957)$
}

\section{WATER RESOURCES OF SOUTHERN CALIFORNIA, WITH SPECIAL REFERENCE TO THE DROUGHT OF 1944-51}

\author{
By Harold C. Troxell
}

\begin{abstract}
Although favored with many desirable climatic features, the arid and semiarid valleys of southem California have experienced recurring dry periods throughout the ages. Records of tree-ring growth in the mountain areas for the last 560 years show that these dry periods range from 6 to more than 40 years in length. Consequently, nature has provided a drought-resistant plant cover which will not only exist in these arid and semiarid areas but will survive through recurring dry periods.
\end{abstract}

People have been attracted to southern California because of its favorable climate. The westward migration that began many years ago has resulted in a 1950 population of 5,650 , 000 , or about 3.7 percent of the nation's population. Almost 2,000,000 arrived in the area during the decade of $1940-50$ at an average rate of 542 persons a day.

With man came his need for water, both for domestic and for agricultural purposes. His water requirements exceeded the moisture provided by direct precipitation falling on the area. Consequently, it has been necessary to supplement the precipitation by use of ground water accumulated over the ages, flood runoff stored in mountain reservoirs, and water imported through long aqueducts from distant areas. The annual demand for supplement water has increased 11-fold, from 350,000 to $3,860,000$ acre-feet, in the 50 year period of $1900-50$.

During extended dry periods these ever-increasing demands for water have created critical conditions in the ground-water reserves and have completely drained many of the mountain reservoirs. In fact, in some areas, water became so scarce that the people reduced their water use, either through voluntary efforts or as a result of legislative action.

In the past 60 years, there have been three important periods of drought or water shortage; namely 1893-1904, 1922-34, and 1944-51. There is considerable uncertainty that the drought of 1944-51 was actually concluded in 1951. It is likely that time may demonstrate that this 7-year dry period was only a part of a much longer drought. During the latter part of each of these droughts, it was extremely difficult to obtain sufficient water for the crops and population of the area.

The drought of 1944-51 affected many of the water reserves in eight southern California regions. In some regions, such as the Imperial Valley and parts of San Fernando Valley, the effects of the drought were not evident. In contrast, some of San Diego County's largest reservoirs were drained, and in at least one instance wells were drilled in the dry reservoir bottom to develop the ground water that still remained. Over much of the area the ground-water reserves are the lowest in historical times. In the upland Ojai Valley the water levels at the index well declined more than 200 feet during the drought. In most other areas, the decline was less severe.

While the total decline in the local ground-water reserves during the drought of 194451 may not be significant in all the regions of southern California, the increase in the rate of decline is startling. This rate of decline increased from 3.1 feet per year during 
the 1922-34 drought to 9.9 feet per year during the 1944-51 drought at a key well in the San Gabriel valley, an area whose water resources are not generally considered as overdeveloped.

The drought of 1944-51 has clearly indicated that in much of the area the water reserves are overdrawn and that these areas may be subject to considerable distress unless the water requirements are reduced or the local water supplies are augmented by imported water. Furthermore, this overdtaft has so lowered the ground-water reserves in some coastal valleys that salt-water encroachment now exists or threatens.

The rapid increase in southern California's water requirements during recent years has made it progressively more difficult to satisfy all of man's needs. Even though the dry period of 1944-51 was not the most severe or longest drought in historical times, it probably created a greater adverse effect on the local water reserves than any preceding drought. The rapid increase in the rate of depletion of the local water reserves during successive dry periods should be viewed with considerable apprehension.

\section{INTRODUCTION}

On January 15, 1948, the City Council of Santa Barbara passed an emergency ordinance drastically restricting the use of water. This emergency ordinance was enacted "for the immediate preservation of public peace, health, and safety of the city of Santa Barbara [inasmuch as] "the sole source of water supply now available, because of the lack of rain and the hot weather, is not sufficient to last, at the present rate of consumption, until April 1st 1948 - the city of Santa Barbara faces a water shortage the gravity of which has never before been experienced in the history of the city" (City of Santa Barbara, 1948). This ordinance made it a misdemeanor punishable by a fine of $\$ 300$ or 90 days in jail or both (1) to sprinkle lawns or irrigate gardens, (2) to wash walks, courts, driveways or hard-surfaced areas, (3) to wash automobiles or any other vehicles, (4) to use water in ornamental or other types of fountains or pools.

Consequently, in order to protect the many valuable trees and shrubs in this coastal city, the propertyowners found it necessary to import water in tank trucks from less critical areas. One day earlier, January 14, 1948, the City Council of nearby Ventura (San Buenaventura) passed a similar ordinance (City of San Buenaventura, 1948). Thus the citizenry was rudely awakened to the fact that a drought existed and that their water resources were insufficient to satisfy all the requirements of these rapidly growing communities.

Farther south in San Diego County many of the reservoirs were dry or almost dry by the winter of 1951. El Capitan Reservoir, with a capacity of 116,000 acre-feet, had but 3,900 acre-feet in storage on December 1,1951 . With a combined capacity of about 93, 000 acre-feet, Morena and Barrett Reservoirs had only 550 acre-feet in storage on this same date. At Lake Henshaw, with a 
capacity of almost 204,000 acre-feet, the amount of water in storage had decreased to about 300 acre-feet by September 1951 . In fact, the water shortage became so acute that wells were drilled in the dry bed of this reservoir and water pumped into the small pool that still existed above the dam. As these water reserves dwindled, it became necessary to inaugurate very active conservation campaigns in an effort to reduce the water requirements.

By 1948 it was evident, even to the better supplied parts of southern California, that they were once again experiencing one of the periodic droughts that have visited this area throughout the ages. In fact, the precipitation and runoff records indicated that the drought actually began in the winter of 1944 .

\section{PURPOSE AND SCOPE}

The primary purpose of this report is to indicate the effect of the drought of 1944-51 on the water resources of southern California. At the time this analysis was begun, it was generally believed that the above-average precipitation of December 1951 and January and March 1952 may have concluded the drought that began in 1944. However, subsequent records show that 1951-52 was merely a single wet year in a continuing period of drought. Consequently, the period of $1944-51$ of this report represents only the first part of a longer drought still being experienced during 1955.

This drought was not confined exclusively to southern California but extended throughout the entire arid and semiarid regions of the Southwest, including all or parts of Arizona, Nevada, Utah, New Mexico, Colorado, Texas, and Oklahoma, (U. S. Dept. Interior, 1951), and it still persists in many of these areas.

In chronicling the effects of the drought of 1944-51 on the water resources, this report will be limited to that part of southern California outlined on figure 1. This 25,000-square-mile area includes all or part of Santa Barbara, Ventura, Los Angeles, Orange, San Bernardino, Riverside, San Diego, and Imperial Counties and represents about 16 percent of the land area in the State of California. To facilitate the analysis, it has been divided into eight units, designated as the

San Di ego region

Los Angeles region

Ventura region

Santa Barbara region

Antelope Valley basin

Mojave River basin

Whitewater River basin

Imperial Valley 


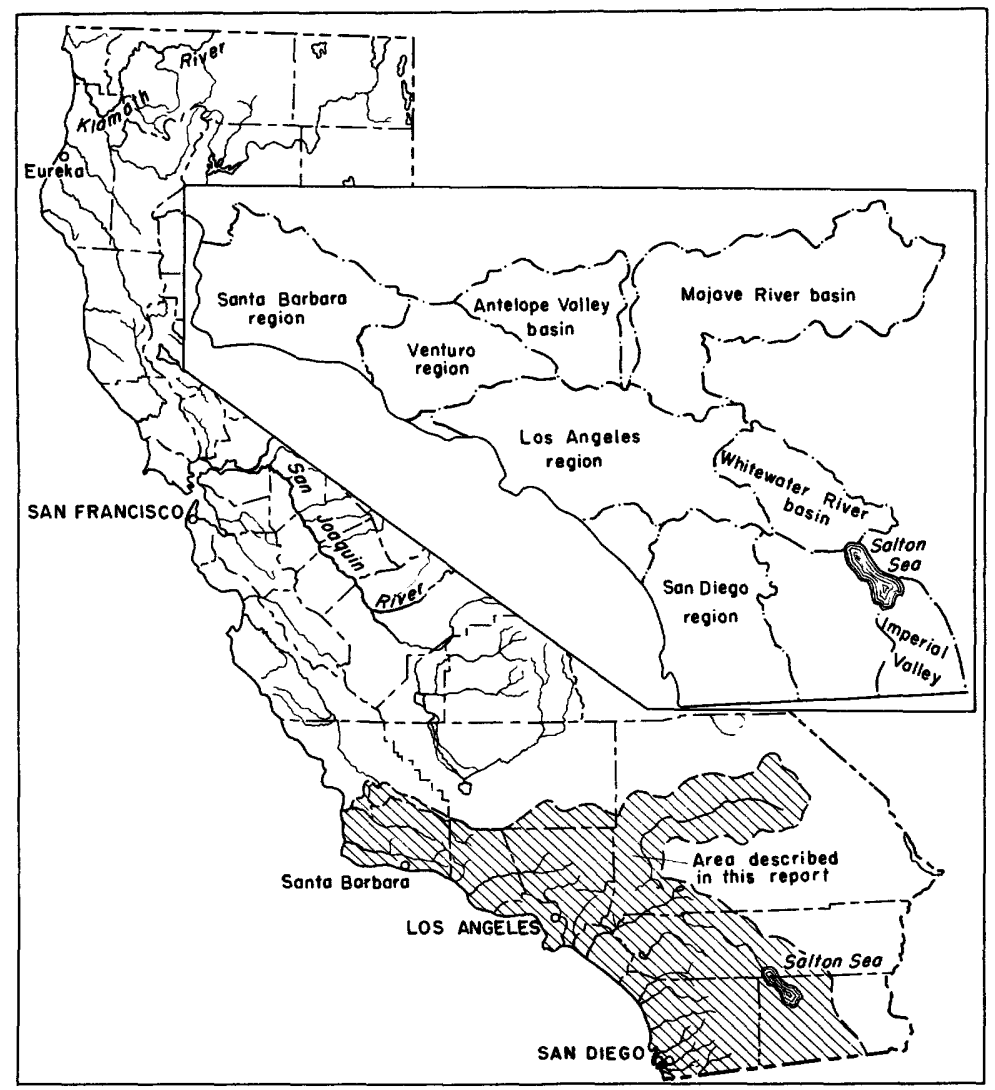

Figure 1. - Index map showing regions described in this report.

The locations of these eight units are shown on the inset map on figure 1.

More than 50 percent of the State's population of $10,600,000$ live in this area. For that reason, the principal urban areas are sketched on the map of figure 2. The greatest concentration of population is in the Los Angeles metropolitan area. Here some of the richest agricultural lands in the State have been converted to urban and suburban use. The second greatest concentration of population is in the more southerly San Diego metropolitan area. Because of climatic considerations, most of these urban developments have been in the coastal regions.

In contrast, the greatest single unit of agricultural land in the area, the Imperial Valley, is in the desert region. These irrigated lands, just north of the Gulf of California, amount to about 8 percent of the State's total under irrigation. The distribution of these irrigated lands is also shown on figure 2. 


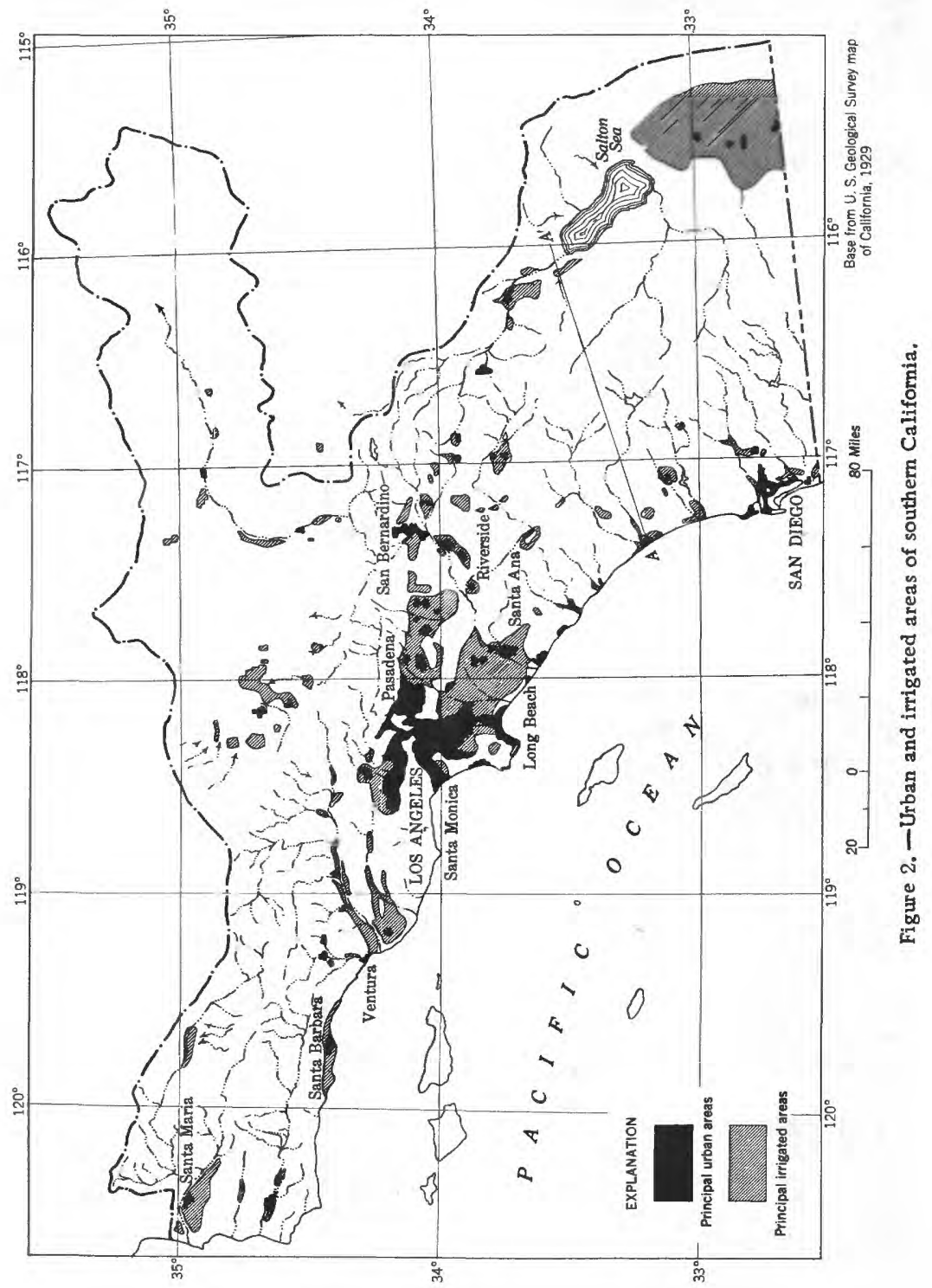




\section{WSP -1366}

The 1950 census shows that the crops from the eight southern California counties account for 31 percent of the State's agricultural income. Although it is the most populous of the southern California counties, Los Angeles County produced the greatest agricultural wealth in 1951, a crop valued at $\$ 243,000,000$ (Los Angeles County Board of Supervisors, 1952). Riverside County was second, with a 1951 crop value of $\$ 124,000,000$, and Imperial County third with a crop value of $\$ 109,000,000$. The total value of crops produced in these eight counties in 1951 amounted to $\$ 900,000,000$.

\section{ACKNOWLEDGMENTS}

The author is indebted to many water companies, water dis tricts, and municipal water departments for data used in the preparation of this report, and he is pleased to acknowledge the capable assistance of Harry D. Wilson, Jr., and Walter Hofmann in preparing and reviewing the text. Acknowledgment is also due to the many others who have reviewed the text and made suggestions for its improvement and modification.

\section{WHAT CONSTITUTES A DROUGHT?}

A drought has been broadly defined by Webster as a "want of rain or of water." Actually a drought may be interpreted as meaning a persistent want of soil moisture in the root zones of the native plants or agricultural crops whether it be due to lack of current rainfall or to insufficient water reserves.

This is largely in accord with the following definition by J. C. Hoyt (1936, p. 2):

When in an area that is ordinarily classed as humid, natural vegetation becomes desiocated or defoliates unseasonably and crops fail to mature owing to lack of precipitation, or when precipitation is insufficient to meet the needs of established human activities, drought conditions may be said to prevail. Although water for irrigation or other uses in arid areas is always limited, special shortages in such areas are also re garded as droughts.

As interest in droughts may relate either to their physical characteristic as determined by the phenomena which cause them or to their economic effects as reflected by damage, they may be considered either as natural phenomena or as economic phenomena-usually both-and it is therefore essential in drought studies to take into account not only physical data but also information as to the extent and nature of human activities in the area affected.

W. G. Hoyt (1942, p. 580) states that:

In connection with present-day activities of a highly-organized civilization, it is there fore increasingly difficult to define and delineate droughts on the basis of a study of meteorological and hydrological conditions alone. 
Often, it has been the economic factors that most generally determine the existence of a drought: the parched fields and ruined agricultural crops, the undernourished livestock, depressed crop or land values, and general want and unemployment in the agricultural areas.

In many of the more humid areas the local precipitation is generally the immediate origin of the moisture in the root zone of the agricultural crops, while in the more arid areas the immediate origin of this soil moisture is irrigation water obtained from surface and ground-water reservoirs. In the arid and semiarid West, the local precipitation is not sufficient to mature the usual agricultural crops upon which man is dependent. To make his venture a success, the water user must develop surface reservoirs that store the excessive flood runof, tap and efficiently utilize the ground-water reserves, and build aqueducts to distant areas of water surplus. It is largely the failure of these supplemental sources that brings want and hardship to the western water user. Generally, the failures in these supplemental sources coincide with periods of deficient precipitation.

Except for a few isolated areas, there was little or no want and no loss of crops in southern California during the drought of 1944-51. In fact, most of the urban dwellers were unaware of water shortage. The only evidence to indicate occurrence of a drought was to be found in the grossly depleted surface-and ground-water reserves.

To the city dweller, as well as to the agriculturist, a drought exists whenever he is required to reduce his water uses. In light of the foregoing definitions, the frequency of a drought will depend largely on the amount of the water reserves in relation to the region's annual water requirements. If these reserves are large in terms of the water requirements, then many a period of deficient precipitation may pass without any curtailment of the water requirements, and the droughts may go unnoticed as meteorological phenomena. However, there are many less fortunate areas where the reserves are small in terms of the water requirements. In these areas each such period of deficient precipitation is recognized as a drought.

In an area as large and complex as southern California, there may be several examples of each extreme and many variations in between. Consequently, in parts of this area the current drought has been almost unnoticed, while in other parts the reserves were the lowest within historical times.

In determining the severity of this drought it has been necessary, as suggested by J. C. Hoyt (1936), to study both the 
meteorological and hydrological factors, and the water requirements of the inhabitants. The severity of the drought is then represented by the combination of these two factors. This pattern of procedure is fairly closely adhered to throughout the rest of this analysis.

\section{HYDROLOGIC FACTORS}

Man's successful occupancy and development of the arid and the semiarid regions of southern California will always depend on a large amount of vision and perseverance, associated with technically sound and well-organized planning. Any other conception would lead to privation and want. Orderly planning is necessary, because the precipitation throughout most of the area is insufficient to satisfy all man's water requirements. The almost complete lack of summer precipitation precludes the type of agricultural crops upon which he is locally dependent, unless supplemental water can be had. To obtain sufficient supplemental water requires the prudent and efficient use of all the existing water reserves, both surface and subsurface.

The continually growing complexity of each of these water reserves and their interrelations have made it essential for the water users fully to understand many of the more important hydrologic factors. The most important hydrologic factor sustaining these water reserves is the polar Pacific air mass originating over the Arctic seas and over the Arctic and subarctic interiors of Siberia and Alaska. After traveling by devious routes over the warm Pacific Ocean where it absorbs considerable moisture, the air mass moves eastward through California and other western coastal States. This moisture is temporarily stored in the air mass as water vapor until circulation, resulting from the mixing of air having unequal temperatures or the forced lifting by prevailing winds over the coastal mountains, causes it to condense and to precipitate as rain, snow, or dew. On reaching the ground surface the major part of this precipitation enters the mantle rock as soil moisture, with the residual moving over the ground surface as runoff. This soil moisture reserve is probably the best distributed and most frequently recharged of all the water sources in southern California.

\section{CLIMATE}

Climate is the result of the world-wide circulation of the earth's atmosphere and is governed by a complex relationship among such meteorological phenomena as precipitation, temperature, 
humidity, sunshine, sky cover, and wind. This interrelationship governs the types and character of the plant cover and creates an environment which may, or may not, be suitable for human occupation. However, through man's ingenuity, certain unfavorable climatic factors have been overcome so that his food supply and bodily comforts are satisfied in areas formerly believed to be unsuited for human habitation. In such areas man is very conscious of any or all of these climatic factors which may affect his wellbeing. This is particularly true in southern California where most of the area is arid or semiarid.

To facilitate this analysis of climate, the area can be broadly divided into coastal, mountain, and desert on the basis of physiographic features.

\section{CoAstaL AREA}

The coastal area is defined as the long narrow belt of plain and valley floor on the oceanward side of the coastal, transverse, and peninsular ranges. Climatologists and geographers have classified the climate of this coastal area as Mediterranean because of its mild winters of limited precipitation and its dry and warm summers.

The monthly precipitation distribution is shown. on figure 3 for a few key stations along a cross section $A-A^{\prime}$ extending from Oceanside in San Diego County to a point 100 miles inland just beyond the Little San Bernardino Mountains in Riverside County. The precipitation distribution shown here for Oceanside and Fallbrook is typical of the records obtained in the entire coastal belt extending from San Diego to Santa Maria. In this belt the precipitation distribution is characterized by a single rainy period generally extending from November through April. More than 90 percent of the average annual precipitation of 10 to 20 inches falls in this 6-month period. January and February are generally the wettest months and each has an average precipitation of 3 to 4 inches.

The winter rains are followed by an annual summer dry period in which there is no soil moisture replenishment for the support of the plant cover. As a result of dry summers, the native vegetation is of a dwarf and drought-resistant nature, which grows and flowers in the winter and spring months and becomes dormant in the summer.

As another important climatic factor is temperature, the mean monthly temperature distribution at a few key stations is shown on figure 4. These stations are located along the same cross 


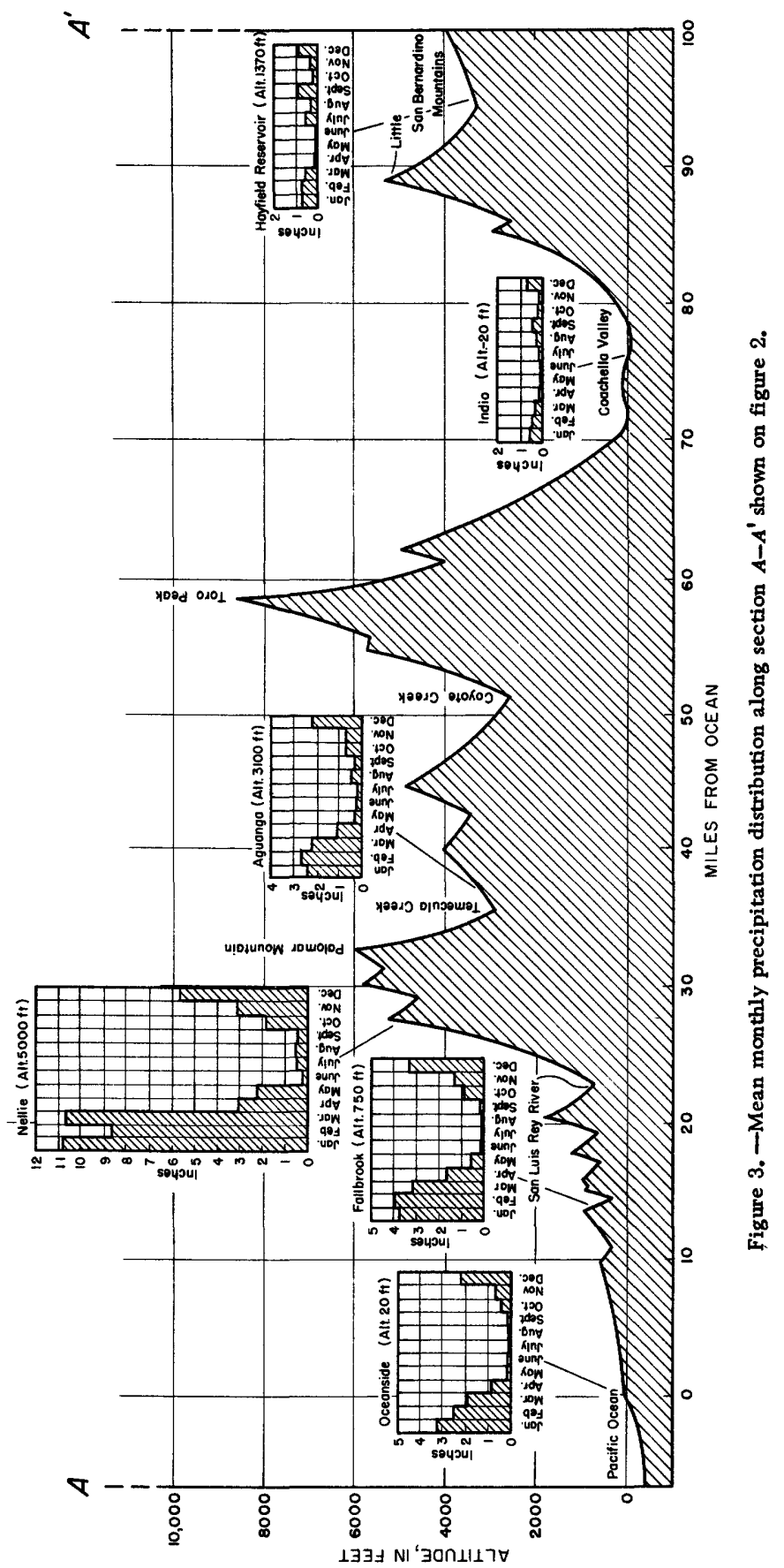




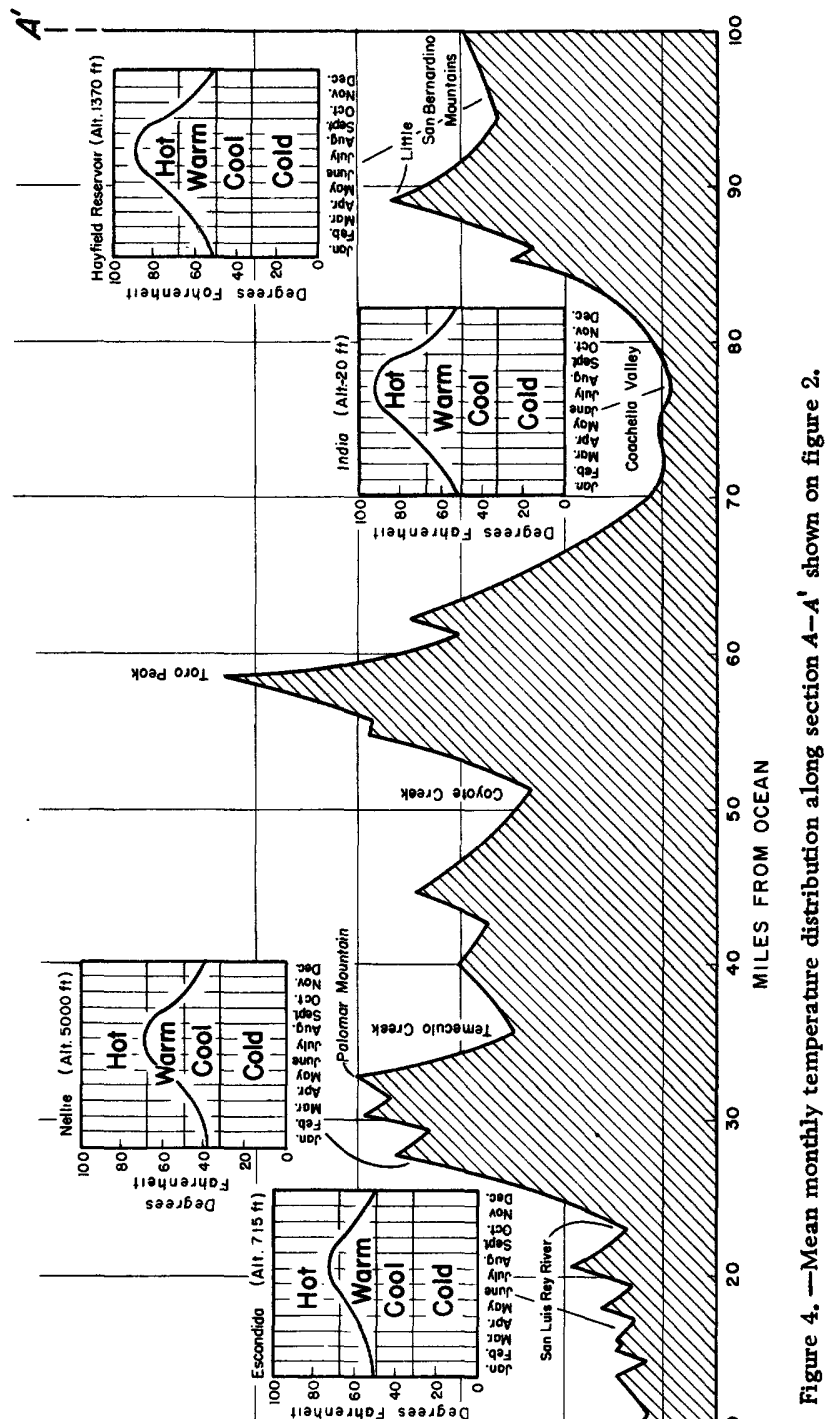


section used in the preceding diagram. In recent years climatologists have generally classified monthly temperatures as hot, warm, cool, and cold. On this basis, monthly temperatures in excess of $68^{\circ} \mathrm{F}$ are considered as hot, those ranging from $50^{\circ}$ to $68^{\circ} \mathrm{F}$ as warm, those ranging from $32^{\circ}$ to $50^{\circ} \mathrm{F}$ as cool, and those below $32^{\circ} \mathrm{F}$ as cold. As indicated by the Oceanside and Escondido records, the temperatures in the coastal belt are continuously warm and become slightly hot in the summer months. The complete range in monthly temperature is limited to about $15^{\circ}$ to $20^{\circ}$ because of the modifying influences of the Pacific Ocean.

Another of the more important climatic factors is humidity. It exerts a major influence on comfort of the human body and the water requirements of plants. Under the influence of high air temperatures plant life, like the human being, transpires to reduce its temperature. As a result, the evaporation of this moisture has a cooling effect on the adjacent air temperature. The magnitude of this evapotranspiration is controlled in part by the amount of moisture in the air. As the humidity increases and the air becomes more nearly saturated with moisture, the evaporation and transpiration processes become greatly retarded.

The most common index of humidity is the relative humidity. Relative humidity represents the amount of water vapor actually present in the air, compared with the maximum that could be retained under the same conditions of temperature and pressure. Records obtained at San Diego are believed to reflect fully the relative humidity conditions throughout the coastal belt. The relative humidity at this station ranges from about 68 percent in midwinter to 78 percent in midsummer, and the annual average is 73 percent (U. S. Weather Bureau, 1951). This is comparable to the average annual relative humidity of 68 percent at Los Angeles and 74 percent at Santa Maria. These relative humidity values generally exceed similar data obtained over most of southern California. As a consequence of this high humidity, opportunity for evapotranspiration, resulting from the climatic factors govering plant life, and water requirements should be at a minimum.

Even under these conditions of high humidity, the potential evapotranspiration of the native plant cover exceeds the annual precipitation. Consequently the climate of the coastal region has been designated as semiarid, in conformity with methods proposed by Thornthwaite (1931).

\section{MOUNTAIN AREA}

The mountain area is loosely defined as including all the coastal ranges extending from the San Rafael Mountains in the north to 
the Laguna Mountains in the south, and includes some of the most rugged country in California. These mountains exert considerable influence over the areal distribution of the precipitation. In response to the usual air circulation, the precipitation will generally be greatest on the windward side of the range and least on the leeward side.

In the cross section on figure 3 , the Palomar Mountains are representative of the mountain area. On the windward side of this range the average monthly precipitation near the frontal divide approaches 11 inches during the months of January and March at Nellie. As in the coastal areas, about 90 percent of the annual precipitation falls in the 6 -month period of November through April. This is believed to be typical of the monthly precipitation distribution throughout the entire mountain area.

This winter rainfall period is followed by the annual summer dry period. As a consequence, large areas of the mountains are covered with drought-resistant plants which becomes dormant during the summer.

Because of the higher altitude in the mountain area, the temperatures are generally cooler, as indicated by the record obtained at Nellie (Fig. 4). At this station the temperatures range from cool in the winter to warm in the summer. In winter, the mountains are significantly colder than the coastal belt, but in summer there is little difference. A range in monthly temperatures of about $30^{\circ}$ is to be expected in most southern California mountains.

Relative humidity readings have been made at Palomar Mountain for several years, but the data have not been summarized nor are they in a form readily adaptable to this report. For that reason the data obtained at Mount Wilson north of Los Angeles and Pasadena have been substituted. The average monthly relative humidity at this station ranges from 61 percent in March to 31 percent in July, and its annual average is 46 percent. This relative humidity is from 20 to 30 percent less than that in the coastal areas. As a consequence, water loss by evapotranspiration would be greater here were it not for the adverse effect of the lower air temperatures. Because the potential water requirements of the native plant cover are less than the precipitation in some of the mountain areas, the climate has been designated humid or subhumid by Thornthwaite (1948).

\section{DESERT AREA}

All of southern California on the leeward side of the coastal mountain area is desert. It includes the vast Mojave, or upper, 
Desert, and the lower and warmer Colorado Desert. These arid regions represent an area of about 30,000 square miles, or about two-thirds the area of New York State. Climatologists have classified the climate of this region as subtropical desert.

These desert regions are areas of continuous aridity where the average annual precipitation seldom exceeds 5 or 6 inches. The average monthly precipitation records obtained at the Indio and Hayfield Reservoir stations are shown on figure 3 as representative of the desert area. Because of the general dryness, the range of precipitation between winter and summer is less than in the coastal and mountain areas. Because of cloudless skies, the desert area has the highest summer temperatures, although in winter the temperatures do not differ greatly from those observed in the coastal area. The records obtained at Indio and Hayfield Reservoirs, and used in preparing figure 4 , show the typical temperature distribution of the desert. In these areas the monthly temperatures range about $40^{\circ}$ from the minimum of the warm classification in midwinter to hot in midsummer.

Low relative humidities are of course to be expected in these regions of aridity. Records obtained at Yuma along the Colorado River show the driest air conditions: average monthly relative humidity ranging from about 30 to 50 percent, and an average annual value of 40 percent.

This lack of humidity and the generally higher temperatures greatly increase the opportunity for evapotranspiration over that experienced in the coastal and mountain areas. Climatically, the area is classified as arid because the opportunity for the evapotranspiration greatly exceeds the precipitation.

\section{CHRONOLOGICAL DISTRIBUTION OF PRECIPITATION}

Of the water reserves available to the area, those originating in southern California are completely dependent upon the magnitude and variability of the local precipitation for sustenance. Most of this precipitation has its origin in the polar Pacific air masses which move inland through British Columbia, Washington, Oregon, and California, with the southern fringe passing through southern California. As a result of this distribution, the average annual precipitation along the coast of California declines from 53 inches at Crescent City in the north to 10 inches at San Diego in the south.

If this precipitation distribution were of a purely random nature, one could expect the wet and dry years to alternate at frequent intervals. But such is not the case. In the past 80 to 100 years, there have been periods of 5 to 20 consecutive years when 
the annual precipitation was either almost continuously below or above normal.

This definite cyclic trend probably is best illustrated by the graph of 10-year means shown on figure 5. Each plotted point on

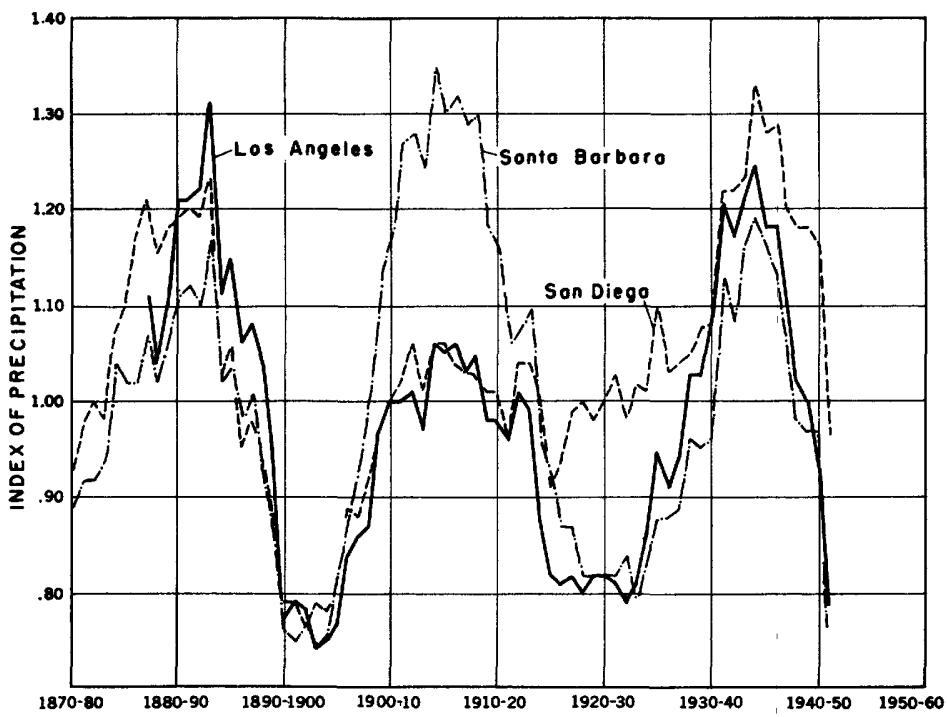

Figure 5. -Progressive 10-year mean annual precipitation at selected stations.

this graph represents the mean annual precipitation for a 10-year period at the Los Angeles, Santa Barbara, or San Diego stations. (Throughout this report the annual precipitation is based upon the climatological year of July 1 to June 30.) The vertical scale of this graph gives the ratio of the mean annual precipitation for the 10 -year period to the mean annual value for the entire period of record.

The graphs on this diagram show three extended wet periods, two completed dry periods, and one probably incomplete dry period.

These diagrams emphasize the extreme variability in the time distribution of the precipitation. These records are equally representative of the time distribution in the recharge to the local water reserves. They show that there will be extended periods when the recharge will be above normal and equally extended periods when the recharge will be below normal.

The graphs indicating the cyclic tendency of extended wet and dry periods (fig. 5) do not show the actual beginning and ending of 
these periods. These termini can be demonstrated by plotting the cumulative departures of the individual annual values from the mean for the period of record. The cumulative departures of these annual values since the beginning of record are shown on figure 6 for Los Angeles in the coastal area and Cuyamaca in the mountain area.

\section{COASTAL AREA}

The upper part of figure 6 gives the chronological distribution of the annual precipitation at Los Angeles for the 74-year period of 1877-1951. The extreme variability of the annual precipitation and its roughly cyclic distribution are readily recognized. Within this period the annual precipitation has ranged from 5.59 inches in 1898-99 to 38.18 inches in $1883-84$, with a mean value of 15.06 inches.

The 8 driest years have been indicated by numbers on figure 6 , in descending order of dryness, to emphasize the sequence of the drier years. Three of these unusually dry years occurred in the 3-year period of July 1, 1897 to June 30, 1900. This period was preceded 3 years earlier by the third driest year in the entire period of record. The four remaining unusually dry years occurred in the 2-year sequences of July 1, 1923 to June 30, 1925 and July 1, 1947 to June 30, 1949.

The lower part of figure 6 gives the cumulative departures of the annual precipitation at Los Angeles in percent from the 74year mean annual value: A plus departure indicates the magnitude by which the precipitation exceeds this mean, and a negative departure gives the magnitude by which the precipitation was less than this mean. Consequently, upward trends in this graph represent a period of time in which the precipitation was above the average. Likewise, downward trends represent a period of belowaverage precipitation.

At certain points within this 74-year period there is a definite change in trend. These points represent the beginning and ending of alternate wet and dry periods. On the basis of this distribution, the record contains three completed wet periods and two completed dry periods; with the final period of July 1, 1944 to June 30,1951 representing an incomplete dry period. In summarizing these wet and dry periods in table 1, it has been assumed that the final period represents a completed dry period. This table gives the date and length of alternating wet and dry periods, the average annual precipitation for each period, and the departure of these averages from the 74-year mean. Averages 

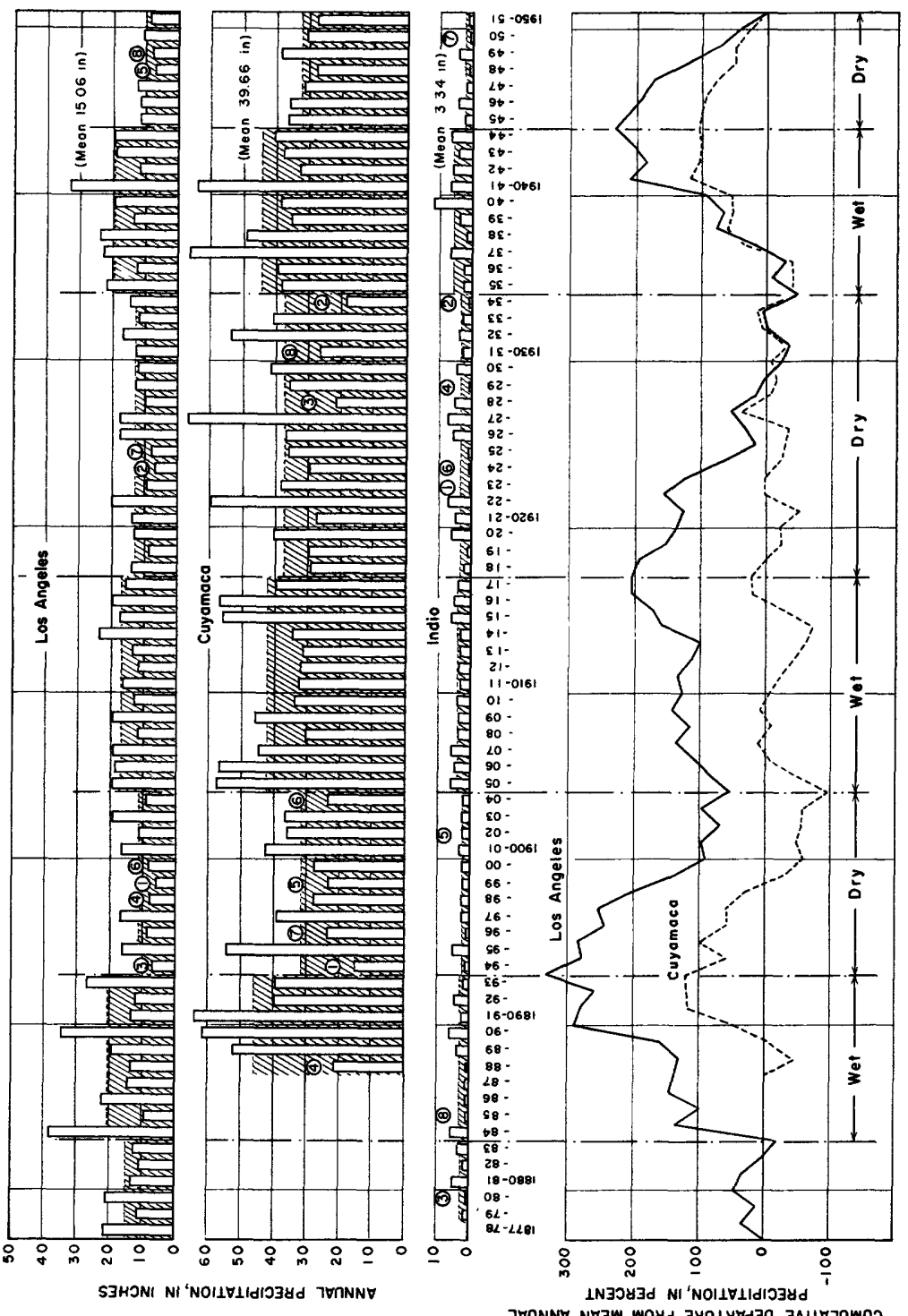
Table 1.-Cyclic distribution of annual precipitation

\begin{tabular}{|c|c|c|c|c|c|c|c|c|}
\hline \multirow[b]{2}{*}{ Date } & \multirow[b]{2}{*}{$\begin{array}{c}\text { Character } \\
\text { of } \\
\text { period }\end{array}$} & \multirow[b]{2}{*}{$\begin{array}{c}\text { Length } \\
\text { of } \\
\text { period } \\
\text { (years) }\end{array}$} & \multicolumn{2}{|c|}{ Los Angeles } & \multicolumn{2}{|c|}{ Cuyamaca } & \multicolumn{2}{|c|}{ Indio } \\
\hline & & & \begin{tabular}{|c|} 
Annual \\
mean \\
of \\
period \\
(inches)
\end{tabular} & \begin{tabular}{|c|} 
Departure \\
from \\
$74-$ year \\
mean \\
(percent)
\end{tabular} & $\begin{array}{c}\text { Annual } \\
\text { mean } \\
\text { of } \\
\text { period } \\
\text { (inches) }\end{array}$ & \begin{tabular}{|c|} 
Departure \\
from \\
64 -year \\
mean \\
(percent)
\end{tabular} & \begin{tabular}{|c|} 
Annual \\
mean \\
of \\
period \\
(inches)
\end{tabular} & \begin{tabular}{|c} 
Departure \\
from \\
$73-$ year \\
mean \\
(percent)
\end{tabular} \\
\hline 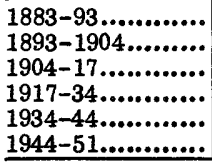 & $\begin{array}{l}\text { Wet } \\
\text { Dry } \\
\text { Wet } \\
\text { Dry } \\
\text { Wet } \\
\text { Dry }\end{array}$ & $\begin{array}{r}10 \\
11 \\
13 \\
17 \\
10 \\
7\end{array}$ & $\begin{array}{r}20.32 \\
11.24 \\
16.78 \\
12.80 \\
19.32 \\
9.99 \\
\end{array}$ & $\begin{array}{l}+35 \\
-25 \\
+11 \\
-15 \\
+28 \\
-34\end{array}$ & $\begin{array}{l}46.42 \\
31.88 \\
42.37 \\
37.13 \\
44.27 \\
32.55 \\
\end{array}$ & $\begin{array}{r}+17 \\
-20 \\
+7 \\
-6 \\
+12 \\
+18 \\
-18\end{array}$ & $\begin{array}{l}2.73 \\
2.16 \\
3.84 \\
3.14 \\
5.08 \\
2.11 \\
\end{array}$ & $\begin{array}{r}-18 \\
-35 \\
+15 \\
-6 \\
+52 \\
-37 \\
\end{array}$ \\
\hline
\end{tabular}

of the periods are superposed on the annual records in the upper part of figure 6 to emphasize the roughly cyclic distribution of the precipitation.

In the 10-year wet period of 1883-93 (table 1) the mean annual precipitation at Los Angeles was 20.32 inches, or 35 percent greater than the 74-year mean. Although this period is considered to. be predominantly wet, fully half of the years had less than the 74 -year mean annual precipitation.

This wet period was followed by an 11-year dry period in which the average annual precipitation was 11.24 inches, or 25 percent less than the 74-year mean. This dry period was one of the worst in modern times. As shown on figure 6, its 11 years include 4 of the 8 driest years in the entire period of record, but they also include 4 years in which the annual precipitation exceeded the 74year mean.

Of the three predominantly dry periods listed in table 1 , the last one that of 1944-51-was the shortest and the driest in the entire period of record at Los Angeles.

\section{MOUNTAIN AREA}

The second record shown in the upper part of figure 6 gives the annual precipitation distribution at Cuyamaca, situated in the Cuyamaca Mountains of San Diego County. This 64-year record was selected largely because of its length and because it represents the precipitation in that relatively small part of southern California classified as humid or subhumid. The precipitation at this site tends to reflect the same extreme variability observed at Los Angeles, with the annual precipitation ranging from 15.05 inches in 1893-94 to 66.55 inches in 1926-27, and having a 64year annual mean of 39.66 inches. 
As at the Los Angeles station, the 8 driest years have been designated in descending order of dryness. It will be noted that there is considerable difference between the sequence of these events at Los Angeles and Cuyamaca, but this merely reflects the variability in precipitation that of ten exists from station to station. In fact, only 2 among the 8 driest years at these 2 stations were identical.

The graph of cumulative departures for the Cuyamaca record (lower part of fig. 6) shows less positive trends or change in trends. Consequently, the distribution by periods as recorded at Los Angeles is assumed to be the same at this station.

Table 1 gives the average annual precipitation by periods and its departure from the 64-year mean for each wet and dry period. Each of these periods is shown in pattern on the Cuyamaca record in the upper part of figure 6.

The first dry period, containing 4 of the 8 driest years, and extending from July 1, 1893 to June 30, 1904, was the driest in the entire period of record. This 11-year period, however, included 1 year-1894 to 1895 - in which the annual precipitation was 54.78 inches, 28.43 inches occurring in the single month of January 1895.

The relatively short current drought period of 1944 to 1951 is the second driest period in the 64-year record although none of the 8 driest years fell within it.

\section{DESERT AREA}

The concluding record shown in the upper part of figure 6 is that obtained at Indio, about 20 feet above sea level in the Coachella Valley of the Colorado Desert. The principal importance of this 73 -year record is to show the continuous aridity in these desert regions. The annual precipitation ranges from 0.18 inch in 192223 to 11.50 inches in $1939-40$, with a mean of 3.34 inches. In the wet year of $1939-40,6.78$ inches of the 11.50 inches fell during severe tropical storm of September 24-25, 1939 (Hurd, 1939, p. 356-358).

As with the preceding stations, the 8 driest years have been indicated. Although there is little relation between the precipitation observed at this and the two preceding stations, 7 of the 8 driest years occurred in recognized dry periods. 


\section{WATER REQUIREMENTS OF NATIVE VEGETATION}

Every living thing requires water for survival. Furthermore, in the arid and semiarid regions there is keen competition for all the available water. In this competition, plant life has the advantage of being able to utilize soil moisture, which is the most readily available and best distributed form of water reserve.

Before the coming of the early settlers, only the native plant life competed for this soil moisture. This competition has developed a type of plant life that ranges from the cottonwoods and sycamores in the cienagas (springs and surrounding marshy area) of the valleys to the drought-resistant chaparral of the mountain and foothill areas and the desert shrubs of the arid areas. The droughtresistant plants are extremely tole rant, consuming large quantities of water if available, or existing on a mere pittance, if necessary.

\section{POTENTIAL EVAPOTRANSPIRATION}

In those parts of southern California not occupied by urban or irrigated lands (see fig. 2), native vegetation and evaporation from land area consume practically all of the precipitation that enters the root zone, except in the higher mountain areas, where greater precipitation occurs. The amount of moisture which native, as well as cultivated, crops will consume depends on the available moisture and the local evapotranspiration potential. The local evapotranspiration potential is the resultant of a complex array of those energy-furnishing and distribution factors of solar radiation, temperature, wind, and humidity.

Thornthwaite (1948) using evapotranspiration data about native vegetation and irrigated crops developed an empirical formula relating potential evapotranspiration to temperature and computed potential annual evapotranspiration for various areas in the United States. Making use of lysimeters or soil-moisture analyses, similar observations have been made of irrigated crops in southern California by Blaney, Taylor, Beckett, Pillsbury, Muckel, and many others, all of which have been summarized by Young (1945). By use of these observations and Thornthwaite's maps, the potential annual evapotranspiration is given on figure 7 for a cross section extending from Oceanside to Little San Bernardino Mountains.

Probably nowhere else in the United States is there so wide a range in the average annual potential evapotranspiration in such short distances as in southern California. Average annual potential evapotranspiration (fig. 7) decreases from about 36 inches 

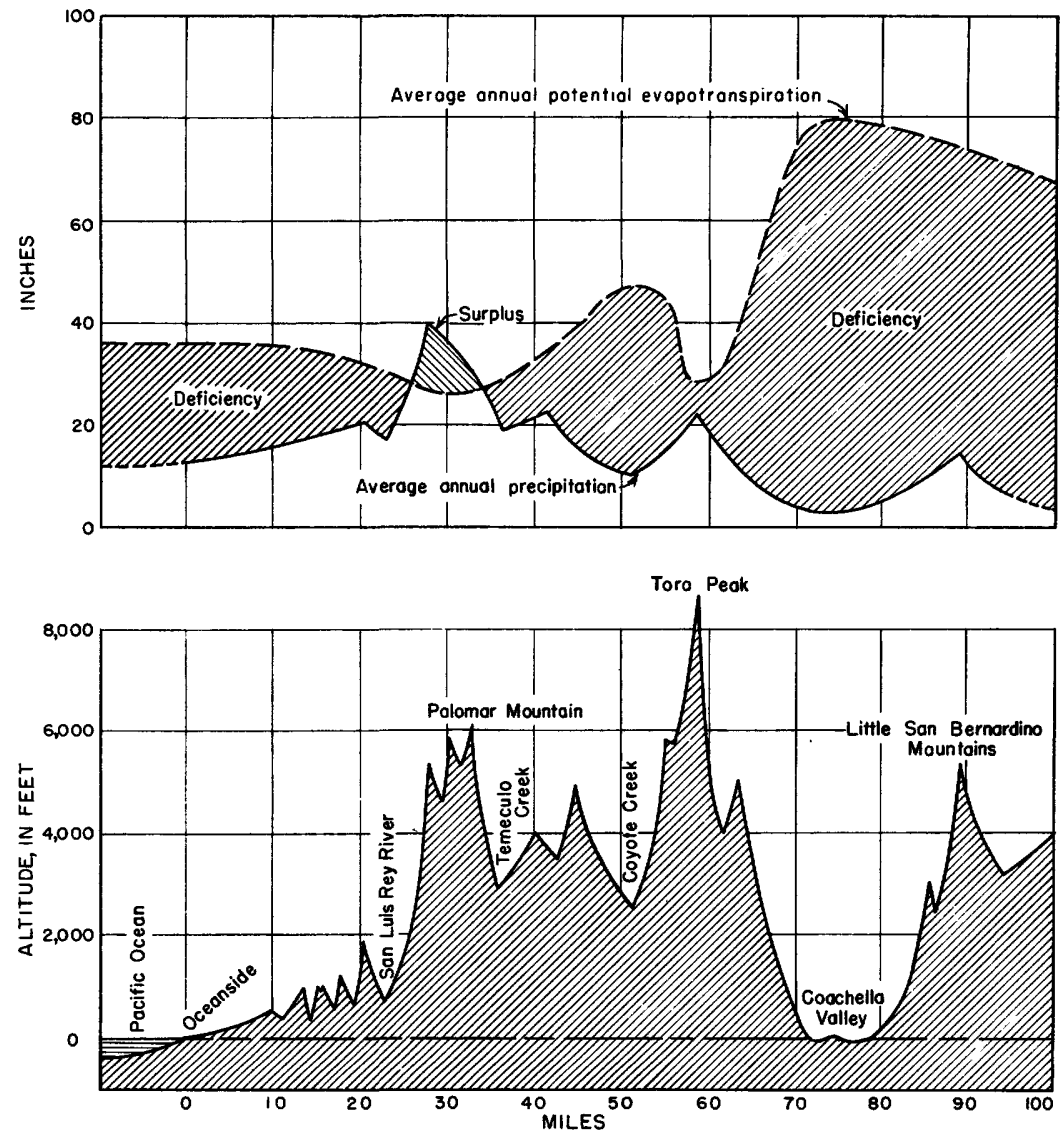

Figure 7. - Average annual precipitation and potential annual evapotranspiration distribution.

along the coast to 26 inches near Palomar Mountain, 30 miles inland. This decrease is believed to be due to lower temperatures inland. At 50 miles from the ocean in the arid Coyote Creek region the potential is believed to increase to 47 inches because of a higher temperature and a lower relative humidity. Still farther from the ocean and on the leeward side of Toro Peak in the arid Coachella Valley it increases to almost 80 inches. Consequently, the average annual potential water requirements in the 100-mile cross section of figure 7 will range from 26 to 80 inches, depending on the locality.

Figure 7 also shows the areal distribution of the average annual precipitation, which is a measure of the moisture availability. Annual precipitation increases from an average of about 12 inches at Oceanside to 40 inches on the windward side of the Palomar Mountains, then decreases to about 10 inches near Coyote Creek. 
On the leeward side of Toro Peak the average annual precipitation further decreases to about 3 inches in the Coachella Valley.

It is evident from these two curves that the local precipitation cannot provide all the moisture required to satisfy completely the potential annual evapotranspiration. In fact, a moisture surplus exists only in that small part of the cross section in the vicinity of the Palomar Mountains. This and similar moisture surpluses found in the mountains of southern California are one of the main sources of recharge to the water resources.

\section{ANNUAL WATER CONSUMPTION}

As already indicated, the amount of water consumed annually by the plant cover will depend upon the opportunity for evapotranspiration, and upon the moisture available. In most mountain and valley floor areas this combination will vary considerably from year to year at the same site.

Research has demonstrated that under certain conditions the annual tree growth of such crops as the bigcone-spruce in the mountains of southern California reflects the magnitude of the amount of water consumed. Schulman (1947) in his research in the San Gabriel, San Bernardino, San Jacinto, and Palomar Mountains of southern California found more than 50 suitable bigconespruce from which he was able to produce an index of tree growth for the last 560 years. This unusually long record started in 1385, about 157 years before Cabrillo first sailed along the California coast.

These records are given on figure 8 in the form of a graph showing the cumulative departure expressed as a percent of the average annual tree-ring growth for the period 1385 to 1944 . When the annual growth exceeds the average, the departure will be positive and the curve will rise; when the annual growth is less than the average, the departure will be negative and the curve will fall. These cumulative values show the same cyclic tendencies as do the precipitation record. The beginning and ending of each of these above- or below-normal periods of tree growth have been indicated on the graph. Periods of subnormal growth have been crosshatched on the diagram for purposes of contrast.

These trees were carefully selected in areas of marginal precipitation where the only moisture available to the root system was from precipitation. Under these conditions the tree's total water requirements were seldom completely satisfied. Thus annual tree growth becomes an index of precipitation, and as such shows the sequence of wet and dry periods. 


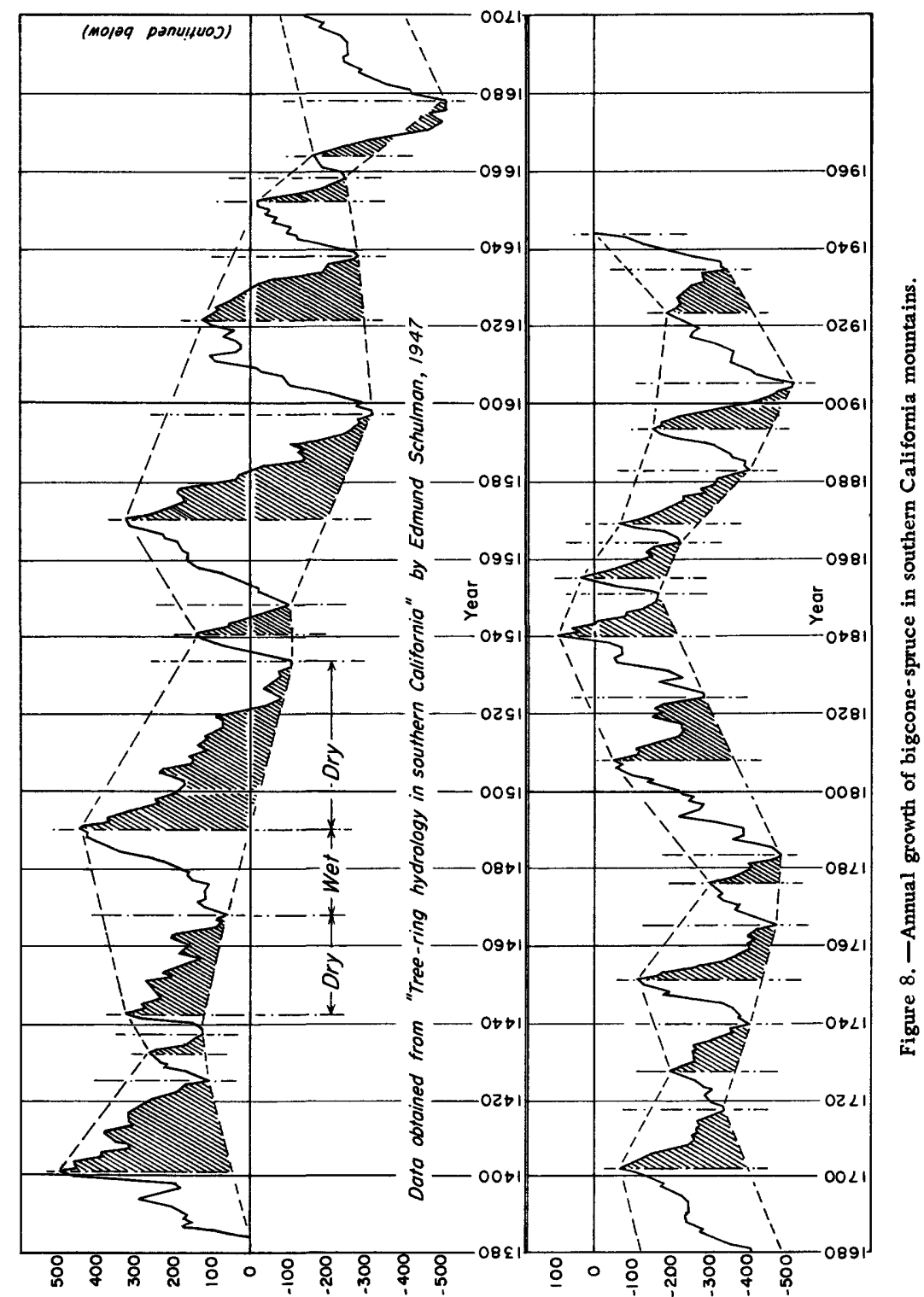

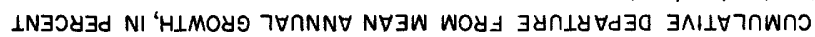


This record shows a continuous dry period extending from 1490 to 1533. During this 43-year period, the recharge to local water reserves was probably very meager. A dry period of this length has not been experienced by civilized man in California. Three other dry periods had lengths of more than 20 years. In contrast three dry periods were shorter than 10 years. The median, or normal, dry period is about 14 years.

\section{RECOVERABLE WATER}

The scrubby and dwarfed drought-resistant native vegetation of the mountains, and the more luxuriant vegetation in the cienaga areas or along the water courses of the valley floor, consume a major part of the precipitation falling in the area. Only in the higher and cooler parts of the coastal mountains does the annual precipitation consistently exceed the water requirements of the native vegetation.

In the high mountain drainage area of Deep Creek below Green Valley Creek, which has an average altitude of 6,600 feet, the annual water requirement of the native vegetation is 18.4 inches, or 49 percent of the basin-wide average annual precipitation of 37.5 inches. This leaves a residual of 19.1 inches of recoverahle water over the entire area, available for recharge of ground-water reserves and for surface runoff.

This average annual recoverable water of 19.1 inches includes the surface and subsurface outflow from the mountain drainage area, and any change in basin-wide ground-water storage that might have taken place between the beginning and ending of the period. The periods generally include 30 to 50 years of record, so that the average precipitation and outflow values can be considered as representative. The surface outflow can be observed and the change in basin-wide ground-water storage obtained by indirect methods on the basis of the observed runoff (Troxell and others, 1954). Generally the subsurface outflow at the gaging station must be estimated. Table 2 gives the precipitation, recoverable water, and the natural water loss (difference between precipitation and recoverable water) for a group of mountain drainage areas in which the subsurface outflow at the gaging station can be considered as zero.

In the equally high drainage area of Mill Creek, the average annual natural water loss amounts to 26.0 inches, or about 66 percent of the precipitation. As indicated in table 2, this natural water loss leaves a basin-wide residual of 13.4 inches of recoverable water available for recharge of the ground-water reserves and for surface runoff. 
Table 2.-Disposal of average annual precipitation in certain southern California mountain areas for the period 1896-1946 (Troxell and Stafford, 1949)

\begin{tabular}{|c|c|c|c|c|}
\hline Drainage area & $\begin{array}{l}\text { Average } \\
\text { altitude } \\
\text { (feet) }\end{array}$ & $\begin{array}{l}\text { Precipi- } \\
\text { tation } \\
\text { (inches) }\end{array}$ & $\begin{array}{c}\text { Natural } \\
\text { water } \\
\text { loss } \\
\text { (inches) }\end{array}$ & $\begin{array}{c}\text { Recover- } \\
\text { able } \\
\text { water } \\
\text { (inches) }\end{array}$ \\
\hline 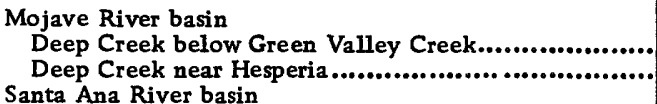 & $\begin{array}{l}6,600 \\
5,800\end{array}$ & $\begin{array}{l}37.5 \\
21.6\end{array}$ & $\begin{array}{l}18.4 \\
14.5\end{array}$ & $\begin{aligned} 19.1 \\
7.1\end{aligned}$ \\
\hline 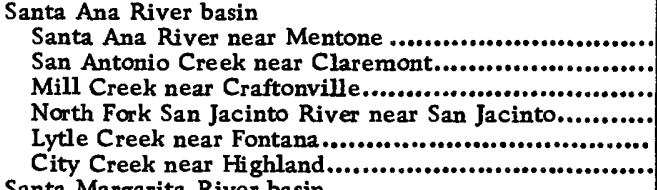 & $\begin{array}{l}7,000 \\
6,700 \\
6,600 \\
6,100 \\
5,400 \\
3,800\end{array}$ & $\begin{array}{l}29.3 \\
41.8 \\
39.4 \\
34.1 \\
39.3 \\
34.8\end{array}$ & $\begin{array}{l}22.8 \\
22.9 \\
26.0 \\
25.3 \\
27.5 \\
27.0\end{array}$ & $\begin{array}{r}6.5 \\
18.9 \\
13.4 \\
8.8 \\
11.8 \\
7.8\end{array}$ \\
\hline $\begin{array}{l}\text { Santa Margarita River basin } \\
\text { Temecula Creek at Nigger Canyon near Temecula .... } \\
\text { Whitewater River basin }\end{array}$ & 3,500 & 18.2 & 17.5 & .7 \\
\hline 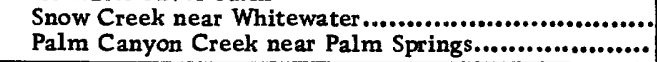 & $\begin{array}{l}6,200 \\
3,900\end{array}$ & $\begin{array}{l}33.3 \\
14.1\end{array}$ & $\begin{array}{l}21.1 \\
12.9\end{array}$ & $\begin{array}{r}12.2 \\
1.2\end{array}$ \\
\hline
\end{tabular}

As the altitude decreases, a larger proportion of the precipitation is consumed by native vegetation. In the lower mountain drainage area of Temecula Creek at Nigger Canyon near Temecula, 96 percent of the precipitation is required to satisfy the natural water losses. This leaves a basin-wide residual of only 0.7 inch of recoverable water available for use.

One can readily see that this recoverable water could be even smaller in the semiarid and arid interior valley floor areas. Unless imported water is available, man's successful occupancy of these regions depends upon his ability to use this recoverable water effectively, and to restrict his average annual water use so as to remain within the limits of this recoverable water which is the only local source capable of satisfying man's thirst and providing for his irrigation water.

\section{SURFACE WATER}

Surface water is an important component of the recoverable water available for downstream diversion, inflow to surface reservoirs and recharge to downstream ground water storage. Throughout much of southern California the periods of runoff and recharge are confined largely to the very intense flood flows occurring during or immediately following a rainstorm. During this period the hundreds of normally dry stream channels and arroyos contain large volumes of violently turbulent water. On such valley floor areas as the Yucaipa and Beaumont plains, about 88 percent of all the runoff occurs in 1 percent of the time. Thus, most of the surface runoff occurs in a period equivalent to about 3.6 days per year. 
In the more typical mountain drainage area of Cajon Creek, 50 percent of the runoff occurs in 2.9 percent of the time, or the equivalent of about 11 days per year. In the high and rugged mountain drainage of Lytle Creek, 50 percent of the runoff occurs in 16 percent of the time, or the equivalent of 58 days per year.

As these records show, a large part of the surface runaff occurs within very short periods of time. This concentrated nature of the runoff greatly complicates its salvage for the use of man.

As a result, surface runoff in many arid and semiarid areas becomes a very unstable source of water supply. Evidence of this extreme' instability is shown by the 63-year record of flow in Sweetwater River of San Diego County. During this period the annual runoff has ranged from 0 to 161,000 acre-feet; the mean annual runoff was 16,700 acre-feet, and the median annual runoff 6,220 acre-feet.

This instability is characteristic of all streams in southern California. For example (fig. 9), the annual runoff of the San Gabriel River since 1895 has ranged from 9,600 to 410,000 acre-feet; mean annual runoff was 114,000 acre-feet, and the median annual

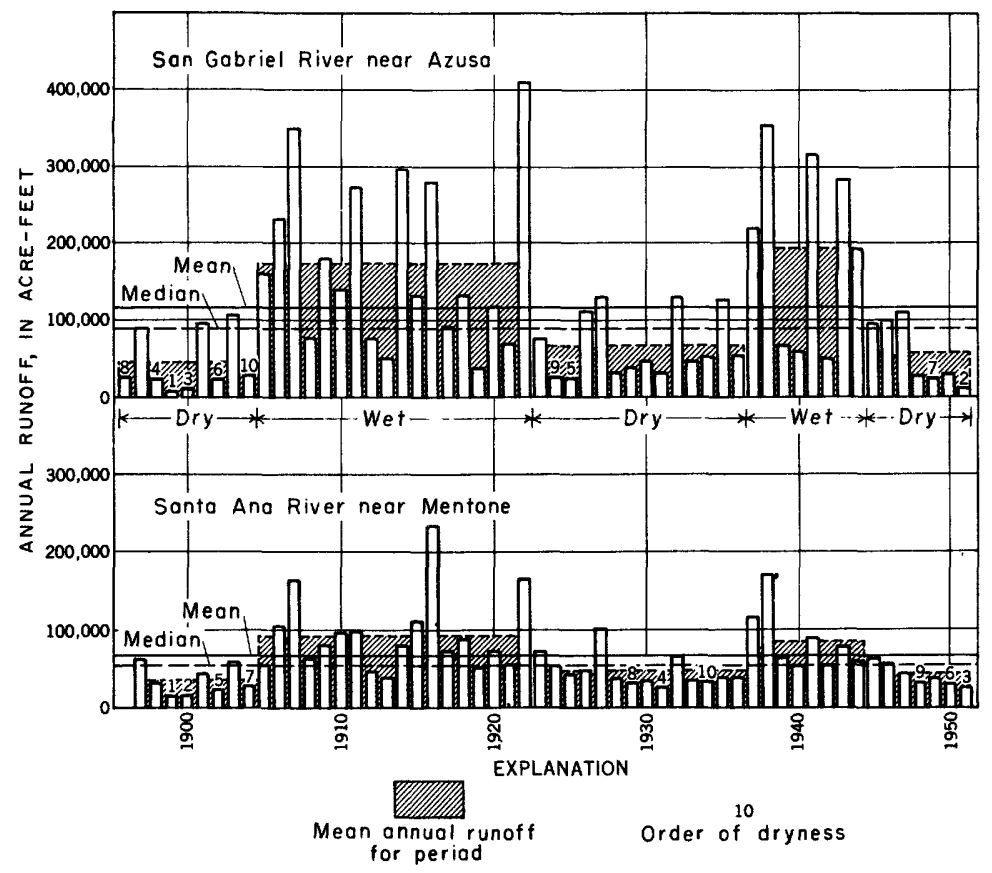

Figure 9. - Annual runoff of the San Gabriel and Santa Ana Rivers. 
runoff 87,800 acre-feet. The annual runoff of the Santa Ana River has been equally variable, for since 1896 it has ranged from 16,500 to 234,000 acre-feet, with a mean of 64,100 acre-feet and a median of 53,400 acre-feet.

By plotting the cumulative departures from the mean annual discharge, it has been possible to delimit the continuously recurring wet and dry periods. The mean annual runoff and certain characteristics of these wet and dry periods are given in table 3 .

Table 3.- Cyclic distribution of annual runoff

\begin{tabular}{|c|c|c|c|c|c|c|}
\hline \multirow[b]{2}{*}{ Date } & \multirow[b]{2}{*}{$\begin{array}{c}\text { Character } \\
\text { of } \\
\text { period }\end{array}$} & \multirow[b]{2}{*}{$\begin{array}{l}\text { Length } \\
\text { of } \\
\text { period } \\
\text { (years) }\end{array}$} & \multicolumn{2}{|c|}{ San Gabriel River } & \multicolumn{2}{|c|}{ Santa Ana River } \\
\hline & & & $\begin{array}{c}\text { Mean } \\
\text { of period } \\
\text { (acre-feet) }\end{array}$ & $\begin{array}{l}\text { Departure } \\
\text { from } \\
56-\text { year } \\
\text { mean } \\
\text { (percent) }\end{array}$ & $\begin{array}{c}\text { Mean } \\
\text { of period } \\
\text { (acre-feet) }\end{array}$ & $\begin{array}{l}\text { Departure } \\
\text { from } \\
55-\text { year } \\
\text { mean } \\
\text { (percent) }\end{array}$ \\
\hline $\begin{array}{l}1895-1904 \ldots \ldots \ldots \ldots \ldots \ldots \ldots \ldots \\
1904-22 \ldots \ldots \ldots \ldots \ldots \ldots \ldots \ldots \\
1922-36 \ldots \ldots \ldots \ldots \ldots \ldots \ldots \ldots \\
1936-44 \ldots \ldots \ldots \ldots \ldots \ldots \ldots \ldots \ldots \\
1944-51 . \ldots \ldots \ldots \ldots \ldots \ldots \ldots \ldots \ldots\end{array}$ & $\begin{array}{l}\text { Dry } \\
\text { Wet } \\
\text { Dry } \\
\text { Wet } \\
\text { Dry }\end{array}$ & $\begin{array}{r}9 \\
18 \\
14 \\
8 \\
7\end{array}$ & $\begin{array}{r}46,400 \\
172,600 \\
65,900 \\
192,500 \\
57,100\end{array}$ & $\begin{array}{l}-59 \\
+51 \\
-42 \\
+69 \\
-50\end{array}$ & $\begin{array}{l}36,200 \\
92,100 \\
45,800 \\
82,800 \\
38,800\end{array}$ & $\begin{array}{l}-44 \\
+44 \\
-29 \\
+29 \\
-39\end{array}$ \\
\hline
\end{tabular}

It will be noted that the range between the means for extended wet and dry periods is great. During the first 9-year dry period the mean runoff of the San Gabriel River was 46, 400 acre-feet, and in the following 18 -year wet period it increased to 172,600 acrefeet, an increase of 272 percent. The maximum usefulness of this runoff will depend upon the ability of the water users to store it during these extended periods of surplus for use in the equally extended periods of deficiency which follow. Because of local physiographic features, such as the steep and narrow mountain canyons, it is practically impossible to accomplish this goal by means of surface reservoirs.

On figure 9 it will be noted that the 10 driest years during the period of record are numbered. In the San Gabriel River drainage area, 6 of these years occurred in the first dry period, and each subsequent dry period had 2 of the 10 driest years. In the Santa Ana River drainage area, 4 of these driest years occurred in the first dry period and 3 in each subsequent dry period.

This distribution of the 10 most critical years, together with the runoff data in.table 3 , indicates the 9-year dry period of 18951904 to be the driest in the period of record. Its average runoff was 59 percent below the mean annual runoff in the San Gabriel 
River drainage area and 44 percent below the mean annual runoff in the Santa Ana River drainage area.

On this same basis the current dry period of 1944-51 appears to be the second driest of record. During this 7-year dry period, the mean annual runoff in the San Gabriel River drainage basin was 50 percent below the mean for the period of record, and in the Santa Ana River drainage basin it was 39 percent below the mean.

\section{GROUND WATER}

As a result of prolonged erosion, the weathered rock in the mountains of southern California has filled the many valleys with fairly pervious debris ranging in depth from a few feet to several thousand. This valley fill of poorly assorted debris is the primary source of the ground-water storage. Such storage is subject to recharge from stream runoff originating in the mountains and on the valley fill and to valley floor precipitation which penetrate below the root zone of the plant cover. This storage is depleted by outflow due to ground-water seepage in the lower reaches of the valley, natural water losses in the remaining areas of shallow water levels and more recently by the pumping extractions for domestic, industrial, and agricultural requirements of man.

By far the most important and largest part of the residual between the precipitation and the natural water loss is that stored in the ground-water reserves of the valley fill. Some indication of the magnitude of these reserves was demonstrated by Eckis (1934). He found that ground-water storage capacity in the valley floor areas of the Los Angeles region (the south coastal ground-water basin), excluding the San Jacinto River basin, contained about $6,900,000$ acre-feet in a zone 100 feet thick extending from 50 feet above to 50 feet below the ground-water level of January 1933. This storage capacity is equivalent to more than 12 times the entire combined capacity of all existing surface reservoirs built in the Los Angeles region for both flood control and conservation (Troxell, Poland, and others, 1951). This storage capacity is also equivalent to almost 14 times the combined mean annual runoff from all the mountain and foothill areas tributary to the valley floor of the Los Angeles region. Consequently these ground-water reserves are the principal source of water throughout much of southern California and their importance cannot be overemphasized.

These reserves are dependent upon the physiographic and geologic features of the areas as well as hydrologic conditions and are not uniform in all of southern California. The most favorable geologic zones for ground-water storage are the valley fill areas. 
The ground-water storage capacity of these alluvial valleys may range from a few acre-feet to many thousand acre-feet.

\section{RECENT DROUGHITS}

Since 1893 there have been three recognized droughts in southern California. While hydrologic factors governed the length and sequence of these dry periods, man's water requirements generally determined the severity of the effects of the drought. As man's water requirements increase, the adverse effect of the drought on his economy also increases. And frequently these economic features form the principal index of the drought's magnitude in the mind of the public.

In order to avoid confusion in this report, it has been necessary to fix a common beginning and ending for each of the three drought periods in southern California. These have been largelydetermined on the basis of hydrologic factors such as those listed in the following table:

Table 4.-Drought periods as indicated by three hydrologic factors

\begin{tabular}{|c|c|c|c|}
\hline $\begin{array}{c}\text { Runoff of } \\
\text { Santa Ana and } \\
\text { San Gabriel } \\
\text { Rivers }\end{array}$ & $\begin{array}{l}\text { Precipitation } \\
\text { at Los Angales } \\
\text { and Cuyamaca }\end{array}$ & $\begin{array}{l}\text { Annual tree } \\
\text { growth }\end{array}$ & $\begin{array}{l}\text { Period used } \\
\text { in this } \\
\text { report }\end{array}$ \\
\hline $\begin{array}{l}1895-1904 \\
1922-36 \\
1944-51\end{array}$ & $\begin{array}{l}1893-1904 \\
1917-34 \\
1944-51\end{array}$ & $\begin{array}{l}1893-1904 \\
1923-37 \\
. . \ldots \ldots . . . . . . . . .\end{array}$ & $\begin{array}{l}1893-1904 \\
1922-34 \\
1944-51^{4}\end{array}$ \\
\hline
\end{tabular}

Table 3.

2 Table 1.

${ }^{3}$ Figure 8 .

May not be completed.

\section{CULTURAL DEVELOPMENT}

\section{HISTORY OF SETTLEMENT AND GROWTH}

\section{SPANISH OCCUPATON}

To forestall an imminent threat of Russian occupation of Alta (Upper) California, the Spanish government at Madrid in 1768 instructed the Viceroy at Mexico City to dispatch several expeditions from Baja (Lower) California for the purpose of formally occupying the area. In July 1769, Gaspar de Portola established a settlement at San Diego and in the following months explored the coast as far 
north as San Francisco. On June 3 of the following year a presidio (garrison) and mission were established at Montery, marking the completion of the official occupation of Alta California, now known as the State of California.

These early settlers led a precarious existence for want of suitable food supplies. The presidio and mission at San Diego were largely provisioned by supply ships from Baja California. To provision the garrison at Monterey, food was sometimes transported overland from San Diego by pack animals. The failure of the supply ships or pack trains to arrive at their destination often resulted in considerable hardship.

\section{MISSION PERIOD}

The aborigines were largely of a nomadic nature, ceaselessly roaming from area to area in search of food and clothing. Consequently, there were no formal settlements or any extensive agricultural activities in southern California before the arrival of the missionaries in 1769 .

Because of the importance of establishing reliable food supplies, these early missionaries also acted as agriculturists. They made many notes referring to the rainfall, floods, or droughts occurring in the area (Lynch, 1931). Beginning about 1774, they maintained fairly complete records of the planting and harvesting of the three principal field crops: wheat, barley, and corn. From their earlier experience in Baja California, they were thoroughly familiar with the semiarid and arid climates of southern California. They fully understood the annual summer dry period of these regions and realized that customary crops would generally not mature unless the soil moisture during the growing season could be augmented by additional water. This additional water was generally obtained from cienagas or diversions from the perennial streams crossing the valley-floor areas. Such water sources were sustained by the effluent seepage from the ground-water reserves and were, to a degree, independent of the usual vagaries of the precipitation distribution.

The importance, and the permanency of these water sources were early recognized. This is emphasized in the following letter of instructions dated December 17, 1773, from the Spanish Viceroy in Mexico City to Father Junipero Serra:

Before the Mission [at San Diego] is removed to the new locality the [matter of first importance [to consider] is the cultivation of the land, acquisition of water, and facility in making fruitful the soil, which may be in the beginning of a temporary nature. This may be accomplished by small ditches from pools of water or wells in the bed of the stream of water or outside of the bed in wells [made] by labor in a better chosen place, that by this 
means [there may be] no loss touching the very necessary food supply, there being thus no scarcity during the removal. But at a subsequent time and in a more opportune manner the Father should cause to be constructed a firm dam from which [water] may be drawn for the future Pueblo, and agriculture and mills in this community, because great hopes are placed in [its being] a fine city some day. ${ }^{\text {? }}$

The actual construction of a masonry dam and connecting aqueduct were probably not accomplished till some 40 years later. On the basis of sound engineering judgment this dam was built in a narrow section of the river about 6 miles upstream from the mission in an area of continuous ground-water seepage.

In other areas, the task of obtaining supplemental sources of ten required the building of even longer aqueducts. Between 1820 and 1830 the Indians under the direction of the Mission fathers built the 11 -mile long Zanja (ditch) over difficult boulder-strewn terrain to bring water from the more mountainous sections of Mill Creek to the Asistencia of the San Gabriel Mission near Redlands.

\section{THE FIRST PUEBLO IN SOUTHERN CALIFORNIA}

As a means of supplying subsistence and other services for the presidios, the Spanish Viceroy on September 4, 1781, established the pueblo Nuestra Senora La Reina de Los Angeles (Our Lady the Queen of the Angels) on the banks of the Rio de Porciuncula. From its original population of 46 persons, this pueblo has developed into the modern city of Los Angeles. The Viceroy granted this pueblo the absolute and exclusive ownership of the waters in the Rio de Porciuncula or the present-day Los Angeles River.

\section{EARLY DROUGHTS}

In very few areas have the prolonged droughts and their continuous reoccurrence had greater influence on the cultural development than in southern California. Father Sanchez of the San Gabriel Mission, in a letter to Father Lasuen on April 26, 1796, stated that:

*** in the year preceding this, we saw ourselves compelled to send half of the neophytes for some months into the mountains to search for food after the manner of savages, whilst we maintained those staying here on half rations, and a little milk, until the time of the wheat harvest. (Lynch, 1931, p. 2)

The vagaries of the weather are such that they reflect flood conditions one year and drought the next. For example, Davis indicates that:

\footnotetext{
${ }^{1}$ Green, N. E., 1932, San Diego old mission dam and irrigation system (manscript).
} 
$* * *$ the winter of $1839-40$ was a severe one in California, an immense quantity of rain falling. It poured down for forty days and nights with but little cession-During the prolonged storms of this year the whole country was flooded. (Lynch, 1931, p. 4)

Then during the very next year Lynch (1931, p. 5) quoted Duflot de Mofres as writing that

In 1841, they had sown so little grain in Upper California, and the harvest was so poor because of the drought that they sent two schooners to San Blas and to Guaymas to look for meal-flour.

Also quoting Belden (Lynch, 1931, p. 5),

I think in the earlier years I was here from 1841 on for perhaps ten or twelve years the seasons were less favorable for cultivation than they have been since. There was more drought - I think the proportion of the dry seasons to the wet ones was greater from 1841 to ' 51 or ' 52 than it has been since.

\section{PASTORAL ERA}

Because of the semiarid nature of the climate and reoccurring droughts, the agricultural activities of the missions were supplemented by cattle raising, often on a fairly large scale. This was encouraged by an illicit trade which developed with the captains of foreign ships, who, exchanged manufactured goods for hides and tallow. Much of this trade was with the missions for they alone were equipped to provide these hides and tallow. This was the mere beginning of a highly profitable activity. After the mission period cattle raising became the principal industry of the area. This type of agriculture required the large land holdings so characteristic of the early Spanish and Mexican land grants.

The methods of cattle raising remained unchanged, with the range supplying all the feed throughout the year without the assistance of granary or haystack. These open ranges of southern California were believed to have supported about 180,000 head of cattle in 1854 (Cleland, 1939, p. 303-304).

The very severe drought of 1856-64 proved to be one of the most significant periods in southern California agriculture. Even though severe, this drought included the "great flood" or the "Noachian deluge of California floods" during the winter of 186162 (Troxell and others, 1942; also, McGlashan and Briggs, 1939). This drought was significant because it represented the beginning of the end of the thriving cattle-raising industry. Quoting from Cleland (1939, p. 308)

The loss of cattle was fearful-The plains were strewn with their carcasses. In marshy places and around the cienegas, where there was a vestige of green, the ground was covered with their skeletons. It is said that 30,000 head of cattle died on the Steam's Ranchos alone. The great drought of 1863-64 put an end to cattle raising as the distinctive industry of southern Califomia. 
Probably as a result of this drought more than any other influence, many of the large land holdings were divided into small ranches. This proved to be the beginning of the era of diversified and highly productive forms of agriculture as practiced today.

\section{MODERN AGRICULTURAL ERA}

The irrigation practices first established by the mission fathers remained fairly static during the cattle raising era. With the completion in 1877 of the transcontinental railways into Los Angeles, irrigation farming again became predominant. This revival resulted mainly from the large money returns from certain highly specialized crops.

The citrus tree was first introduced into southern California about 1854, and by 1860 many thousands of trees were under cultivation. However, the real impetus came in 1873 when the Brazilian navel orange was introduced. With satisfactory transportation to market available, these and other crops became valuable sources of income. The other crops included alfalfa, sugar beets, and beans ${ }^{\circ}$ and many other vegetables. The growing of deciduous fruit and walnut trees also became important. With the rapid growth in population, dairying became a major agricultural activity.

\section{THE GREAT BOOM}

In 1887 there developed a real estate boom, called by many the Great Boom. During this period, land was still relatively cheap and the agricultural possibilities of the area were becoming more widely known. The real foundation for this boom lay in the publicity campaigns of the local chambers of commerce and real estate companies. These campaigns were greatly facilitated by a transportation price war indulged in by the two transcontinental lines then serving southern California. Cleland (1939, p. 441) states:

At the time this rate cutting began tickets from Mississippi Valley points to Los Angeles cost about a hundred and twenty-five dollars. Within a few months this rate had been greatly reduced; and as the war went merrily on, the railroads carried people to California almost free of charge. A five dollar ride from Missouri to Los Angeles remained in force for three months; and at least for one day during the keenest period of competition, the fare was actually lowered to a dollar. 


\section{SEARCH FOR NEW SOURCES OF WATER}

With this vast migration and the opening of more and more land for intensive agricultural use, the cost as well as the difficulties of developing supplemental water supplies greatly increased. For these reasons the agriculturist, as an individual water developer, was soon destined to fade from the picture. In substitution, groups of agriculturists began forming water companies or mutual associations to improve and preserve their common sources of water. As a first step, these mutual groups generally made every effort possible to salvage existing wastes and develop new supplies. Canal systems were lined to reduce seepage losses and occasionally were replaced by underground pipelines to reduce evaporation losses. Submerged dams were built across otherwise dry stream beds to intercept the subsurface flow. Subsurface drainage galleries were dug in the recent alluvialdeposits at the mouths of the canyons to intercept the underflow. Also, some success was had by developing short tunnels into the mountain sides to obtain water.

\section{VALUES OF WATER RUGTS}

This steadily increasing demand for both land and supplemental water caused the value of water rights to sky-rocket during the late 1870 's and early 1880 's. William Ham. Hall, State Engineer (1888 p. 151 and 167 ) gives the following changes in the value of the water right to a continuous flow of 1 miner's inch, or 1/50 of a cubic foot persecond, in two canal systems near San Bernardino (see table 5). This large increase in the value of water rights was

Table 5. - Value of irrigation water rights near San Bernardino, Calif., 1865-88

\begin{tabular}{|c|c|c|}
\hline \multirow{2}{*}{ Date of water rights sale } & \multicolumn{2}{|c|}{$\begin{array}{c}\text { Value of the water right to } 1 \text { miner's inch } \\
\text { of continuous flow }\end{array}$} \\
\hline & North Fork Water Co. & South Fork Canal \\
\hline 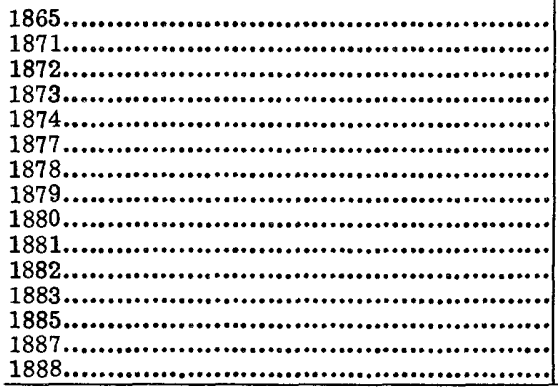 & 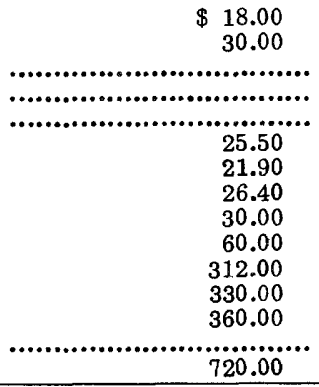 & 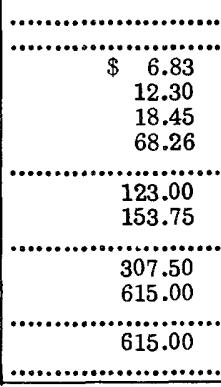 \\
\hline
\end{tabular}


due to the increasing demand for supplemental water and the anticipation of developing mountain storage at Bear Valley. Hall also indicates that in 1887 the San Diego River Flume Company sold the rights to 400 miner's inches, or 8 cubic feet per second, to the San Diego Land and Water Company for $\$ 320,000$. Some years later Tait (1912, p. 275) indicated that rights to water from gravity sources under company systems with well-established rights were worth from $\$ 100,000$ to $\$ 150,000$ per cubic foot per second. The value of similar rights are even greater today.

\section{THE USE OF GROUND WATER}

Before 1870 , some of the water users in southern California discovered that a pipe driven about 100 feet or more into the ground in moist or cienaga areas often produced a flowing well. Generally these were wells of small diameter and wereintended for domestic purposes. However, with the complete appropriation of most of the available surface water by 1880 , many of the water users started installing wells of larger diameter in the cienaga areas with the hopes of developing a flowing well capable of satisfying their irrigation requirements. As the great agricultural boom of 1880 to 1890 progressed, hundreds of flowing wells were developed in the Santa Ana, Los Angeles, and San Gabriel River drainage areas for obtaining supplemental irrigation water.

Because of the large withdrawals from these artesian water bodies, the water levels started to decline, with the result that some of the wells ceased flowing as early as 1890. By 1905, as shown by Mendenhall (1905a-d, 1908), the artesian areas were greatly reduced in size.

As the westward migration continued, the surface waters and the discharge from these flowing wells began to prove inadequate to satisfy completely all the water requirements. With the perfection of water-well drilling and pumping equipment, and the development of electric power and other cheap energy sources, efforts were made to exploit the large ground-water storage in the area. By 1905 Mendenhall reported (1905a, p. 10) that:

$* * *$ the Survey representatives have examined about 11,000 wells of all kinds, from those but a few feet in depth and used only for domestic supply or for stock, to bored wells 1,200 feet deep and yielding in many cases copious flows of ir rigation water.

\section{THE GREAT DROUGHT OF 1893-1904}

The severe drought in 1893-1904 was important because it represented a turning point in local water-development programs. 
The complacent water user suddenly discovered that the newlydeveloped ground-water resources were not inexhaustible as many had been led to believe.

The data already presented on figure 9 and in table 3 indicate this drought to be the most severe in the recorded history of the San Gabriel and Santa Ana Rivers. At the beginning of the drought the large irrigation and domestic companies soon discovered that the surface runoff would not satisfy their existing water requirements. They found it necessary to drill wells and install pumping equipments. During this drought the water level declined $28 \mathrm{feet}$ in the Neff well at Anaheim and 43 feet in the Williams well near Redlands.

Costly and involved litigation was instituted by neighbor against neighbor to curtail or prevent the placing of additional land in use. All seemed to agree that part of the trouble was due to deficient precipitation and part to overdevelopment, with no one being able or willing to delineate the extent of each.

\section{THE IMPERIAL VALLEY}

Through the joint efforts of Charles Rockwood, a pioneer engineer, and Anthony H. Heber and George Chaffey, early reclamationist, a project was organized to divert water from the Colorado River into the desert of Imperial Valley (Nadeau, 1950, p. 137146). By 1901 water was being delivered for use in the valley. However, in 1905, during a period of high flow, the Colorado River left its channel and broke into the Imperial Valley along the Old Alamo River channel. Within the next two years more than $16,000,000$ acre-feet passed through this break to form the present Salton Sea in the bed of ancient Lake Cahuilla. It was not until 1907 that the breach was finally closed, forcing the Colorado River to follow once more its usual channel into the Gulf of Lower California. This breakthrough made the economy of the valley precarious.

However, the greatly accelerated migration to it and productivity of its soil soon assured the valley a permanent and stable economy. With the completion of Hoover Dam and the formation of Lake Mead in 1936, future flood problems were solved and an adequate water supply assured. In 1942 the All-American Canal superseded the older Alamo Canal.

\section{LOS ANGELES AQUEDUCT}

The continuing migration of thousands of new residents to southern California taxed all existing water development facilities. 
During July 1905 the city of Los Angeles water authorities were forced to notify all water users of an impending critical water shortages, if the then-existing hot weather continued. The great drought of 1893 to 1904 convinced these water authorities that the local water resources were no longer sufficient to satisfy their existing and future requirements.

In 1905 the city of Los Angeles decided to go to distant Owens Valley, on the eastern side of the Sierra Nevada, to supplement its local water resources. This enterprise became a reality in 1907 when Los Angeles, then a city of about 160, 000 people, voted a $\$ 24,000,000$ bond issue to finance the project. This 215-mile aqueduct, completed in 1913, is now able to deliver a continuous flow of 480 cfs of Sierra Nevada mountain runoff to the city of Los Angeles (City of Los Angeles, 1916).

\section{THE BOOM OF 1920}

Before World War I most of southern California's phenomenal growth had been associated either with its climate or its agricultural productivity. Beginning about 1920 an industrial boom started which was destined to over-shadow all former booms. In the ten-year period of 1920 to 1930 , the population increased from $1,347,000$ to $2,933,000$.

One of the few great natural resources which seemed to be denied California was fuel. This lack of fuel proved to be quite a handicap in the development of transportation and the establishment of industrial enterprises. The handicap was suddenly and largely removed by the discovery of large petroleum reserves in southern California. Between 1920 and 1923 the annual petroleum production in Los Angeles, Ventura, Santa Barbara, and Orange Counties increased from $37,280,000$ to $211,800,000$ barrels, and the annual value of this output increased from $\$ 68,680,000$ to $\$ 201,500,000$ in the 3-year period (Symons, 1942). This increase in wealth may have been the trigger that started the industrial boom.

One of the best indices of this industrial growth is the consumtion of electrical energy in the metropolitan areas of Los Angeles and Orange Counties. The data in table 6 gives the total and per capita consumption since 1927. Within the city of Los Angeles, about 67 percent of this energy was used for commercial and industrial uses in 1927 and 42 percent in 1950. 
Table 6. - Annual consumption of electrical energy in the metropolitan areas of Los Angeles and Orange Counties

[From Los Angeles Chamber of Commerce (1951)]

\begin{tabular}{|c|c|c|}
\hline \multirow{2}{*}{ Year } & \multicolumn{2}{|c|}{$\begin{array}{l}\text { Consumption of electrical } \\
\text { energy in } 1,000 \mathrm{kwhr}\end{array}$} \\
\hline & Total & Per capita \\
\hline 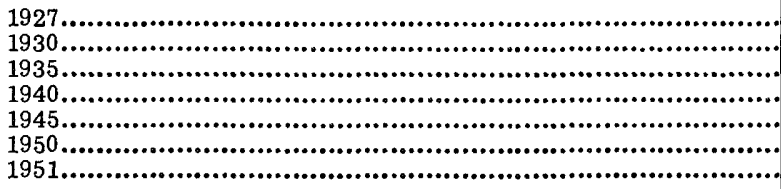 & $\begin{array}{r}2,066976 \\
2,779,992 \\
2,831,022 \\
3,879,170 \\
6,701,116 \\
9,233,419 \\
10,467,530\end{array}$ & $\begin{array}{l}1.01 \\
1.19 \\
1.07 \\
1.32 \\
1.86 \\
2.10 \\
2.28\end{array}$ \\
\hline
\end{tabular}

\section{COLORADO RIVER AQUEDUCT}

Doubling of the population, together with the industrial boom in 1920-30, once again overtaxed the water resources. By this time it was becoming evident that the local water resources, together with the current importations from Owens Valley, would not completely satisfy all of the water requirements.

The vast increase in industrial wealth and the mass prosperity during this decade created the ability to develop and to finance projects which would have been considered visionary 10 to 20 years earlier. Projects formerly considered economically unsound were now feasible because of increases in the demand for and value of water.

About 1924 sentiment began to crystallize for an aqueduct to the Colorado River that could serve most of metropolitan southern California. The citizens of the city of Los Angeles assumed the initiative by authorizing a $\$ 2,000,000$ bond is sue on June 2, 1925 for preliminary surveys. Then on December 6, 1928 "The Metropolitan Water District of Southern California" was incorporated for the purpose of developing and operating the aqueduct. In September 1931 the voters of this district authorized the issuance of a $\$ 220,000,000$ bond issue for the purpose of financing the 240-mile aqueduct (Metropolitan Water District of Southern California, 1939). The aqueduct, with an ultimate capacity of 1,500 cfs, was completed and placed in service in 1941.

The use of Colorado River water has not been mandatory on the member cities, but rather its availability is considered to be an insurance against future water shortages. As additional shortages developed, many communities in southern California sought entrance to the service area of the district. 
The growth of the area serviced by the district is shown on figure 10. The district's most phenomenal growth occurred at the very end of the current drought period, clearly suggesting

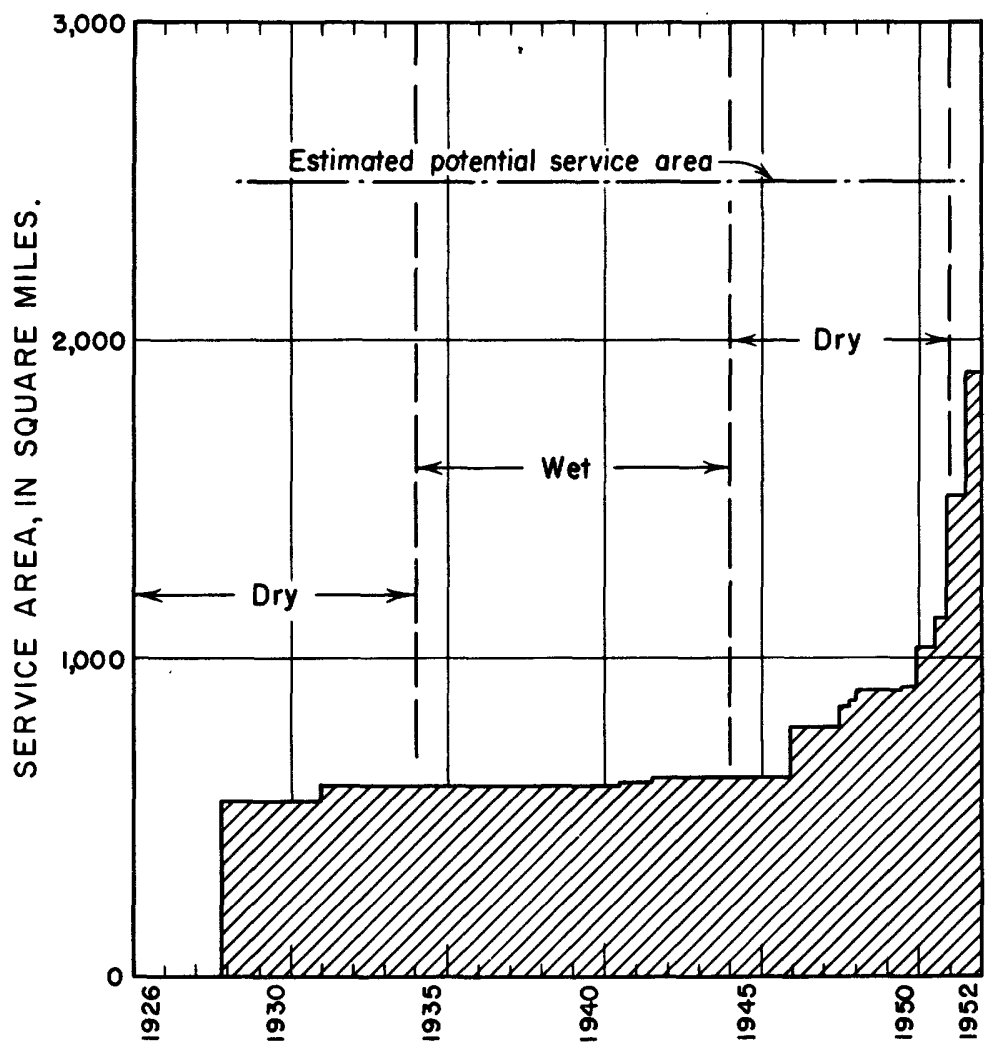

Figure 10. - Area serviced by Metropolitan Water District of southern California.

the depleted character of many of the local water reserves. In fact, by the end of 1952 about three-quarters of the 2,500-squaremile potential service area was within the district.

\section{MONO BASIN AQUEDUCT}

The continuous increase in water requirements made it desirable for the city of Los Angeles to enlarge the existing Owens Valley system to include the Mono basin immediately north of the Owens Valley. To obtain the waters from five streams in this basin, the present aqueduct system was extended northward for 
about 100 miles. This new section of the aqueduct, which included an 11-mile tunnel through the Mono Craters, was ready for use in April 1940. Adjuncts to this aqueduct are the 47,500-acrefoot Grant Lake reservoir completed in 1940 and the 183,700acre-foot Long Valley reservoir completed in 1941.

\section{WORLD WAR II}

Few areas have had the phenomenal increase in population experienced by southern California in the last decade. Largely as a result of World War II activities the population of this region has increased from $3,670,000$ in 1940 to $5,650,000$ in 1950. This represents a population increase of 65 percent.

An almost continuous migration into this area for many years had developed a large labor pool. Industry had long recognized the importance of this labor by establishing a large number of industries in the area. Many of these industries were closely associated with the prosecution of the war. The industrial expansion that resulted required considerable labor recruitment outside the area, and many of the newcomers decided to remain permanently in the area.

The extensive military establishments throughout southern California also introduced the area to people from other parts of the country. Many families moved to the area to be near the training centers and then remained while the men were overseas. Labor opportunities after the war made it possible for many returning veterans and their families to remain.

\section{SAN DIEGO AQUEDUCT}

The rapid expansion of the industrial and military establishments in the San Diego area following the declaration of war in 1941 resulted in a large increase in population. The county-wide population increased from 289,348 in 1940 to 556,808 in 1950 . It was soon apparent that the local water resources were insufficient to satisfy the need of this expanded population.

In 1944 a special committee appointed by the President of the United States recommended a 71-mile aqueduct from the Metropolitan Water District's west portal of the San Jacinto Tunnel to the city of San Diego's San Vicente Reservoir. The first contracts on this aqueduct were let on April 4, 1945, and the first water was delivered to San Diego in December 1947. The aqueduct has a designed capacity of 85 cfs and cost about $\$ 17,100,000$. The cost 
of this structure is to be repaid to the.Federal government over a 30-year period by the San Diego County Water Authority.

\section{SANTA BARBARA WATER SUPPLY}

Like most of southern California, this coastal community has nearly always experienced trouble satisfying the water requirements of those wishing to live in the area. As a result of extreme water shortages occurring in 1889, a far-sighted water company, after failing to find sufficient water in the short coastal streams adjacent to Santa Barbara, crossed the divide of the Santa Ynez Mountains and purchased several reservoir sites in the very much larger Santa Ynez River basin.

As a result of rigid water rationing during the dry years of 1898,1899 , and 1900 , the citizens in 1904 authorized a $\$ 600,000$ bond issue for the construction of Mission Tunnel through the Santa Ynez Mountains for the purpose of obtaining water from the Santa Ynez River (Citizen's Committee for Cachuma Water, 1949). Then between 1913 and 1919 the 13,000 to 19,000 inhabitants authorized bond issues totaling $\$ 820,000$ for the building of Gibraltar Dam and connecting its reservoir with Mission Tunnel. This reservoir made possible the retention of the Santa Ynez River flood runoff for use in periods of deficiency. The flood runoff thus detained was supplemented by a second reservoir built in 1930 by the adjacent community of Montecito. Because of the large debris load carried by the tributary mountain streams, the capacity of Gibraltar Reservoir had been reduced to half 'of its original capacity of 1948. In 1946 and 1948 the citizens of Santa Barbara were again called upon to vote a $\$ 1,100,000$ bond issue for enlarging Gibraltar Dam; this was completed in 1949.

As another drought period occurred, it became evident that these existing storage facilities were entirely inadequate for future needs. For that reason the Bureau of Reclamation was requested in 1941 to made a complete investigation of the region's water supply. By 1948 Congress had authorized the construction of the 210,000-acre-foot Cachuma Reservoir for further impounding the flood runoff of the Santa Ynez River. Also authorized was the construction of the 6.4-mile Tecolote Tunnel through the Santa Ynez Mountains for the purpose of conveying this water to the coastal communities near and including Santa Barbara. These facilities are now rapidly approaching completion. 


\section{TREND IN POPULATION}

Domestic water requirements are directly related to the population. For that reason the population, and its trend, are of prime importance to those responsible for developing the water supply.

After the coming of the early missionaries, the native Indians were gradually dispossessed by the more aggressive newcomers from the south. Included among these newcomers were the soldiers who established the presidios and the settlers who developed the pueblos and the vast ranchos. It has been estimated that the number of these immigrants in California increased from about 600 in 1780 to 3,270 in 1820 (Chapman, 1939, p. 385).

With the signing of the Treaty of Guadalupe Hidalgo on February 2, 1848. California was ceded to the United States by Mexico. The first official census of southern California in 1850 showed a population of 5,513 . The populations of the eight counties in the area are given in table 7 for the entire 100-year period of 1850 to 1950 . During this 100 -year period the population of the southern California counties showed a phenomenal increase from 5,513 to $5,652,249$. In 100 years the vast and sparsely settled grazing area of the early rancho has given way to the urban subdivision of today. Los Angeles County, once known as a "cow county," now has a population density of over 1,000 persons per square mile.

Early southern California was divided into three counties, those of Los Angeles, Santa Barbara, and San Diego. As the population increased, it was found necessary in the interests of more effective government to create San Bernardino, Ventura, Orange, Riverside, and Imperial Counties by subdivision within the original three.

As shown in table 7, the increase in population tends to follow a rather irregular pattern. The most significant gains in population occurred in 1880 to 1890 (The Great Boom), in 1920 to 1930 (The Industrial Boom), and in 1940 to 1950 (World War II). By way of emphasis, the rate of increase in population for each decade is given in terms of persons per day.

\section{AREA IRRIGATED}

Currently, the biggest use of water in southern California is for agriculture. During the major part of the first 100 years of agriculture in southern California the irrigated acreage probably increased rather slowly. The real awakening of agricultural possibilities through irrigation came about 1860. Before the Great 


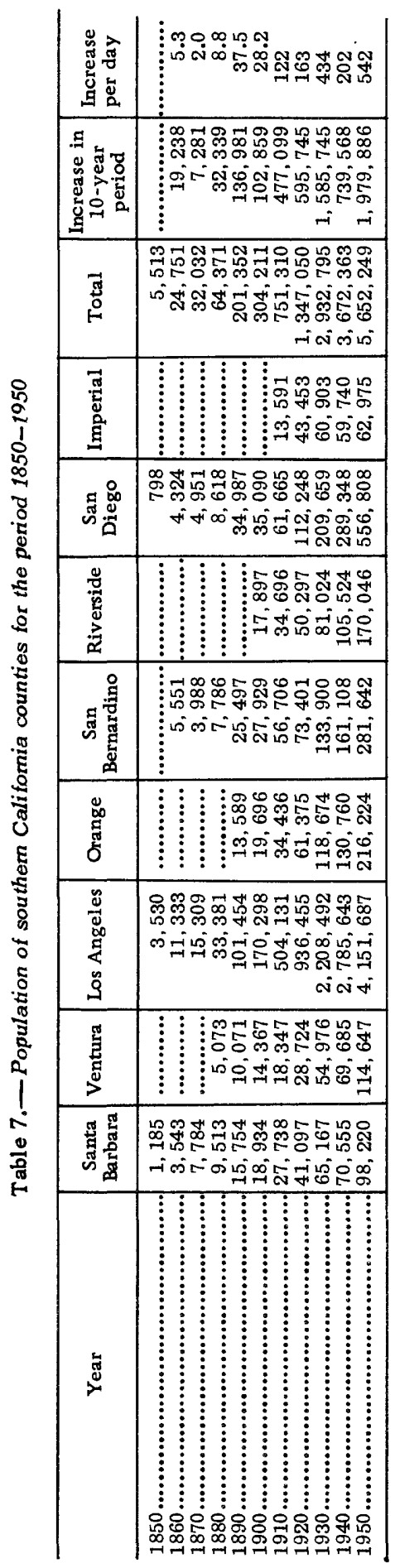


Boom in 1887 , there appears to be no reliable inventory of area irrigated.

In 1888 William Ham. Hall prepared a series of detailed maps showing the land under irrigation in the Santa Ana, San Gabriel, and Los Angeles River drainage areas. These are believed to be the first maps of this type produced in California.

The first State-wide inventory of the agricultural areas irrigated was made in 1900 as part of the regular Federal census program. From this and subsequent census inventories, it has been possible to prepare table 8, which gives the area irrigated in each of the eight southern California counties. Total irrigated acreage has increased from about 230,000 acres in 1900 to about $1,250,000$ acres in 1950 . However, almost 82 percent of this gain took place from 1900 to 1920 . During this 20-year period the area irrigated approximately doubled in each decade.

Table 8. - Irrigated areas of southern California, in acres, for the period 1900-19501

\begin{tabular}{|c|c|c|c|c|c|c|}
\hline County & 1900 & 1910 & 1920 & 1930 & 1940 & 1950 \\
\hline 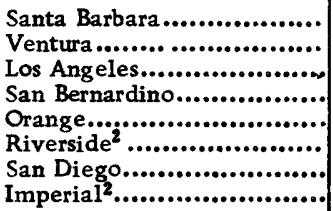 & $\begin{array}{r}3,218 \\
11,935 \\
85,644 \\
37,877 \\
41,549 \\
32,947 \\
16,022 \\
\ldots \ldots\end{array}$ & $\begin{array}{r}12,012 \\
25,273 \\
145,586 \\
70,278 \\
55,056 \\
71,436 \\
24,944 \\
190,711\end{array}$ & $\begin{array}{r}16,335 \\
31,716 \\
248,412 \\
105,306 \\
87,330 \\
106,212 \\
24,966 \\
415,304\end{array}$ & $\begin{array}{r}36,418 \\
88,519 \\
205,837 \\
108,482 \\
112,025 \\
135,617 \\
42,510 \\
432,240\end{array}$ & $\begin{array}{r}42,200 \\
86,134 \\
185,380 \\
111,041 \\
119,274 \\
122,040 \\
51,664 \\
422,834\end{array}$ & $\begin{array}{r}58,471 \\
107,699 \\
183,824 \\
106,970 \\
125,444 \\
159,364 \\
56,117 \\
451,847\end{array}$ \\
\hline Total.......................... & 229,192 & 595,296 & $1,035,581$ & $1,161,648$ & $1,140,567$ & $1,249,736$ \\
\hline
\end{tabular}

${ }^{1}$ From Ù. S. Census.

${ }^{2}$ Includes the Palo Verde and Yuma projects in California.

As indicated in table 8, Imperial, the youngest and least populous of all the counties, has the largest acreage of irrigated land. This county includes the very arid but famous Imperial Valley, which currently has more than 417,000 acres under irrigation. In 1951, it was necessary for the Imperial Irrigation District to supply the valley water users with 1,878,000 acre-feet of Colorado River water in order to mature the crops. This water was equivalent to 54 inches over the entire valley, or almost 18 times the annual precipitation of 3.04 inches $^{2}$ observed that year.

Los Angeles, while the most populous county, has the second greatest acreage of irrigated land in southern California. The irrigated acreage in this county reached a pleak about 1920 , after which it declined as a result of urban and suburban encroachment.

\footnotetext{
${ }^{2}$ Based on the record at Niland, Brawley, Imperial, El Centro, and Calexico.
} 


\section{WATER REQUIREMENTS}

The total annual water requirements of a region are the sum of the agricultural, domestic, and industrial water requirements. The agricultural requirement,as used in this report, is the quantity of water of satisfactory quality that must be used in addition to local precipitation to produce a crop.

In this report, the domestic and industrial water requirements are considered to be the quantity of water used for domestic and industrial purposes less the waste returned to fresh-water stream channels and ground-water bodies. The difficulty of separating the domestic and industrial requirements has made it necessary to consider the combined amount as represented by the water deliveries of the major service units. These deliveries have been considered to be equal to the water requirements in the coastal area, because the sewage is generally wasted to the ocean. In the interior valleys the water requirements have been estimated from the deliveries after adjustment for the amount of sewage recharge in the area.

\section{DOMESTIC AND INDUSTRIAL}

Because of the wide variation in climatic factors, together with the large number of service areas concerned, the past and present domestic and industrial requirements for southern California cannot be estimated reliably. However, on the basis of the 1951 annual report of the Metropolitan Water District of Southern California, about 600,000 acre-feet was consumed annually by about $3,600,000$ people, giving a unit use of 0.17 acre-foot per year, or 152 gpd per person.

Because this metropolitan area includes about two-thirds of the population of southern California, this unit rate is assumed to represent the present domestic and industrial water requirements for the entire population. Present water requirements per capita are probably substantially greater than those of 50 or 100 years ago. However, since no data are available about this change, the above unit rate has been used to estimate past and present water requirements given in table 9 which shows that the annual domestic and industrial water requirements have increased from a total of about 940 acre-feet in 1850 to 960,000 acre-feet in 1950 . 
Table 9. - Estimated annual water requirements, in acre-feet, for domestic and industrial purposes in southern California

\begin{tabular}{|c|c|c|c|}
\hline Year & $\begin{array}{c}\text { Water } \\
\text { requirements }\end{array}$ & Year & $\begin{array}{c}\text { Water } \\
\text { requirements }\end{array}$ \\
\hline 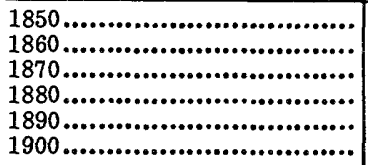 & $\begin{array}{r}940 \\
4,200 \\
5,400 \\
11,000 \\
34,000 \\
52,000\end{array}$ & 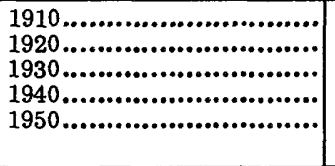 & $\begin{array}{l}130,000 \\
230,000 \\
500,000 \\
620,000 \\
960,000\end{array}$ \\
\hline
\end{tabular}

\section{AGRICULTURAL}

Before the colonization era, the predominant type of native vegetation in the valley floor areas was a group of dwarfed, droughtresistant, deep-rooted plants known locally as chaparral. In contrast, the less hardy modern agricultural crops have a shallower root system and completely different growing habits. Any soil moisture deficiency which might develop in the root zone of these crops might permanently affect the plant. Consequently, if agriculture is to be successful, the precipitation must be supplemented by irrigation water obtained from the area's water reserves.

The monthly water requirements for three typical southern California crops are shown on figure 11. These crops and locations have been selected to emphasize the effect of climatic

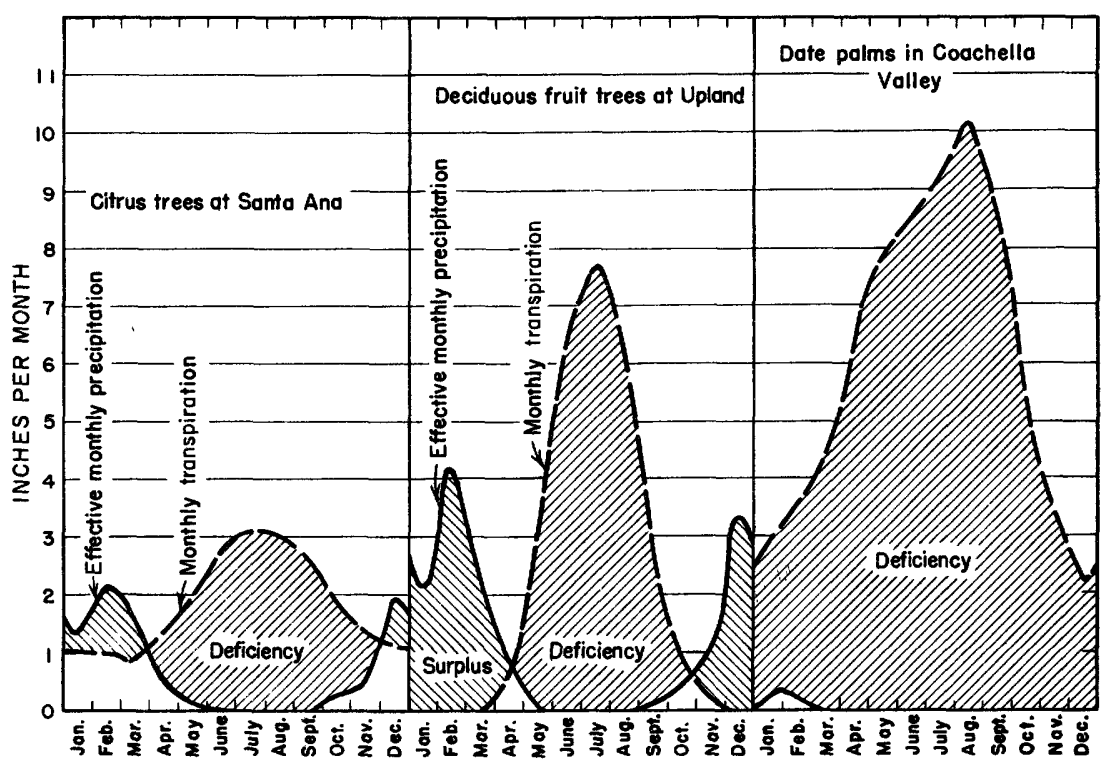

Figure 11. - Relation between monthly precipitation and transpiration. 
conditions on water requirements. As shown on figure 7 , potential evapotranspiration tends to increase with increasing temperatures associated with increasing distance from the ocean. Each crop cited used much more water in the hot and dry summer than in the winter. In the mild coastal area of Santa Ana, the average monthly transpiration of citrus trees ranged from 0.8 inch in the spring to 3.1 inches in July (Young, 1945, p. 40), while in the drier desert region of Coachella Valley, the date palms used from 2. 4 inches in December to 10 inches in August (Pillsbury, 1941 , p. 22).

Not all the precipitation that falls in an area is available for recharge of the moisture in the root zone of the plant cover. In some arid and semiarid regions a substantial part of the precipitation is lost by interception (the evaporation from leaves of the plant cover during and immediately following a rainstorm) and by evaporation from the soil. Effective precipitation as used in this report is that part of the precipitation that is not lost by interception and evaporation from the soil or by storm runoff. The mean annual effective precipitation at Santa Ana is believed to be about 8.1 inches out of an annual precipitation of 14.4 inches. Its distribution in inches per month is shown on figure 11.

Young (1945, p. 40) indicates that the annual transpiration of mature citrus trees in the Santa Ana area amounts to about 21.6 inches, with a monthly distribution such as shown on figure 11 . The effective precipitation of 8.1 inches will only partly satisfy this water requirement; the rest, 13.5 inches, must be obtained from the available water reserves. This additional moisture is the difference in crosshatched areas on the diagram showing the "surplus" and "deficiency."

At Upland the average annual effective precipitation is about 14.0 inches out of an annual precipitation of 22.2 inches. Young (1945, p. 43) indicates that the annual transpiration of peach trees near Upland amounts to about 27.5 inches. As a result, 13.5 inches of water must be withdrawn annually from the water reserves to mature the crop.

In Coachella Valley the average annual effective precipitation amounts to about 0.6 inch from an annual precipitation of 3.4 inches. According to Pillsbury (1941, p. 22), the date palms of this valley have an annual transpiration of about 72.4 inches. This means that 71.8 inches of irrigation water must be available annually to augument the local precipitation.

Each of these typical agricultural crops requires considerably more moisture than is provided by the local precipitation. Locally, the availability of the additional water is dependent upon the size 
of the water reserves. In areas of small reserves, it sometimes becomes necessary to curtail agricultural irrigation use because of depleted storage.

In the 50-year period of 1900-50, these annual agricultural irrigation requirements for crops have been estimated as increasing from 300,000 acre-feet to $2,900,000$ acre-feet. These values, obtained from table 10 , are based on the census crop records, the water requirements of the individual crops, and climatic factors. The greatest increase took place between 1900 and 1920 .

Table 10. - Estimated annual agricultural requirement used in southern California for agricultural purpases ${ }^{3}$

\begin{tabular}{|c|c|c|c|}
\hline Year & Acre-feet & Year & Acre-feet \\
\hline 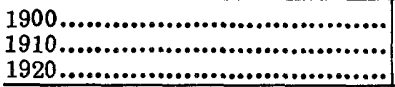 & $\begin{array}{r}300,000 \\
1,300,000 \\
2,500,000\end{array}$ & 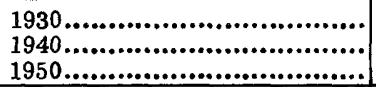 & $\begin{array}{l}2,800,000 \\
2,700,000 \\
2,900,000\end{array}$ \\
\hline
\end{tabular}

\footnotetext{
1 The following annual unit rates of agricultural requirement were used in preparing this table:
}

Los Angeles.

Orange.

Ventura

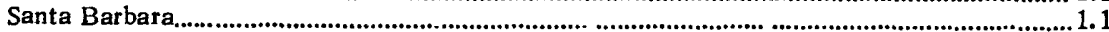

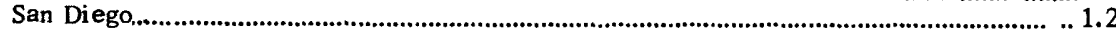

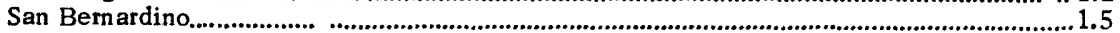

Riverside (includes Coachella and Palo Verde Valley)..................................................... 2.6

Imperial.

\section{WATER RESERVES}

In southern California these domestic, industrial, and agricultural requirements are obtained from local surface and groundwater reserves and from outside the area. In addition, there is at present the opportunity to salvage some of the water now being wasted into the ocean.

\section{SURFACE WATER}

The earliest source of water in valley floor areas was surface runoff. In the lower parts of the valleys, high ground-water levels created moist areas covered with dense water-loving vegetation. The early pioneer generally found these permanently moist or 
semimoist areas to be the choicest part of a valley. When cleared, these areas.would often support pasture grasses, deep-rooted fruit trees, and vines without the use of supplemental waters. However, some of the shallow-rooted crops, such as garden vegetables, needed some irrigation water during the hot summers to insure maturity. During each summer dry period, groups of settlers would place temporary brush dams in a stream channel nearby and divert the ground-water seepage through ditches to the area of use.

As the size of the settlements increased, it became necessary for the latecomers to locate outside of the permanently semimoist cienaga areas. These latecomers often had to go great distances, even as far as the mountain area, before permanent summer runoff could be found in the stream channels. It soon became apparent that there was a definite limit to the available water of this type. New water could only be had by developing storage in the mountain areas to retain flood water which would otherwise be wasted to the ocean. In September 1883 a group of agriculturists in the San Bernardino Valley organized the Bear Valley Land and Water Company to build the historic Bear Valley Dam and storage reservoir (Big Bear Lake) in the headwater area of the Santa Ana River in the San Bernardino Mountains. Then a few years later, in 1887, the Cuyamaca Reservoir of the San Diego River Flume Company was built in the Cuyamaca Mountains and the Sweetwater Reservoir of the San Diego Land and Town Company was completed in the foothill area of the Rancho Jamacho to conserve the flood runoff of the winter rainy season. To these reservoirs were added Lake Hemet in the San Jacinto Mountains during 1893 and Morena Reservoir in the Cuyamaca Mountains during 1895.

The success of these early reservoirs has resulted in the development of many additional reservoirs having capacities ranging from a few acre-feet to more than 200,000 acre-feet. However, because of adverse topographic conditions, most of these reservoirs have very limited capacities. Their capacities, classified by use and date of construction, are shown in table 11.

With an ever-growing population, it became increasingly difficult for many urban communities to obtain sufficient water to satisfy their needs. Consequently, as the size and wealth of these communities increased, they, too, planned and built reservoirs to store the winter flood runoff which would have otherwise wasted to the ocean.

The recent rapid urbanization of much of the valley floor area has made it necessary to develop a series of flood-control reservoirs to protect the life and property of those encroaching on the natural flood channels. In the fulfillment of this purpose, large 
Table 11.-Storage capacity and purpose of reservoirs constructed between 1880 and $1950^{2}$

\begin{tabular}{|c|c|c|c|c|}
\hline \multirow[b]{2}{*}{ Period in which completed } & \multicolumn{3}{|c|}{ Purpose of reservoir } & \multirow{2}{*}{$\begin{array}{l}\text { Capacity } \\
\text { (acre-feet) }\end{array}$} \\
\hline & $\begin{array}{c}\text { Irrigation } \\
\text { (acre-feet) }\end{array}$ & $\begin{array}{l}\text { Municipal } \\
\text { (acre-feet) }\end{array}$ & $\begin{array}{c}\text { Flood } \\
\text { control } \\
\text { (acre-feet) }\end{array}$ & \\
\hline 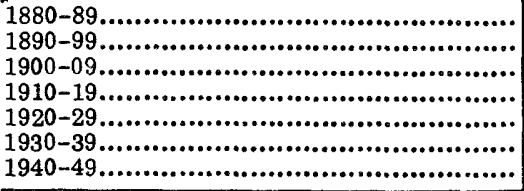 & $\begin{array}{r}64,400 \\
74,500 \\
2,100 \\
54,600 \\
234,000 \\
27,900 \\
92,300\end{array}$ & $\begin{array}{r}107 \\
5,600 \\
122,300 \\
124,300 \\
301,600 \\
117,300\end{array}$ & r & $\begin{array}{r}64,400 \\
74,600 \\
7,700 \\
176,900 \\
386,800 \\
389,200 \\
524,400 \\
\end{array}$ \\
\hline 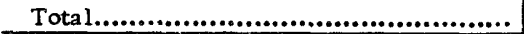 & 549,800 & 671,200 & 403,000 & $1,624,000$ \\
\hline
\end{tabular}

\footnotetext{
${ }^{1}$ From "Dams within jurisdiction of State of California," California Division of Water Re-
} sources, February 1950.

parts of the flood runoff are temporarily stored in these reservoirs, to be subsequently released in smaller quantities to recharge the valley ground-water reserves.

\section{GROUND WATER}

Southern California's largest water reserves are stored underground in the many alluvial valleys that extend along the coast. The amount of this storage is governed largely by geologic, physiographic, and meteorologic conditions. Consequently, the areal distribution is quite irregular.

Because of their fairly wide distribution these ground-water reserves have been the principal water source for much of the area. The census indicates that the 4,200 pumped wells used for irrigation in 1910 increased by more than 120 percent to 9,400 pumped wells in 1940. The effect of this added pumping has been to reduce the number of flowing wells used for irrigation purposes from 1,600 in 1910 to 250 in 1940 .

As already indicated, in the pioneer days most householders attempted to provide for their own domestic water requirements by drilling a well near the house. This method of supply soon proved inadequate with the development of the era of urbanization and subdivision. To satisfy the water requirements for these areas, service units were organized for the purpose of providing and distributing waters. In its 1940 inventory the California Department of Public Health listed more than 150 service units supplying domestic water to the people of southern California. More than 90 percent of these service units are completely or partly dependent upon ground-water resources for their supply. 
The overall effectiveness of these reserves is dependent upon their recharge either by natural or artificial means. The artificial recharging of these reserves by water spreading has been practiced on a fairly wide scale for many years.

\section{IMPORTED WATER}

In recent years annual water requirements of southern California have greatly exceeded the annual replenishment of the local reserves. Consequently it has been necessary to import water from outside the area wherever that has proven possible. As a result, there now exist diversions from Owens and Mono basins on the eastern side of the Sierra Nevada and from the Colorado River at Parker and Imperial Dams. These annual importations are shown on figure 12 .

The importation of water from the Colorado River has proven to be the only available source of water for the arid Imperial Valley and a partial source for the equally arid Coachella Valley. This diversion from the Colorado River was established in 1901 by the building of the Alamo Canal which supplied water to both sides of the internationalborder. In 1942 the All-American Canal, located entirely within the United States, was placed in operation for the purpose of providing water for the Imperial and Coachella Valleys.

The bottom graph on figure 12 gives the annual diversion from the lower Colorado River, based on streamflow data furnished by the Imperial Irrigation District. The first part of this graph shows the diversions of the Alamo Canal for the water years of 1909 to 1940 , and represents the combined deliveries to both sides of the border. The second part of this record shows the estimated or observed part of this diversion used on the north side of the border. It is evident from these data that this Colorado River diversion forms the principal importation into southern California, and has averaged more than $2,600,000$ acre-feet annually during the period 1935-51.

The diagram in the midpart of figure 12 gives the second largest importation into southern California, which is that of the city of Los Angeles from the Owens and Mono basins. This diversion, starting in 1913, has steadily increased; 325,000 acre-feet was delivered in 1951 .

The top part of figure 12 gives the most recent source of imported waters, the Metropolitan Water District of Southern California Aqueduct from the Colorado River. Since 1941 the annual 


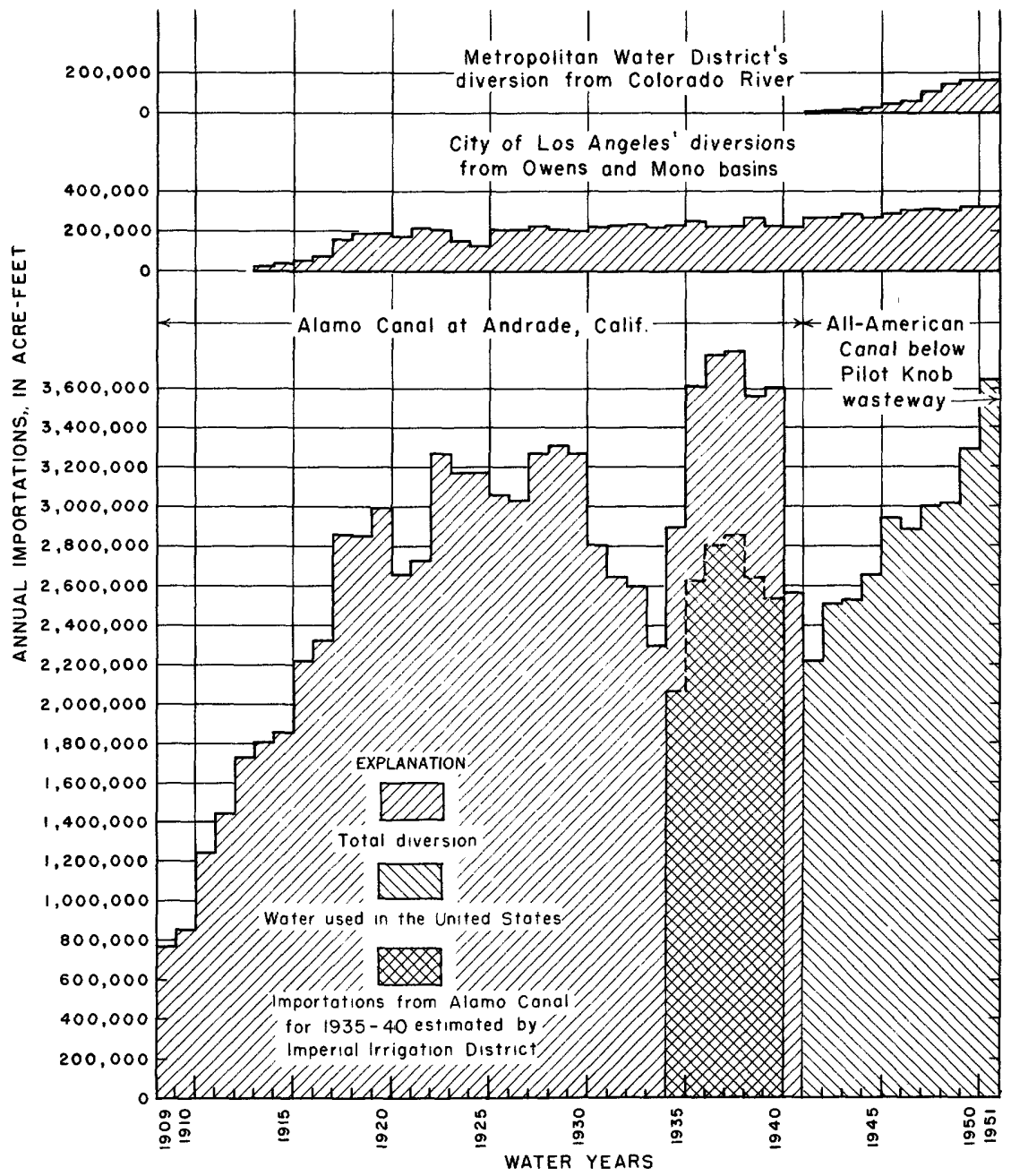

Figure 12.-Annual water importations to southern California.

importations from this aqueduct have rapidly increased to about 166,000 acre-feet in 1951.

\section{WASTE}

Flow to the ocean. - The State Water Resources Board (1951) has es timated that the precipitation in the coastal drainage areas of southern California produces an average annual natural runoff of about 1,600,000 acre-feet. But because of unfavorable topography, 
together with the lack of suitable surface- and ground-water storage, about 47 percent of this runoff, or 750,000 acre-feet, wastes annually into the ocean; although during the drought of 1944-51 the mean annual wastage to the ocean was reduced to 150,000 acre-feet.

Uneconomic evapotranspiration.-Since the first clearing of the cienaga areas, the large evapotranspiration losses due to phreatophytes (water-loving plants) have gradually been declining. At present, competition for water has become so great that most of this type of cover has been eliminated.

Muckel and Blaney (1945) estimated that the water-loving vegetation of the San Luis Rey Valley consumed about 18,000 acre-feet annually. Troxell (1933) has estimated that this same type of vegetation along the Santa Ana River consumed about 17, 000 acrefeet. Reliable areal estimates of the total losses due to this source throughout southern California are not available.

In the desert regions, a considerable part of the mountain runoff is often wasted into the many inland desert lakes and playas where it is eventually disposed of by evapotranspiration.

Sewage.-Because of increasing population, the primitive sewage disposal of the early pioneer has evolved into a complicated array of modern sewage disposal plants and ocean outfall sewers. Formerly, through the use of septic tanks and cesspools, the household returned nuch of its sewage to ground-water storage. Then, through community-wide effort, common sewers were developed, which commonly drained directly into sewage farms.

As early as 1883, the city of Los Angeles entered into a contract with the South Side Irrigation Company for the disposal of the discharge of the San Pedro Street sewer. In 1895 and 1896 about 1, 550 acres between Inglewood and Gardena were irrigated from the new outfall sewer to the Pacific Ocean (Rafter, 1899, p. 83). During the height of the irrigation season this water sold for the premium price of $\$ 2$ per acre-foot. Mendenhall (1905c, p. 19) indicated that this acreage had increased to about 3,600 acres in 1904.

In 1893 an 800-acre sewage farm was established by Pasadena in what is now the southeastern part of Alhambra. A complete sewage disposal plant at the same location was continued in operation until a few years ago.

These space-consuming and of ten odoriferous farms have completely given way to the more efficient and modern sewage treatment plant, where the effluent is frequently returned to the normal 
stream channels for reuse as irrigation water or for recharge to ground-water storage.

As property values and the need for new lands increased, there has been a trend toward outfall sewer systems discharging into the ocean. Of the 200 or so municipalities or other political subdivisions in southern California, 91 now discharge their sewage into the ocean (U. S. Public Health Service, 1951). During 1950 these combined sewer systems are believed to have wasted about 500,000 acre-feet to the ocean.

The combined annual discharge of the four principal outfall sewer systems of metropolitan Los Angeles is shown on figure 13 for the water years of 1928 to 1950 . These outfall sewer systems include the Hyperion and Terminal Island systems of the city of Los Angeles, the Los Angeles County Sanitation District, and the Orange County Joint Outfall Sewer. By enlargement of their service areas and the increase in population, the annual discharge has increased by 203 percent during the 23-year period of 1928-50.

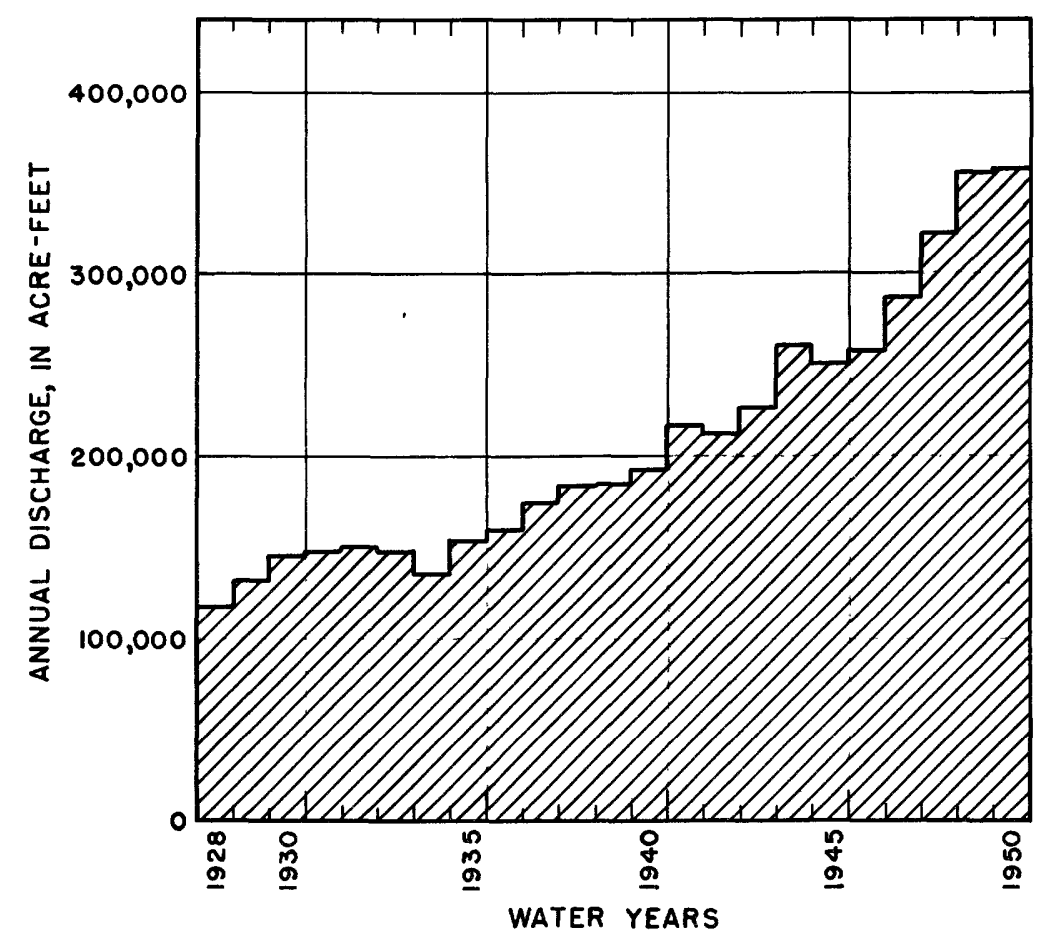

Figure 13. - Annual sewage waste to ocean from metropolitan Los Angeles. 


\section{CULTURAL INFLUENCES ON LOCAL WATER SUPPLY}

In most instances, the cultural developments in the valley areas have tended to reduce the local water reserves. A survey made by the city of Pasadena in 1938 and 1939 showed that 28 percent of that city's area had an impermeable surfacing, such as streets, sidewalks, and roofs of houses (Gleason, 1951, p. 1006). This proportion of impermeable cover increased to 33 percent for certain types of residential areas in this suburban city. Many of these suburban and urban areas now occupy lands which were among the most absorptive in the entire region.

A survey of the Ventura, Santa Clara, Los Angeles, San Gabriel, and Santa Ana River drainage areas in 1932 by the California Division of Water Resources indicated that 20 percent of the $1,450,000$ acres of valley floor lands was already urbanized (Adams and Huberty, 1933). With the population in this area almost doubled since 1932, there is every reason to believe that possibly 30 percent of this area may now be urban. The increase in impermeable surfacing associated with this conversion to urban area probably represents a sizable decrease in the opportunity for ground-water recharge.

With this increase in impervious areas, a corresponding trend in increased flood runoff is to be expected and has become evident in Ballona Creek and the Los Angeles River.

There is considerable apprehension about the possibility of maintaining the local ground-water reserves against the gradual encroachment of the urban development on the natural stream channels. Many of these channels have been completely eliminated and others converted to concrete-lined storm drains. The extremely absorptive character of these natural stream channels was an important factor in the recharge of the local ground-water reserves. Some of these stream channels absorb runoff at the daily rate of 2 to 5 acre-feet per wetted acre (Laverty, 1946, p. 1139). In the more sparsely settled San Jacinto valley about 90 percent of the runoff from the mountain and foothill areas was absorbed in the stream channels crossing the valley floor during the 10-year period of 1940 to 1950 . Other evidence of this stream-bed absorption occurred during the 1938 flood in the San Bernardino Valley. During the month of March 1938, 56 percent of the 350,000 acre-feet of mountain and foothill runoff was absorbed before reaching the lower end of the valley at Prado. Complete urbanization could greatly reduce this recharge to local ground-water storage and increase the waste to the ocean. 


\section{RÉSUMÉ}

Where the weary Spanish colonist of more than 170 years ago found southern California to be a hot, barren, sandy wasteland, almost devoid of water, there is today a thriving agriculture on more than a million acres of irrigated land and a metropolitan population of more than $5,600,000$.

Figure 14 presents the changes in population and water requirements during the past 100 years. During this period the water problems have, from time to time, been greatly aggravated by the very irregular distribution of the precipitation and runoff, such as shown on figures 6,8 , and 9 . For that reason, the recurring wet

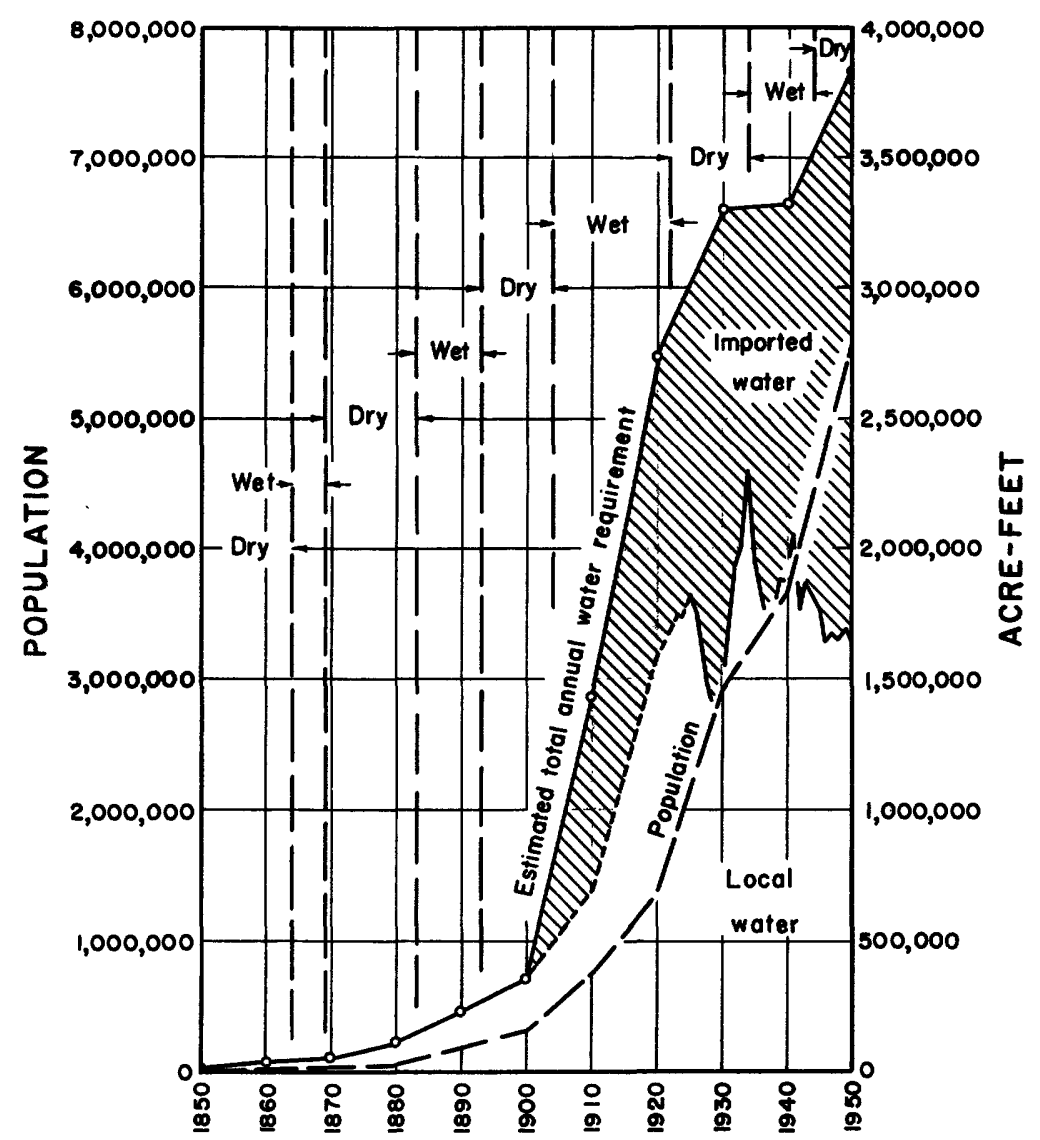

Figure 14.-Population and annual water requirements of southern California. 
and dry periods have also been included on figure 14 . During this 100 -year period there have been 5 predominantly dry periods and 4 predominantly wet periods.

The crosshatched areas on this diagram show the quantity of water imported each year. These imported waters, together with the water developed from local water reserves, have given the water user considerable independence from the variability of the local precipitation.

Because of geographic position and many topographic obstacles, large parts of southern California are not accessible to the sources of imported waters. For these areas the local surface and subsurface reserves are still the only available water supply.

\section{SAN DIEGO REGION}

The San Diego region includes most of San Diego County and is the southernmost part of California lying along the shores of the Pacific. The region includes the drainage areas of all the streams tributary to the Pacific Ocean from the Tia Juana River on the south to the Santa Margarita River on the north, except for those parts in Mexico, as outlined on figure 15. The region consists of broad mountain and highland areas with narrow, shallow alluvial valleys along the main water courses and a narrow belt of flattopped sea terraces along the coast (Ellis and Lee, 1919). The region has an area of about 3,350 square miles of which 85 percent has been classified as mountain and foothill areas.

A cultural survey made in 1912 (California Conservation Commission, 1912) classified about 364,000 acres as potential agricultural lands. In 1951, 90,000 acres were under cultivation, of which about 42,000 acres were in fruit and truck garden crops (Los Angeles County Board of Supervisørs, 1952).

The census data of table 7 indicates that in 100 years the countywide population has increased from 798 in 1850 to 556,808 in 1950 . Because of this phenomenal growth, the population of San Diego County now represents about 5 percent of the State's total population.

\section{WATER REQUIREMENTS}

Most of the water requirements for this rapidly growing population, together with the agricultural and industrial needs, are largely supplied by public and private water agencies. Within the 


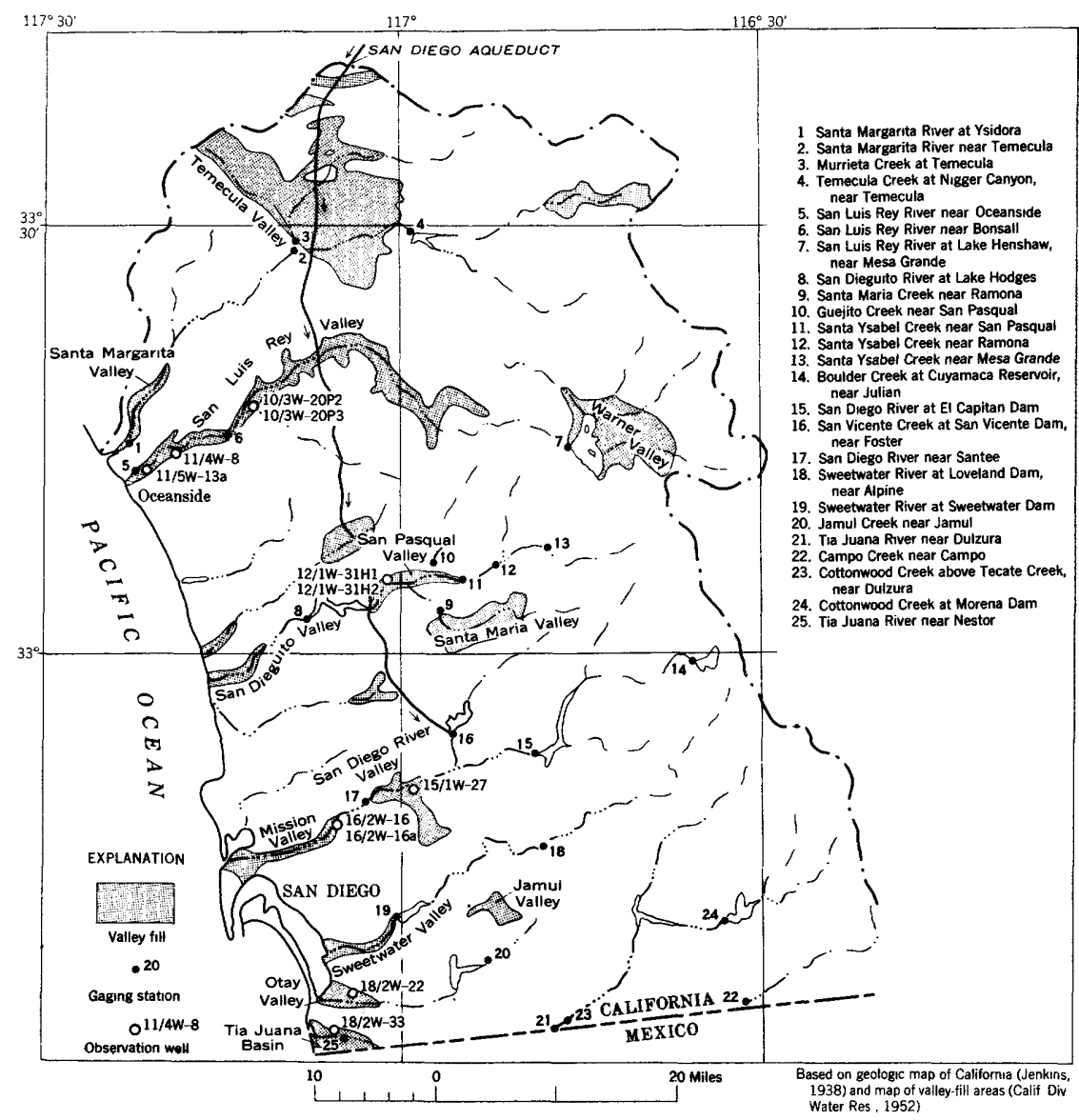

Figure 15.-Map of the San Diego region showing valley fill, observation wells, and gaging stations.

region are 23 water agencies having a potential service area of 185,000 acres.

The largest of these service units is the water department of the city of San Diego whose current urban service area is 66,000 acres. The amount of the annual water deliveries to the residents of the city is given in the lower part of figure 16 for the period 1900-51. Since 1900, the city's annual water requirements have increased from about 2,077 acre-feet to 55,000 acre-feet in 1951 . Because of World War II activities, the annual water requirements increased from 29,000 acre-feet in 1941 to a maximum of 56, 000 acre-feet in 1945. These greatly accelerated water needs created a water shortage that resulted in the organization of a 


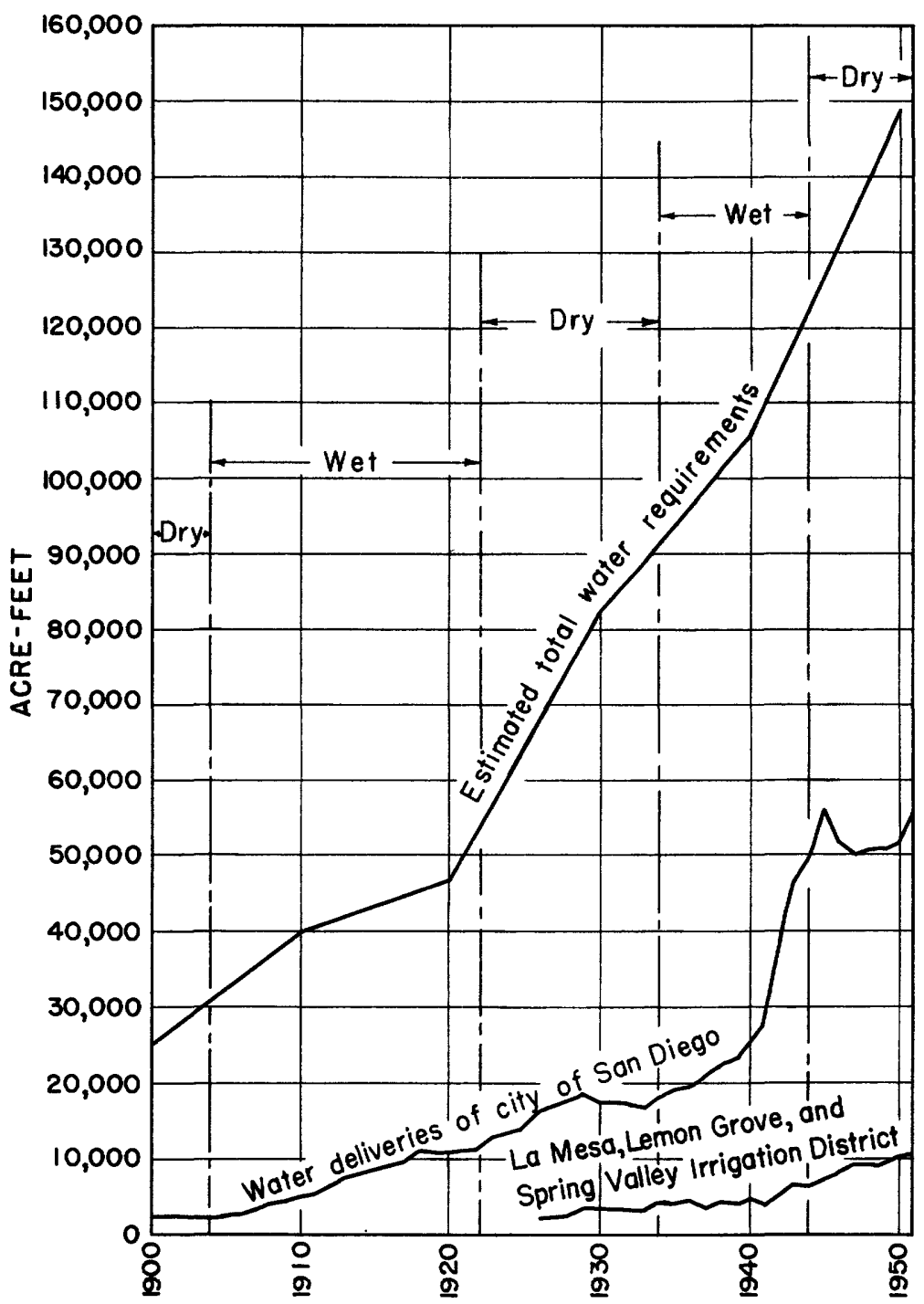

Figure 16. - Estimated annual water requirements of the San Diego region.

conservation program which reduced the deliveries to 50,000 acre-feet in 1947.

The time scale on figure 16 also shows the beginning and ending of the reoccurring wet and dry periods obtained from table 4 and similar tables. During the 1897-1904 drought, the average annual water deliveries to the city of San Diego amounted to 2,400 acrefeet. By the time the next drought of 1922-34 had arrived, these average annual water deliveries had increased 6.9 times to 16,500 
acre-feet. During the final drought shown on figure 16, the average annual water deliveries amounted to 52,400 acre-feet, which is 3.2 times that of the preceding drought. Such a rapid and spectacular increase in average annual deliveries has sorely taxed all the local water reserves available to the city of San Diego.

The annual water deliveries are also shown on figure 16 for La Mesa, Lemon Grove, and Spring Valley Irrigation District for the period of 1926-51. This district is among the larger service units of the region and has a potential service area of more than 19,000 acres. Its annual water deliveries for irrigation, domestic, and industrial purposes has steadily increased from 2, 400 acre-feet in 1926 to 10,460 acre-feet in 1951. Like the city of San Diego, its most spectacular increase in water needs occurredduring World War II.

Fallbrook is another area having a phenomenal increase in water deliveries. Since 1940 deliveries of the Fallbrook Public Utility District have increased from 336 acre-feet to 5, 300 acrefeet in 1951 .

The main purpose of figure 16 , however, is to show the change in the estimated regional water requirements for the period 1900-50. On the basis of census data, the regional annual water requirements have been computed to be about 25,000 acre-feet in 1900 and 149,000 acre-feet in 1950. Such a steadily increasing requirement has made it impossible to satisfy completely all the regional needs from waters originating within the area.

\section{WATER RESERVES}

San Diego regional reserves, both surface and ground water, are completely dependent upon the precipitation which occurs in the area. These reserves are sustained by the annual recharge, which is the amount of precipitation less the sum of the natural water loss and the waste to the ocean. As a result, the residual is often an extremely small part of the precipitation. Ellis and Lee (1919) indicated that the natural water loss consumes from 85 to 94 percent of the precipitation in the San Diego region. An indication of the size of this residual is shown in a report by the State Water Resources Board (1951) that estimates the mean annual regional natural, or undepleted, runoff to be about 290,000 acre-feet, which is equivalent to about 1.6 inches over the entire area. Currently about 150,000 acre-feet of this runoff is wasted to the ocean.

Like the precipitation, the annual runoff is highly variable from year to year. This variability is shown on the upper part of figure 

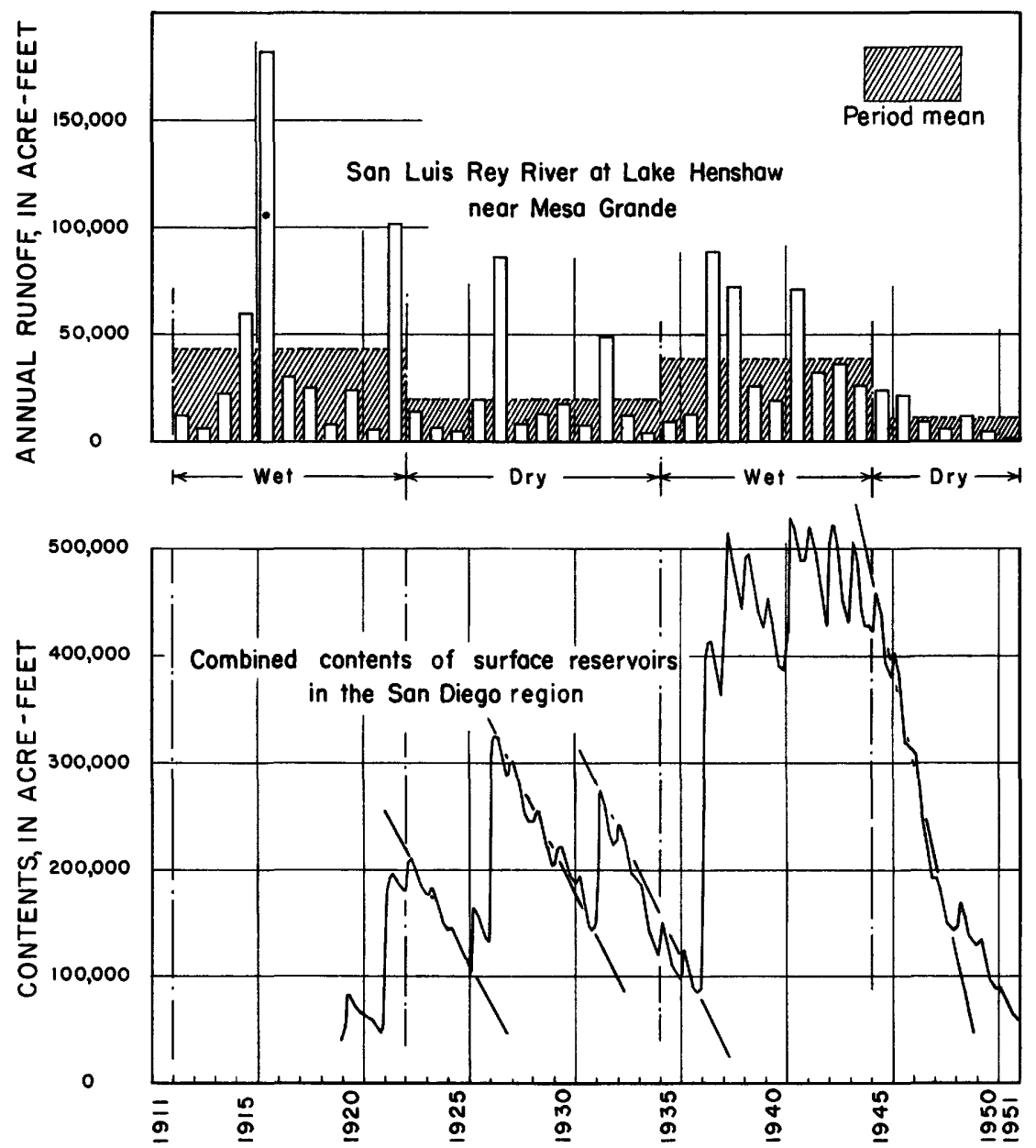

Figure 17. - Annual runoff of San Luis Rey River and combined contents of surface reservoirs in the San Diego region.

17 by the runoff record of the San Luis Rey River at Lake Henshaw near Mesa Grande for the period of 1911-51. The location of this station is at site 7 on figure 15, which also gives the location of many of the other gaging stations in the San Diego region. The annual runoff for ondy 10 individual years exceeded the mean annual runoff of 29,500 acre-feet. Yet these 10 individual years accounted for two-thirds of all the runoff in the 40-year period. Such extreme variability makes complete utilization of all the runoff extremely difficult, as well as impractical.

In conformity with patterns already established in this report, the time scale on figure 17 has been divided into wet and dry 
periods. During the first wet period which ended in 1922 , the average annual runoff was 43,000 acre-feet. In the 12-year drought of 1922-34 which followed, the average runoff declined to 20,000 acre-feet. This drought was concluded by the 10-year wet period which produced an average annual runoff of 39,000 acre-feet. Then came the rather short drought of 1944-51 in which the average runoff decreased to 11,000 acre-feet. This distribution of wet and dry periods is believed to be typical of the runoff throughout the region.

\section{IMPORTATIONS}

To relieve a water shortage, construction was started on the San Diego Aqueduct in the spring of 1945, and by November 1947 water from the Colorado River was being delivered to the San Diego region. The location of this aqueduct and its terminal at San Vicente Reservoir is shown on figure 15. Table 12 gives the

Table 12. - Water imported into the San Diego region from the Colorado River

\begin{tabular}{|c|c|c|c|}
\hline Year & $\begin{array}{c}\text { Imported water } \\
\text { (acre-feet) }\end{array}$ & Year & $\begin{array}{l}\text { Imported water } \\
\text { (acre-feet) }\end{array}$ \\
\hline 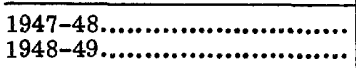 & $\begin{array}{l}41,100 \\
71,600\end{array}$ & 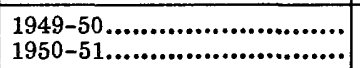 & $\begin{array}{l}69,300 \\
73,900\end{array}$ \\
\hline
\end{tabular}

annual importations since that date. At present, the amount of water imported to the area is limited by the capacity of the San Diego Aqueduct, which can deliver about $100 \mathrm{cfs}$. Construction has recently been started on the "second barrel" of the aqueduct which, when completed, will approximately double the present capacity. It will be noted that by 1950-51 these imports were equivalent to about half of the estimated annual water requirements.

\section{EFFECTS OF DROUGHT OF 1944-51}

Never within the time of man have the water reserves of the San Diego region been so greatly depleted as during the critical drought period of 1944-51. The continual increase in cultural development has produced a water requirement which exceeds the dependable yield of the region. 


\section{SURF ACE WATER}

Early ranchers and other water users in the region built simple brush and dirt dams to divert streamflow by canal or ditch to the point of use. Most of these dams were in areas along the stream channel where high ground-water levels produced cienagas. This method of diversion has been abandoned because of the draining of the cienaga areas and the great variability in the stream flow. Often during the summer irrigation season these streams would completely dry up. In fact, during a sequence of dry years, such as the 1944-51 drought, some streams may cease to flow for a number of years.

The water users soon discovered that the storage of the winter flood runoff from the mountain and foothill, even though it be of a violent nature and of uncertain frequency, offered the most ef fective solution to the water-supply problem. Consequently, Sweetwater and Cuyamaca reservoirs were built in 1887 (sites 19 and 14, on fig. 15). The success of these ventures led to the building of more than 30 similar structures by 1950 , having a combined storage capacity of 730,000 acre-feet, as shown in table 13. This combined storage is equivalent to almost five times the estimated 1950 regional water requirements.

Table 13. - Combined storage capacity of surface reservoirs in the San Diego region.

\begin{tabular}{|c|c|c|c|}
\hline Date & $\begin{array}{c}\text { Capacity } \\
\text { (acre-feet) }\end{array}$ & Date & $\begin{array}{c}\text { Capacity } \\
\text { (acre-feet) }\end{array}$ \\
\hline 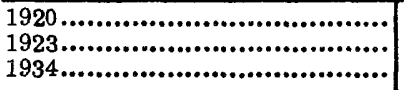 & $\begin{array}{l}186,000 \\
432,000 \\
559,000\end{array}$ & 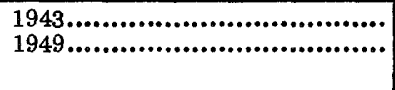 & $\begin{array}{l}651,000 \\
730,000\end{array}$ \\
\hline
\end{tabular}

Most of the storage is confined to the 14 largest reservoirs, which have a combined capacity of 668,000 acre-feet, or about 92 percent of the total capacity. The combined contents of these 14 reservoirs for the period 1920-51 is shown in the lower part of figure 17. The data for this diagram were furnished by the California Water and Telephone Company; City of San Diego; La Mesa, Lemon Grove and Spring Valley Irrigation District; Vista Irrigation District; and Pauba Ranch. In the 31 -year period shown, the maximum contents of these reservoirs was 525, 000 acre-feet in May 1941. This was depleted to 60,000 acre-feet by December 1951.

The contents of the reservoirs represent the cumulative dif ference between the recharge during the winter rainfall period and the depletions necessary to satisfy the water requirements. 
Because of this large reservoir capacity, the recharge from the runoff during a single wet year could exceed the water requirements of the next 5 or 6 years. While there is an immediate increase in the contents during each isolated wet year, it generally takes a series of wet or nearly wet years such as 1937 to 1945 to fill these reservoirs completely.

Surface reservoirs of this type have proven effective in the San Diego region because their combined storage capacities exceed the average annual runoff by 2.5 times. As a consequence, 420,000 acre-feet of runoff, which would have ordinarily wasted to the ocean, was placed in storage during the storm runoff periods in the water years of 1937 and 1938. Such a recharge is almost great enough to supply all the water requirements for a 3-year period. Even during so moderately a wet year as 1932, 133,000 acre-feet was placed in storage in the midst of a predominantly dry period.

At the beginning of the 1944-51 drought there was 460,000 acrefeet in surface storage on April 1, 1945. By December 1, 1947, this storage had declined at a most critical rate to 192,000 acrefeet. Such a decline in storage represents a rate of depletion amounting to about 100,000 acre-feet per year for this $32-$ month period. This depletion was partly arrested in November 1947 by the importation of Colorado River water through the. San Diego Aqueduct. By December 1951 most of the reservoirs were dry or nearly dry, with a combined content of only about 60,000 acrefeet, of which 80 percent was water diverted from the Colorado.

As shown on figure 17, the rate of depletion in storage content has been greatly accelerated since 1940. A rate of depletion of about 42,000 acre-feet per year for the 55-month period of April 1 , 1932 to November 1, 1936 increased to 100,000 acre-feet per year for the 32 -month period in 1945-47. During the 1932-36 period the rate of depletion was about 46 percent of the annual water requirements, and in the $1945-47$ period it was about 76 percent of the annual requirements. This accelerated rate of depletion suggests that a larger and larger share of a continuously increasing requirement comes from surface-water storage. If this trend continues, the existing surface storage will become less and less effective in satisfying the regional water requirement.

\section{GROUND WATER}

Because ground-water storage in the San Diego region is generally confined to the shallow valley fill along the stream channels, the ground-water reserves are very much smaller and generally less effective than those found in other parts of southern California. The 1940 census indicated that the wells in this region 
have the smallest output per acre irrigated of the entire southern California coastal area. As the demand for agricultural and residential acreage increased, venturesome developers have moved into the foothill areas. Many wells have been drilled into the underlying weathered and fractured bedrock to satisfy their water requirements. As a result, hundreds of small ranch and domestic supplies are dependent upon the ground-water storage in the bedrock (Merriam, 1951).

The more important regional ground-water reserves are in the alluvial deposits of such coastal valleys as the Tia Juana, Otay, Sweetwater, Mission, San Dieguito, San Luis Rey, and Santa Margarita and such highland valleys as El Cajon, Santa Maria, Warner, Jamul, and San Pasqual. These valleys are shown on figure 15. The alluvial deposits in these valleys are seldom deeper than 200 feet and the ground water stored in them is largely derived from the winter runoff originating on the adjacent mountain and foothill areas, together with such deep penetration as may occur from precipitation falling directly on the area during the wetter years. The continual changes in water level within these deposits merely reflect the continuous cumulative difference between recharge and extraction, and are shown for certain representative wells on figure 18. The general location of these index wells can be obtained from figure 15. The upper part of figure 18 gives the distribution and magnitude of the annual runoff of Santa Ysabel Creek near Mesa Grande (site 13 on fig. 15) and is included as an index to the recharge of these ground-water reserves.

The water-level records in most of the wells indicate that even in moderately dry years the annual winter recharge was generally sufficient to maintain maximum ground-water storage. Because of this sustained storage, there was little opportunity for additional recharge; consequently, large portions of the runoff available for recharge wasted into the ocean as surface runoff during wet years.

Since the spring of 1944 , the water levels not only failed to recover, but steadily declined because of the combined influences of increasing water requirements and the 1944-51 drought. As a result, the water levels in the fall of 1951 were the lowest of record. By the same token the capacity for recharge is the greatest of record.

In the coastal valleys it is of course necessary for the water levels to be maintained well above sea level in order to keep a favorable ground-water gradient toward the ocean. As indicated on figure 18, water levels reached an all-time low in 1951 and in some wells were below sea level. This tends to create an adverse gradient, resulting in sea water moving inland. As early as 1906 

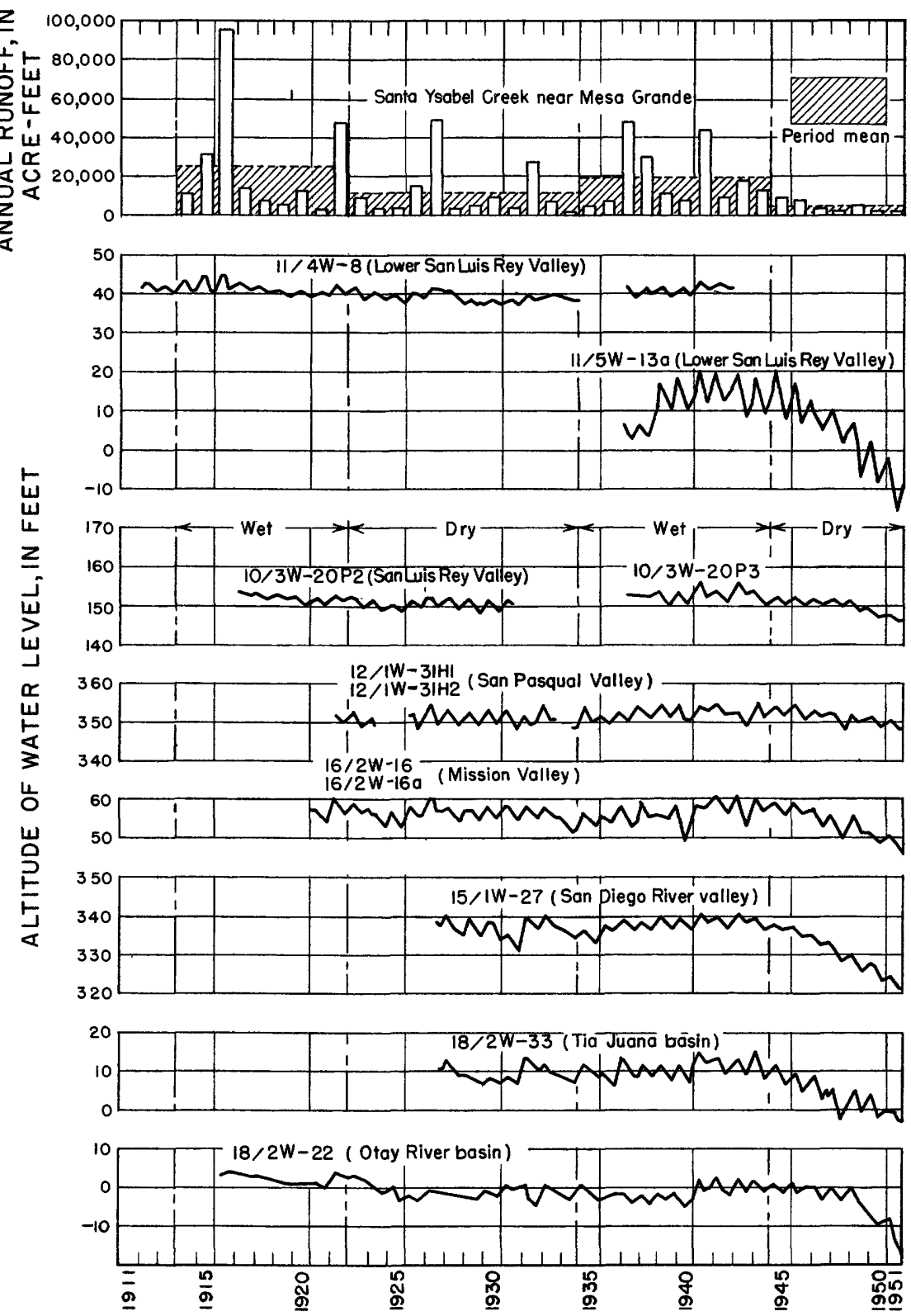

Figure 18. - Annual runoff of Santa Ysabel Creek and altitude of ground water at selected wells in the San Diego region.

sea-water encroachment was noted along the margin of San Diego Bay. At the present time known areas of sea-water encroachment exist in the Mission, San Luis Rey, and Santa Margarita valleys with a threat of sea-water encroachment existing in the Tia Juana 
and Otay valleys (Banks, 1952). For this reason, water levels cannot safely be allowed to remain at the minimum altitudes experienced in 1951 along the seaward margins of these coastal valleys.

\section{LOS ANGELES REGION}

The drainage areas of the Los Angeles, San Gabriel, and Santa Ana Rivers, together with the coastal plain from Newport Beach to Malibu Beach, are designated as the Los Angeles region. This region, shown on figure 19, coincides with Gleason's (1947a) south coastal basin except for the inclusion of the San Jacinto River basin. As thus outlined, the region contains about 4,550 square miles of broad valleys and high mountains. At least 55 percent of the region has been classified as mountain and foothills, and includes the very steep and rugged San Gabriel, San Bernardino, San Jacinto, Santa Ana, and Santa Monica Mountains, which have peaks rising 11,500 feet above sea level. At the foot of these mountain areas are the great alluvial valleys, which include the San Fernando, San Gabriel, and Upper Santa Ana, the San Jacinto basin, and the coastal plain. A cultural survey made in 1912 indicated that in these alluvial valleys there are about $1,200,000$ acres suitable for agricultural purposes (California Conservation Commission, 1912), of which about 435,000 acres are now irrigated.

The 1950 census indicates that $4,760,000$ people, or about 45 percent of the State's entire population, reside in this relatively small region whose population requires an area of about 450,000 to 500,000 acres to satisfy its urban, suburban, and industrial needs.

\section{WATER REQUIREMENTS}

The phenomenal growth in population and in agricultural and industrial development in this semiarid region has made the problem of satisfying the water needs extremely difficult. It has made necessary the maximum and most efficient utilization of all the local reserves, as well as the importation of water from other areas by a multitude of mutual, private, and public service units. The largest of these service units is the water distribution system of the city of Los Angeles. Although its existence has been continuous in one form or another since the founding of the pueblo in 1781 , reliable records of water deliveries were not available until 1919. These records, shown in the lower right corner of figure 20 , indicate that annual water deliveries have steadily increased from 


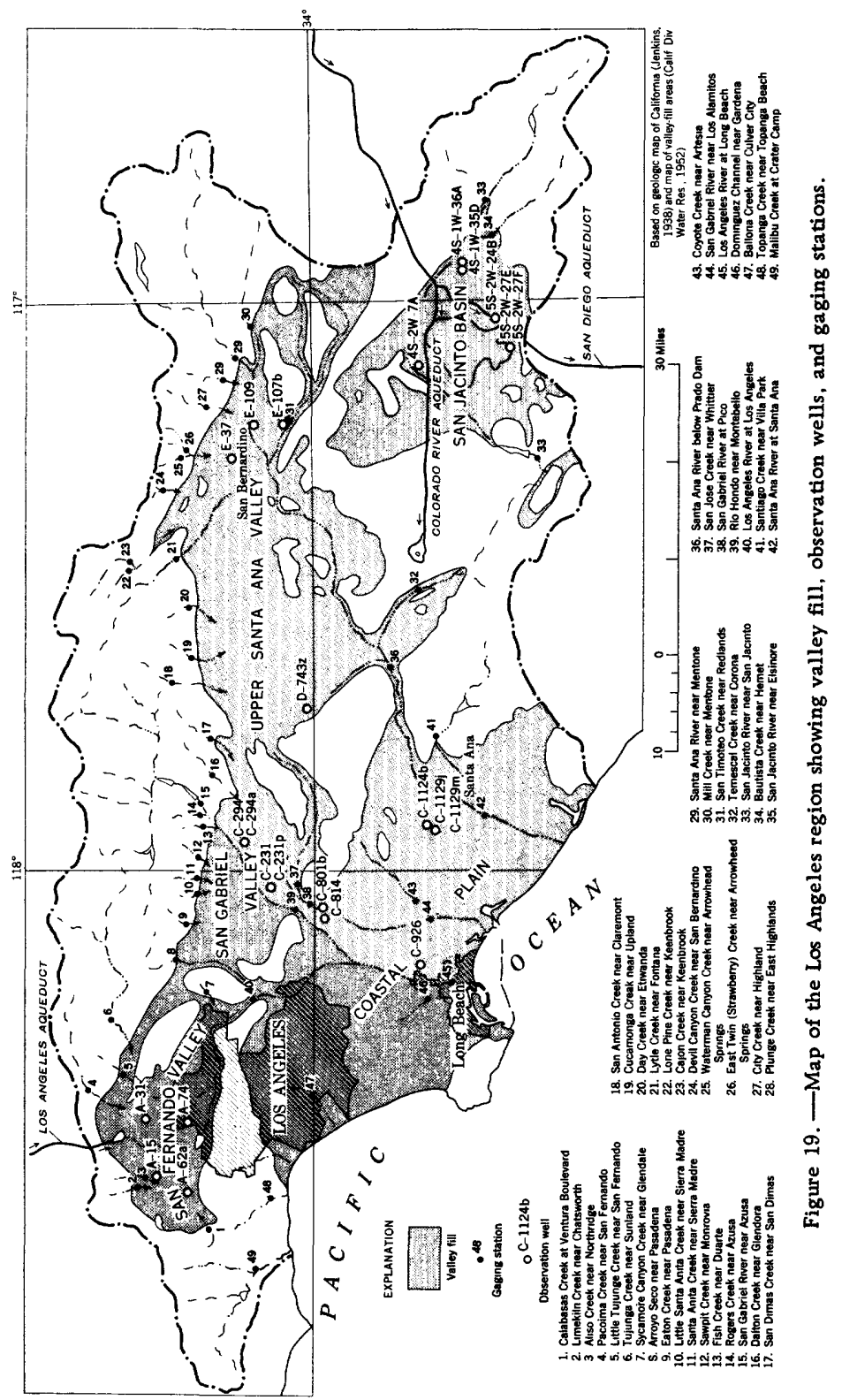




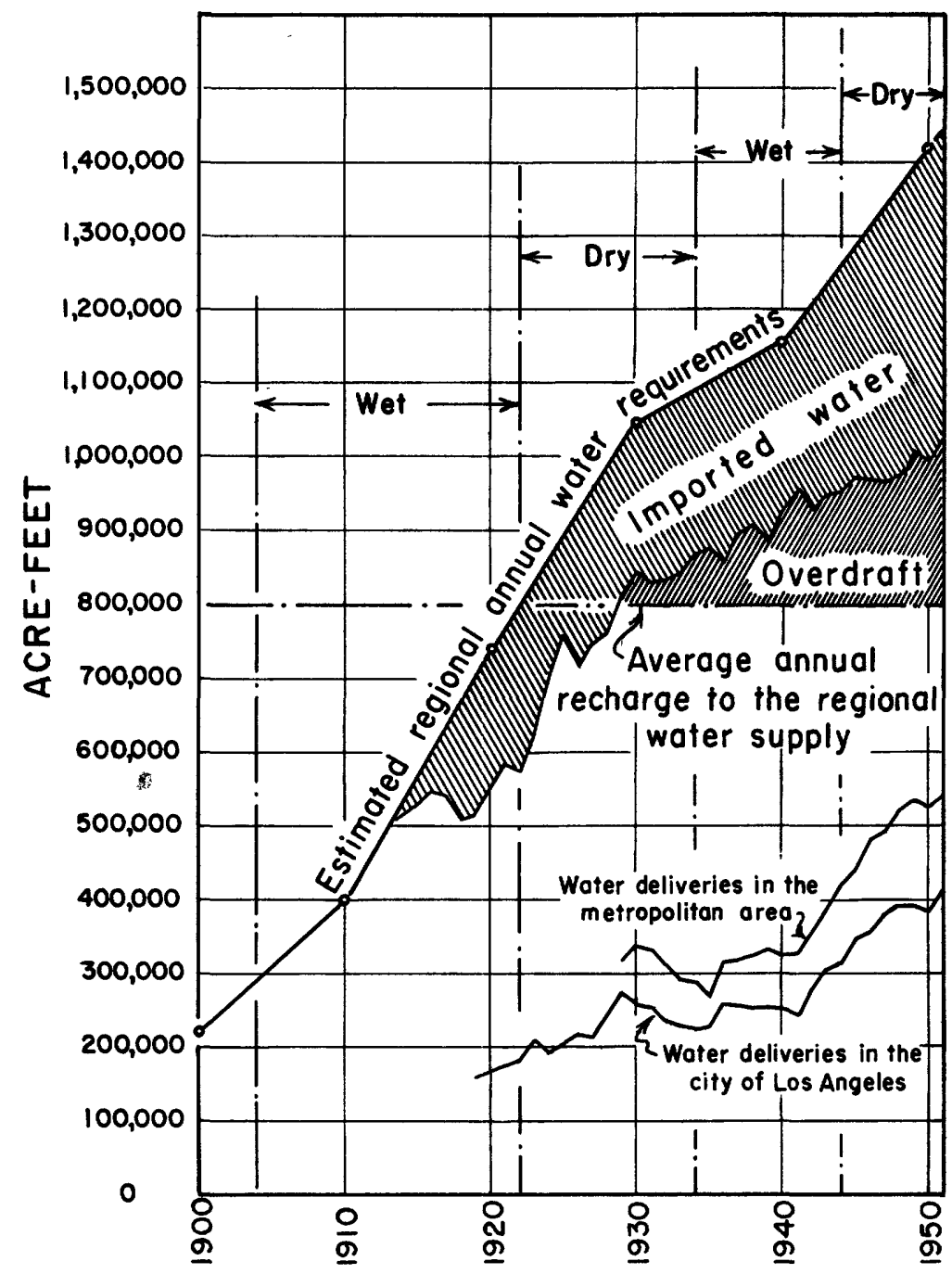

Figure 20. - Estimated annual water requirements of the Los Angeles region.

159,000 acre-feet in 1919 to 415,000 acre-feet in 1951 , an increase of 161 percent in 33 years.

The second graph in the lower right corner of figure 20 gives the combined annual water deliveries to all the member cities of the Metropolitan Water District of Southern California in the Los Angeles region. The Metropolitan Water District supplies all, or part, of the water used in such cities as Anaheim, Beverly Hills, Burbank, Compton, Fullerton, Glendale, Long Beach, Los Angeles, Pasadena, San Marino, Santa Ana, Santa Monica, and Torrance. The record of the combined annual water deliveries to these cities 
tends to parallel that of the city of Los Angeles, and in 1951 deliveries were 541,000 acre-feet.

Figure 20 shows the estimated regional annual water requirements which are the combined agricultural, domestic, and indus trial water needs. These regional water requirements are, and have been, satisfied either from the local reserves or from imported waters. The segregation between these two water sources shown on figure 20 was obtained by subtracting the annual importations from the estimated annual water requirements. Before 1913 all the water requirements were obtained from local reserves; however, by 1951 only 69 percent, or slightly more than 1, 000, 000 acre-feet, was obtained from these local reserves.

In the past 60 years, the first real shortage of water within the region occurred during the very severe drought of 1893-1904. Even though the agriculturist may have found it difficult to satisfy his needs for water during this drought, the regional water requirements increased from 300,000 to 800,000 acre-feet before the next and less severe drought of 1922-34 arrived. In order to survive this second drought, parts of the region found it necessary to resort to extreme water economies, as well as increasing the importation of water. However, by the time the third, or current, drought arrived, the regional water requirements had steadily increased to $1,250,000$ acre-feet in 1944 and $1,450,000$ acre-feet in 1951. In order to satisfy these needs as they arose, it has been necessary grossly to deplete the local reserves, even to the extent of creating an overdraft, as well as increase the water importation.

\section{WATER RESERVES}

In contrast to the steadily increasing water requirements, the regional water reserves have definite limitations, which are further subject to recurring cyclic-like patterns of wet and dry periods. To of fset the lack of precipitation, or runoff, during an extended dry period, water is pumped from ground-water storage or released from surface-water storage. These withdrawals are made on the assumption that the precipitation in subsequent wet periods will completely restore the depleted storage. However, the responsibility of replacing these waters is not firmly fixed, and as a result, a permanent overdraft in the ground-water storage has developed in some parts of the Los Angeles region.

\section{MOUNTAIN AND FOOTHILL AREAS}

Precipitation.-One of the main sources of recharge to the local reserves is the precipitation that occurs in the mountain and foothill 
areas. In these areas the mean annual precipitation ranges from about 15 inches in the coastal foothill areas to more than 45 inches along the divide of the San Gabriel, San Bernardino, and San Jacinto Mountains. Regional isohyetal maps prepared by Stafford and Troxell (1953) indicate that on an areal basis the mean annual precipitation within these foothill and mountain areas will be about 24 inches and have a region-wide volume of $3,100,000$ acre feet. The annual departures from this mean value, and their time sequences, were based on the annual precipitation observed at the Bear Valley Dam, Raywood Flats, Squirrel Inn, Camp Baldy, and Mount Wilson stations. The magnitude and distribution of this regional annual precipitation is given in the upper part of figure 21 for the period 1920-51. In this 31-year period, 6 individual years, or 19 percent of the time, contained 31 percent of all the precipitation; while 14 individual years, or 45 percent of the time, contained almost 60 percent of the total precipitation, a distribution typical of most of southern California.

The sequence shown on figure 21 falls into two dry and one wet period, based on table 4 and similar data. The precipitation during the first dry period of $1922-34$ had a region-wide average annual volume of $2,600,000$ acre-feet. Yet within it there were 3 relatively wet years in which the annual precipitation exceeded the mean value of $3,100,000$ acre-feet.

The average annual regional precipitation decreased slightly to 2, 500,000 acre-feet during the last or current drought of 194451. While containing the driest year in the 31-year period, this 7 -year drought included 2 years in which the precipitation slightly exceeded the mean.

In contrast the wet period of $1934-44$ had an average regional precipitation in the mountain and foothill areas of $3,600,000$ acrefeet. Even in this 10-year period there were 3 years with less than the mean precipitation.

Runoff.-This mountain and foothill precipitation; after satisfying the average annual natural water loss, produced a mean annual runoff of about 500,000 acre-feet onto the valley floor areas around the periphery of the main valleys. This regional mountain and foothill runoff was based on the records obtained at a series of gaging stations located around the periphery of the valley floor area as shown on figure 19, supplemented by the estimated runoff from the unmeasured areas between these drainage areas. The mean annual runoff thus obtained was equivalent to 3.9 inches over the mountain and foothill areas, or about 16 percent of the precipitation, and represents the total recoverable waters from these areas under current conditions. On reaching the valley floor, part 


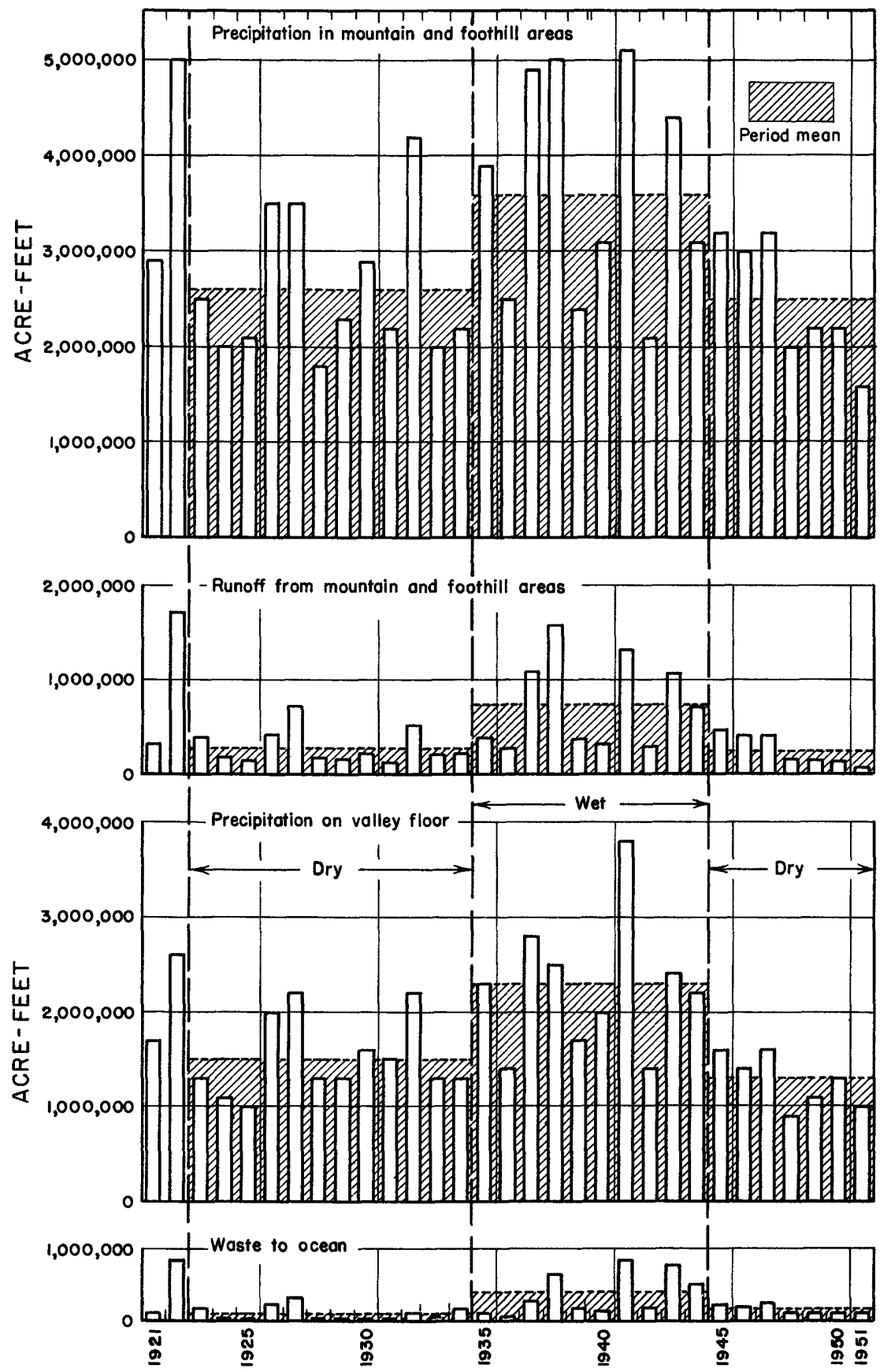

Figure 21. - Annual precipitation and runoff in the Los Angeles region. 
of these recoverable waters is wasted to the ocean during flood periods, while other parts are absorbed into the stream-channel debris of the valleys to recharge ground-water reserves, or are diverted for domestic, industrial, and agricultural uses.

The annual distribution of the regional mountain and foothill runoff for the period 1920-51 is given in the midpart of figure 21 . It becomes very clear that the variability of the precipitation distribution is present in a more exaggerated form in the records of runoff. Five individual years, or 16 percent of the time, contained 45 percent of the runoff, while 8 individual years representing 26 percent of the time contained 59 percent of the runoff.

This regional mountain and foothill runoff has also been segregated into the wet and dry periods used throughout this report. During the 1922-34 drought the average runoff amounted to 290,000 acre-feet. In this dry period only 2 of the 12 years had a runof in excess of 500,000 acre-feet, while 5 years had an annual runoff of less than 200,000 acre-feet.

The drought of 1944-51 was even drier, with an average annual regional runoff of 270,000 acre-feet. In this 7-year period none of the years had a runoff in excess of 500,000 acre-feet, but 4 years had a runoff of less than 200,000 acre-feet.

In contrast, the wet period of 1934-44 had an average annual regional runoff of 740,000 acre-feet, or more than 2.5 times greater than either of the drought periods, with 4 years having an annual runoff in excess of 1,000,000 acre-feet.

\section{VALLEY FLOOR AREAS}

Precipitation. - In addition to the runoff from the mountain and foothill areas, precipitation on the valley floor frequently makes considerable contribution to the local water reserves. Stafford and Troxell (1953) indicate the average annual precipitation in the valley-floor areas ranges from 10 inches in the San Jacinto valley to 20 inches along the contact with the San Bernardino and San Gabriel Mountains and has an average regional value of about 16 inches, or a volume of $1,800,000$ acre-feet. The annual sequence and departures from this mean were based on the precipitation recorded at Los Angeles, Long Beach, Santa Ana, San Fernando, Pasadena, Ramona, San Bernardino, and San Jacinto. The magnitude and time distribution of the regional values are shown in the lower part of figure 21. In many ways this distribution is similar to that already shown for the mountain and foothill areas. 
During the 12-year drought of 1922-34 the average annual regional precipitation amounted to $1,500,000$ acre-feet. However, in the dry period of 1944-51 this average decreased to $1,300,000$ acre-feet. In the intervening wet period the average annual precipitation was $2,300,000$ acre-feet.

Waste to ocean.-Of all the precipitation on the valley floor and mountain areas of the region, only about 4 percent, or 180,000 acre-feet, wastes annually to the ocean through natural water courses. The lowermost diagram on figure 21 gives annual distribution of this waste into the ocean. It is based on the combined annual runoff of the Santa Ana, San Gabriel, and Los Angeles Rivers, Ballona and Topanga Creeks, and Dominguez channel. Gaging stations are shown on figure 19. Most of this waste occurs during flood years; 56 percent of the total waste occurred in 5 individual years, or 16 percent of the time.

The annual regional waste to the ocean during the 1922-34 drought was 79,000 acre-feet. Then, largely because of cultural changes, this annual regional waste increased to 110,000 acre-feet during the current dry period of 1944-51. During the intervening wet period of $1934-44$ this annual waste amounted to 300,000 acre-feet.

\section{RECHARGE OF LOCAL WATER RESERVES}

The regional recharge to the local water reserves is mostly that part of the precipitation falling on the valley-floor areas and penetrating below the root zone of the plant cover, plus the recoverable water from the mountain and foothill areas. It is always essential to the well-being of the community for the average annual recharge to these reserves through long periods of time to equal the average annual extractions over the same period. For this reason table 14 has been prepared to show the average annual recharge for the 29 year period 1922-51. Many of the data on which this table is based are shown in figure 21.

The first item in this table gives the recoverable water that originates in the foothill and mountain area and that is available to the valley floor for the two dry and one wet period between 1922 and 1951. The remaining four items refer to waters originating on the valley-floor areas. The first item gives the precipitation falling on the valley floor, as obtained from the data on figure 21 . The second item shows that part of the precipitation lost through interception and evaporation from the leaves of the vegetative cover during and immediately after a rainstorm, as well as the evaporation from the soil. Such moisture, the equivalent to about 
Table 14.-Estimated annual recharge, in acre-feet, to the local water supply of the Los Angeles region

\begin{tabular}{|c|c|c|c|}
\hline & $\begin{array}{c}\text { Dry period } \\
1922-34\end{array}$ & $\begin{array}{c}\text { Wet period } \\
1934-44\end{array}$ & $\begin{array}{c}\text { Dry period } \\
1944-51 \\
\end{array}$ \\
\hline 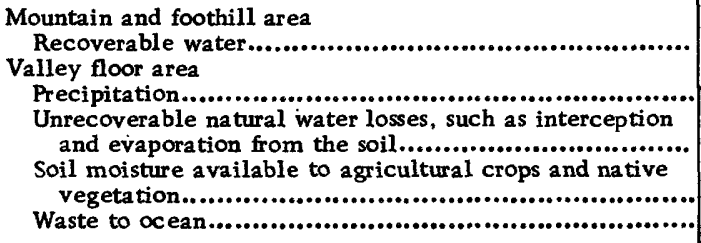 & $\begin{array}{r}290,000 \\
1,500,000 \\
-500,000 \\
-760,000 \\
-79,000\end{array}$ & $\begin{array}{r}740,000 \\
2,300,000 \\
-500,000 \\
-1,070,000 \\
-300,000\end{array}$ & $\begin{array}{r}270,000 \\
1,300,000 \\
-500,000 \\
-650,000 \\
-110,000\end{array}$ \\
\hline 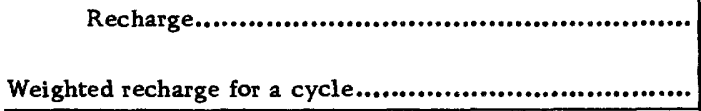 & $\sqrt{780,000}$ & $1,170,000$ & 310,000 \\
\hline
\end{tabular}

4 inches over the valley floor, is lost to the region and is neither available for recharge of the soil moisture in the root zone of the plant cover nor for recharge of the surface- and ground-water supplies.

The third item under "Valley floor area" of table 14 represents the estimated average annual regional recharge to the soil moisture in the rootzone of plants to replace moisture lost through transpiration. It is estimated on the basis of a regional crop survey, soil moisture deficiencies at the end of the preceding summer growing season, and the consumptive use of individual crops, and ranges from the equivalent of 6.7 inches per year during the 194451 drought to 11.1 inches during the 1934-44 wet period. This water remains as soil moisture and, consequently, is not available for recharge to ground-water storage or surface runoff.

The last item, "Waste to the ocean," was obtained directly from the data on figure 21.

The algebraic sum of all the items in table 14 gives the regional average annual recharge to the local water reserves during 2 dry and 1 wet period. In the first dry period of 1922-34, the average annual recharge amounted to 450,000 acre-feet and decreased to 310,000 acre-feet for the second dry period of 1944-51. During the intervening wet period, the average annual recharge increased to $1,170,000$ acre-feet.

An estimate of the average annual recharge to the local regional water reserves can only be obtained by a judicious selection of an observational period where the wet and dry years occur in normal balance. Under these conditions the time period should contain equal numbers of predominantly wet and dry periods. For example, 
it would hardly be logical to select the 29-year period of 1922-51, because this time period would contain 2 dry periods and 1 wet period. As a result the dry years would greatly predominate and be completely out of proportion to the normal distribution. A more logical approach would be the selection of adjacent wet and dry periods such as the 22-year period of 1922-44. Such an observational period would give an average annual regional recharge of 780,000 acre-feet. A second period-that of 1934-51-would give give an average annual recharge of 820,000 acre-feet.

On the basis of these two determinations, the regional average annual recharge has been estimated at about 800,000 acre-feet. This represents the estimated safe yield of the surface-and ground-water reserves of the Los Angeles region under current conditions of development. When the annual water use continuously exceeds this safe yield, then the reserves are overdrawn.

\section{OVERDRAFT}

In attempting to satisfy all the water requirements, it has been necessary to exceed the safe yield and create an overdraft in parts of the Los Angeles region. As indicated on figure 20, this annual estimated overdraft began about 1929 and increased to more than 230,000 acre-feet in 1951. This overdraft of 1951 is equivalent to about 16 percent of the annual water requirements and will steadily increase unless there is a corresponding increase in the amount of water imported from outside the region.

\section{EFFECT OF DROUGHT OF 1944-51}

During the entire 29-year period of 1922-51, the total precipitation in the mountain, foothill, and valley floor areas was 135 million acre-feet. However, after satisfying the regional natural water loss only about 14 percent or 19 million acre-feet remained as a recharge to the surface or ground-water reserves. This recharge was augmented by the importation of 7.6 million acre-feet from the Owens Valley and the Colorado River. In contrast to these total water resources of 26.9 million acre-feet, the regional water requirements amounted to 33 million acre-feet. This leaves a deficiency of 6.2 million acre-feet and represents an estimate of the depletion of the local water reserves since October 1922.

This depletion of the regional water reserves is given in greater detail in table 15 and is shown on figure 22. During the 12-year drought of $1922-34$, the regional water reserves were estimated to have been depleted by $3,990,000$ acre-feet. The upper part of 
Table 15. - Relation, in acre-feet, of local water reserves to water requirements in the Los Angeles region

\begin{tabular}{|c|c|c|c|}
\hline & $\begin{array}{c}\text { Dry period } \\
1922-34 \\
\text { (12 years) }\end{array}$ & $\begin{array}{c}\text { Wet period } \\
1934-44 \\
(10 \text { years })\end{array}$ & $\begin{array}{c}\text { Dry period } \\
1944-51 \\
\text { (7 years) }\end{array}$ \\
\hline 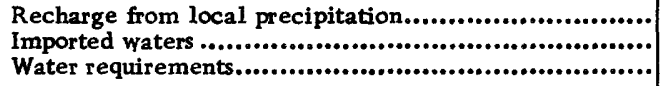 & $\begin{array}{r}5,400,000 \\
2,440,000 \\
-11,830,000\end{array}$ & $\begin{array}{r}11,700,000 \\
2,530,000 \\
-11,660,000\end{array}$ & $\begin{array}{r}2,170,000 \\
2,620,000 \\
-9,550,000\end{array}$ \\
\hline Change in reserve & $-3,990,000$ & $+2,570,000$ & $-4,760,000$ \\
\hline
\end{tabular}

figure 23 shows that the average annual water requirements exceeded the combined recharge to the local supply and.imported waters, leaving a deficiency.

In the subsequent wet period, the combined imports and recharge to local reserves exceeded the regional water requirements. This surplus reduced the total deficiency since October 1922 to $1,420,000$ acre-feet. Had this 10-year wet period been longer or had it contained greater precipitation, the deficiency would have been considerably smaller.

Once again, during the 7-year drought of 1944-51, the average annual water requirements of $1,360,000$ acre-feet exceeded the combined average annual local recharge and imported waters by 680,000 acre-feet. This additional draft on the water reserves increased the deficiency since October 1922 to $6,180,000$ acrefeet by September 1951.

Of course this depletion should not be considered as a measure of the overdraft. The actual overdraft can only be obtained upon completion of the cyclic trend in precipitation at the end of the next wet period. Any lack of recovery at the end of this next wet period could be a measure of the overdraft since 1922 .

\section{SURFACE WATER}

The combined flow in all the mountain and foothill streams discharging onto the valley floor areas represents the potential surface-water reserves. This runoff originates from two immediate sources: the storm precipitation and the natural drainage from mountain ground-water storage. Because of this latter source, many mountain streams will flow continuously, even during extended dry periods. Continuous flow of this type is in great demand for satisfying many of the regional water requirements. It is estimated that about 200,000 acre-feet of water is diverted annually around the periphery of the valley floor areas for this purpose. 


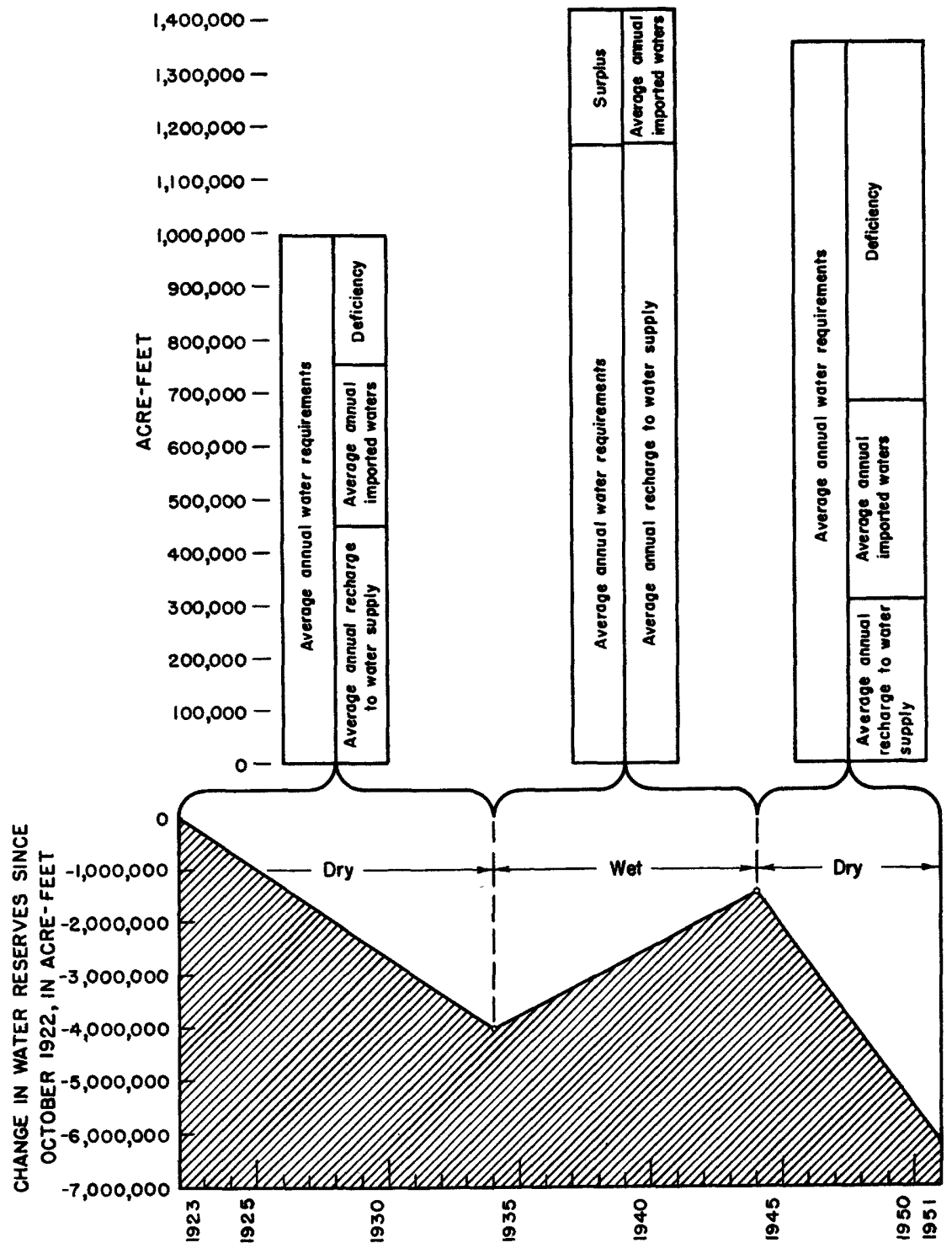

Figure 22. - Changes in the water supply of the Los Angeles region.

However, in most mountain areas, the major part of the runoff occurs during or immediately following the winter rainstorms. Large parts of this storm runoff are converted to valley groundwater storage bystream-bed absorption into the porous debris deposits around the periphery of the valley. But, as indicated in table 14 and figure 21, not all of this storm runoff is absorbed, because 
sizable quantities of water are wasted into the ocean. In an effort to salvage this waste, mountain reservoirs have been built within the region.

The oldest, and possibly the most important, of these reservoirs is the one built in Bear Valley of the San Bernardino Mountains about 1883. Because of its long period of operation, the record of contents in this reservoir from 1884 to 1951 is shown on figure 23. During the first part of this record the reservoir had a

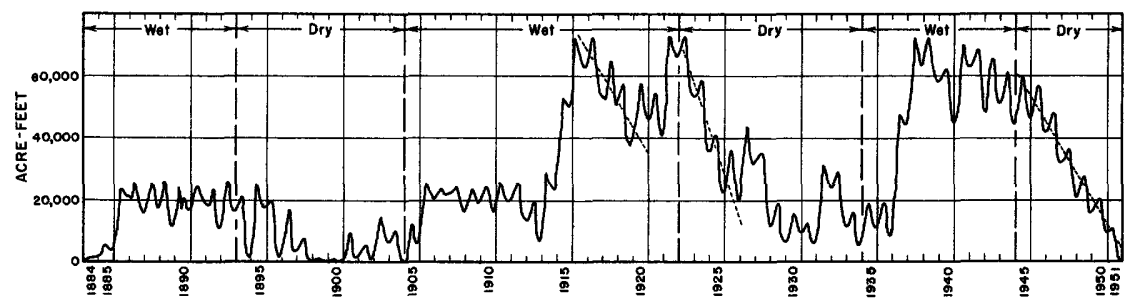

Figure 23. - Contents of Big Bear Lake.

capacity of about 25,000 acre-feet, which was increased during 1911 to 72,400 acre-feet. Consequently the contents during the first phase can not be compared directly to the second phase.

During the second phase of this record, the reservoir was completely filled on three occasions: namely, the wet years of 1916$17,1922-23$, and 1938-39, and nearly filled in 1941. In the drier periods that followed, this accumulated storage was depleted at the rate of about 8,000 acre-feet per year, except during the period between 1922 and 1928 when the rate appears to have increased to about 14,000 acre-feet per year.

As a result of depletions during the drier years, the reservoir was completely dry in $1898,1899,1900$, and 1904 . Since the enlargement of the reservoir, the minimum water storage was $850^{\circ}$ acre-feet in November 1951.

\section{GROUND WATER}

By far the major portion of the region's water reserves are confined to the ground water stored in the alluvial deposits of the five principal valley floor areas. These include the San.Gabriel Valley, the Upper Santa Ana Valley, the San Jacinto basin, the San Fernando Valley, and the coastal plain, all of which are shown on figure 19. In addition to these alluvial deposits, this map shows 
the locations of the Los Angeles and the Colorado River Aqueducts and selected key observation wells.

SAN GABRIEL VALLEY

The San Gabriel is a broad alluvial valley between the toe of the San Gabriel Mountains on the north and the San Jose and Puente Hills to the south. Eckis (1934) found this alluvial fill to range from a few feet to more than 2,000 feet in the deepest parts. He further estimated that these alluvial deposits would contain about $1,171,000$ acre-feet of water in a 100-foot zone extending from 50 feet above to 50 feet below the water levels of January 1933 .

The water level in these alluvial deposits tends to rise and fall during each year, as well as from year to year, and is dependent upon the balance between the recharge and extractions. The records of water levels in well C-294 and its companion well C-294a in the San Gabriel Valley are shown in figure 24 as being typical of the entire valley. The location of these wells is shown on figure 19.

Plotted immediately above these water-level records is a diagram giving the annual runoff of the San Gabriel River at the mouth of the canyon before discharging onto the plains of the San Gabriel valley (site 15, fig: 19).

It will be noted that during each year of unusually large runoff, there is an immediate response in the ground-water levels. During dry years, the meager recharge from winter precipitation and mountain runoff is greatly exceeded by the extractions from ground-water storage during the summer growing season. As a consequence, the water levels decline over extended periods when the dry years predominate and recover over equally extended periods in which the wet years predominate. This gives the records a cyclic pattern not unlike the cumulative departure curves on figures 6 and 8.

At Baldwin Park, in the upper part of the valley, the maximum water level in wells C-294 and C-294a occurred in the spring of 1916. Then as a result of the dry years which followed, the extractions greatly exceeded the recharges, with the result that the water levels were depleted to a minimum in the fall and winter months of 1931. Consequently, in order to satisfy the water requirements during this extended dry period, it was necessary to deplete the ground-water reserves in the vicinity of these wells by 72 feet since the spring of 1916 . 
In the wet years that followed, the annual recharge greatly exceeded the extraction. Consequently, by the spring of 1943 the water rose about 68 feet to a level only about 4 feet less than that observed in 1916. This almost complete recovery indicates that the ground-water reserves had not been overdrawn during the intervening period.
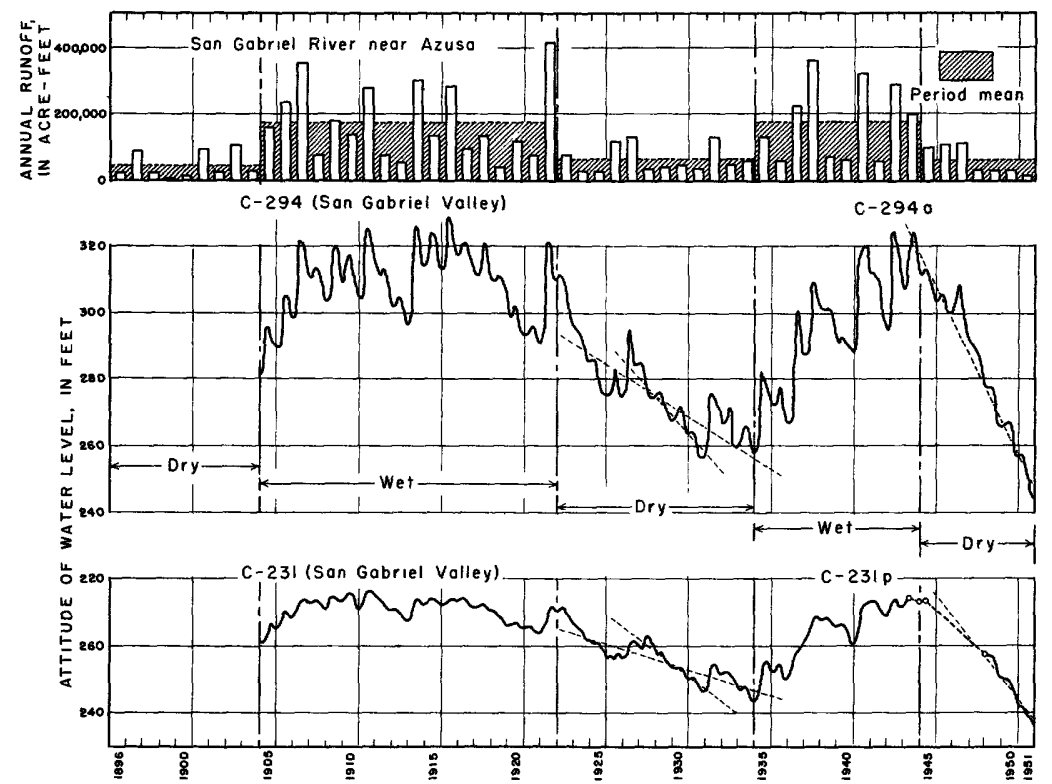

Figure 24. - Annual runoff of the San Gabriel River and altitude of ground water at selected wells in the San Gabriel valley. 
However, in the dry period that followed this recent recovery, the water levels were again declining but at an accelerated rate. In the very short 7 -year drought of 1944-51, the water levels declined almost 80 feet to the minimum altitude for the entire period of record.

During the preceding 12-year drought of 1922-34, the water level in these wells indicated a general decline of about 3.1 feet per year, as shown by a dashed line on figure 24. However, within this drought, there were short periods of time when the rate of decline exceeded this general rate. For example, during the very dry 4-year period of 1927-31 the rate of decline increased to 5.4 feet per year, as also indicated on figure 24 .

In the drought of $1944-51$, this rate of decline reached a maximum of 9.9 feet per year. Such a steadily increasing rate of decline during succeeding dry periods indicates a greater and greater disparity between water requirements and the recharge to the ground-water reserves. It is apparent that if this condition continues, it will be more difficult to restore the 1916 or 1943 water levels in these wells during subsequent wet periods.

The records obtained at well $\mathrm{C}-231$ and its companion well C-231p near El Monte confirm in almost every detail the data obtained at the Baldwin Park wells. A decline in water level of 3.8 feet per year during the period 1927-31, within the preceding drought, increased to 6.2 feet per yearduring the 1944-51 drought. This accelerated rate of decline in water levels clearly suggests a rapid increase in the water requirements in this area. Both these records further suggest that water use in the San Gabriel valley may be rapidly approaching overdevelopment.

\section{UPPER SANTA ANA VALLEY}

The large alluvial valley along the southern toe of the San Gabriel and San Bernardino Mountains extending from Pomona on the west to Mentone on the east has been designated the Upper Santa Ana Valley. The valley's southernboundary is very irregular, being formed by the Crafton Hills, Yucaipa and Beaumont plains, Temescal plateau, and other minor hills. Eckis (1934) has indicated that the depth of the alluvial deposits exceeds 1,000 feet in parts of the valley. He also estimated the ground-water storage capacity of the valley to be 2,580,000 acre-feet for a 100-foot zone extending from 50 feet above to 50 feet below the water levels of January 1933.

Typical water-level records obtained at four wells in the valley are given on figure 25, together with the record of annual runoff of 

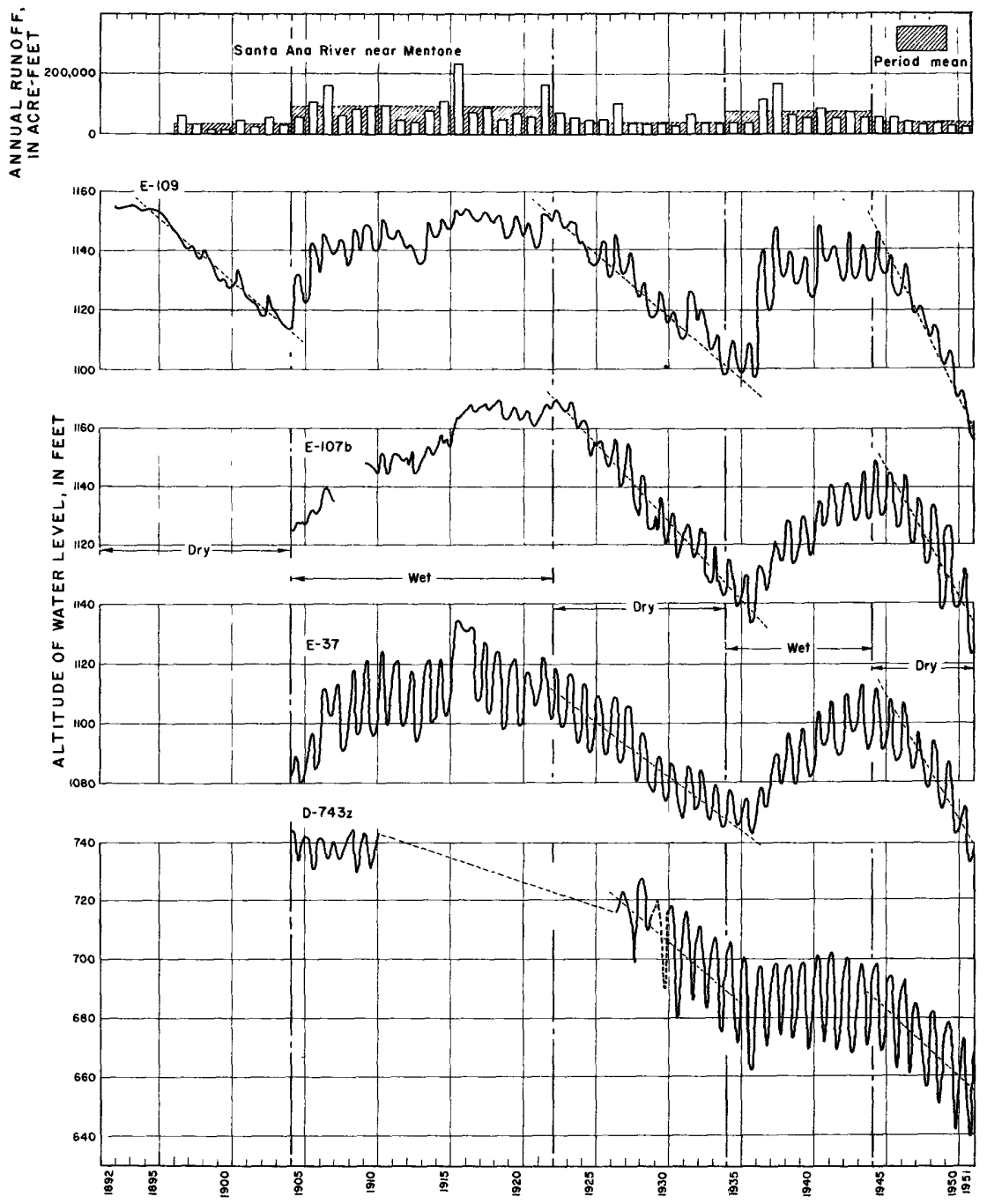

Figure 25. - Annual runoff of the Santa Ana River and altitude of ground water at selected wells in the Upper Santa Ana Valley.

the Santa Ana River as it discharges into the valley. The locations of these key wells and the gaging station are shown on figure 19. In a general way the sequence of annual recharge and depletion of the ground-water reserves follow the same pattern as that already described for the San Gabriel valley.

The record of water level in the Williams well (E-109), located along the Santa Ana River midway between Redlands and San Bernardino, is believed to be the longest available record in the 
Upper Santa Ana Valley. Water-level observations were begun at this well in 1892 and have been continued through 1951. During this 60-year period the valley has experienced three droughts.

During the first of these droughts the water level declined from the top of the casing, 3.8 feet above ground surface, to 43 feet below. This steady decline in water levels throughout the valley created considerable apprehension among water users. At their request Walter C. Mendenhall (1905d) of the Geological Survey prepared a hydrologic report on the area. In this report Mendenhall warned the residents of the valley that the ground-water reserves were being depleted.

The drought was gradually alleviated, however, by the wet years that followed, and by the spring of 1916 the water levels had almost completely recovered. Then, during the drought of 1922-34 water levels again declined, reaching a new low of 58 feet below the 1892 level. The increased precipitation of 1936 again changed the trend in water-level behavior. In the wet years that followed, the water level was once again restored to within about 6 feet of the 1892 level. Then the drought of 1944-51 occurred. During this sequence of dry years, the water level declined to a new low of 79 feet below the 1892 level.

During the first drought of this 60-year period of record, the water level in this well declined at the rate of 4.2 feet per year, as indicated on figure 25. In the second drought, this rate of decline was the same-4.2 feet per year. However, in the third drought, this rate of decline increased to an all-time high of 10.4 feet per year, or 2.5 times as rapid a depletion as in the earlier droughts.

Such rapid increases in the rate of decline of the water levels during periods of little or no recharge tend to indicate a substantial increase in the local water requirements. Consequently, it will be more and more difficult to recharge fully these important reserves. The record also suggests that this area may be overdrawing its water reserves.

These findings are largely confirmed by two additional but shorter records obtained at wells E-37 near San Bernardino and E-107b near Loma Linda, and shown on figure 25. Both of these records clearly indicate the difficulties involved in attempting to maintain these ground-water reserves in the face of everincreasing water requirements. In the spring of 1944 and 1945 the water levels in these wells were more than 20 feet below the high levels in 1916 or 1923. This would suggest at least the first stages of overdraft in the vicinity of these wells. 
In both of these records the rate of decline in the water levels during succeeding droughts has rapidly increased. The rate of decline at well E-37 (fig. 25) increased from 3.8 feet per year for the 1922-34 drought to 8.6 feet per year for the 1944-51 drought. Likewise, at well E-107b the rate of decline increased from 5.3 feet per year in the first drought to 8.7 feet per year in the latest drought. These patterns of ground-water fluctuationare in complete conformity with the basic distribution in regional water reserves shown in the lower part of figure 22 .

The status of the ground-water reserves in the western end of the valley is completely dissimilar to those near San Bernardino and Redlands. As shown on figure 25, the water level in well $\mathrm{D}-743 \mathrm{z}$, which is west of Chino, has declined fairly steadily since 1904. The record indicates that the decline in storage was only momentarily interrupted even during the periods of maximum recharge during the wet periods. Such a consistent lack of noticeable recovery in the water levels clearly indicates a condition of overdraft. As long as this condition continues, the water levels will continue to decline until the individual wells "runs dry."

\section{SAN JACINTO BASIN}

The San Jacinto basin is the combination of alluvial valley floor areas, the land surfaces of which are tributary to the San Jacinto River above Lake Elsinore. This irregular 187-square-mile area includes the San Jacinto valley, Pico-Hemet, Lakeview-Nuevo, Perris Valley, Winchester, and Menifee subbasins. Records obtained at representative wells in four of these subbasins are shown on figure 26, and their locations are shown on figure 19.

Water-level observations have been obtained, since the spring of 1904, at well $4 \mathrm{~S}-2 \mathrm{~W}-7 \mathrm{~A}$ in the Lakeview-Nuevo subbasin. The water level in this well (lower part of fig. 26) has steadily declined since the winter of 1915-16. At the conlcusion of the 190422 wet period, the water level had declined 7 feet below the maximum of 1904 . In the 1922-34 drought that followed, the decline was accelerated to 2.2 feet per year. However, with the conclusion of the 1922-34 drought, the water level continued to decline at a somewhat lesser rate, even though the recharge was very much greater throughout the 1934-44 wet period. The waterlevel decline was again accelerated by the 1944-51 drought. During this drought the rate of decline increased to 4.7 feet per year.

Records of this type generally indicate that the water extractions greatly exceed the recharge. A situation of this nature is clearly a case of exploitation and overdraft, and the water shortage will 


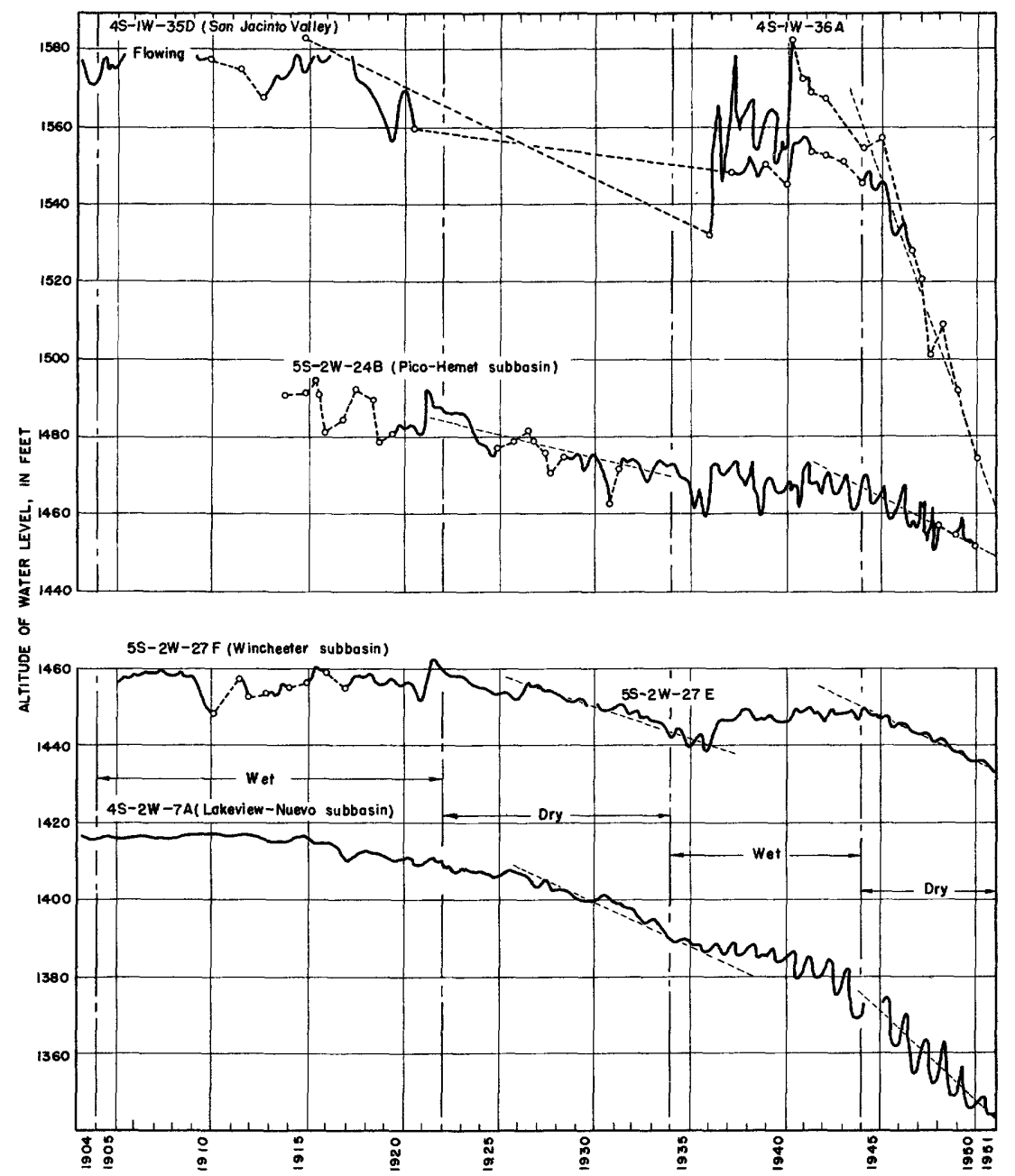

Figure 26. - Altitude of ground water at selected wells in the San Jacinto basin.

become more and more critical unless supplemental waters are obtained from outside the area.

Observations obtained at well at $5 \mathrm{~S}-2 \mathrm{~W}-28 \mathrm{~F}$ and its companion well $5 \mathrm{~S}-2 \mathrm{~W}-27 \mathrm{E}$, also shown on figure 26, are assumed to reflect change in water level in the Winchester subbasin since the winter of 1905 . In many ways this record is like that of the well in the Lakeview - Nuevo subbasin to the north. The water level remained fairly constant from 1905-21 and then reached a maximum in the spring of 1922. Since then the water level has almost continuously declined. The wet period of $1934-44$ produced a minor 
change in trend, but the recovery was not sufficient to modify greatly the overall picture. The decline of 1.6 feet per year during the 1922-34 drought increased to 2.4 feet per year during the drought of 1944-51. This record also indicates an area in which the ground-water reserve appears to be overdeveloped and a condition of overdraft now exists.

Water-level records have been obtained at wells $4 \mathrm{~S}-1 \mathrm{~W}-35 \mathrm{D}$ and $4 \mathrm{~S}-1 \mathrm{~W}-36 \mathrm{~A}$ near the city of San Jacinto in the San Jacinto valley since the spring of 1904 . As shown at the top of figure 26, the water level was sufficiently high in well $4 \mathrm{~S}-1 \mathrm{~W}-35 \mathrm{D}$ for water to flow out of the casing during 1905, 1906-10,1915, 1916, 1917, and 1918. Since these occasions of overflow, the water level in this well has generally declined, with a slight reversal in trend during the 1934-44 wet period. However, the maximum water level during this wet period remained about 20 feet below that of 1918. This difference in water level indicates that an overdraft may now exist. The rate of decline in companion well $4 \mathrm{~S}-1 \mathrm{~W}-36 \mathrm{~A}$ increased to about 13.9 feet per year during the $1944-51$ drought. This is probably the greatest recorded steady rate of decline in the entire San Jacinto basin.

The fourth record on figure 27 was obtained at well $5 \mathrm{~S}-2 \mathrm{~W}-24 \mathrm{~B}$ west of Hemet and shows the ground-water level of the Pico-Hemet subbasin to have declined steadily since the beginning of the record in 1914. A decline of 1.2 feet per year during the 1922-34 drought increased to 2.1 feet per year in the 1944-51 drought.

All of the records on figure 26 tend to indicate that the water reserves of the San Jacinto basin are overdrawn. The greatly accelerated rate of decline in water level during the latest period of drought is probably the result of increased water use.

\section{SAN FERNANDO VALLEY}

The San Fernando Valley is the large alluvial valley in the Los Angeles River basin west of Glendale and Burbank and between the rugged San Gabriel Mountains on the north and the coastal Santa Monica Mountains on the south. Eckis (1934) has estimated the ground-water storage capacity of the valley to be 944,000 acrefeet for a 100 -foot zone extending from 50 feet above to 50 feet below the January 1933 water level.

The observations obtained at four representative wells in the valley are shown on figure 27 and their locations on figure 19. The periods of observation at these wells are considerably shorter than those obtained in the preceding valleys, and this is a distinct handicap in the analysis of these data. 


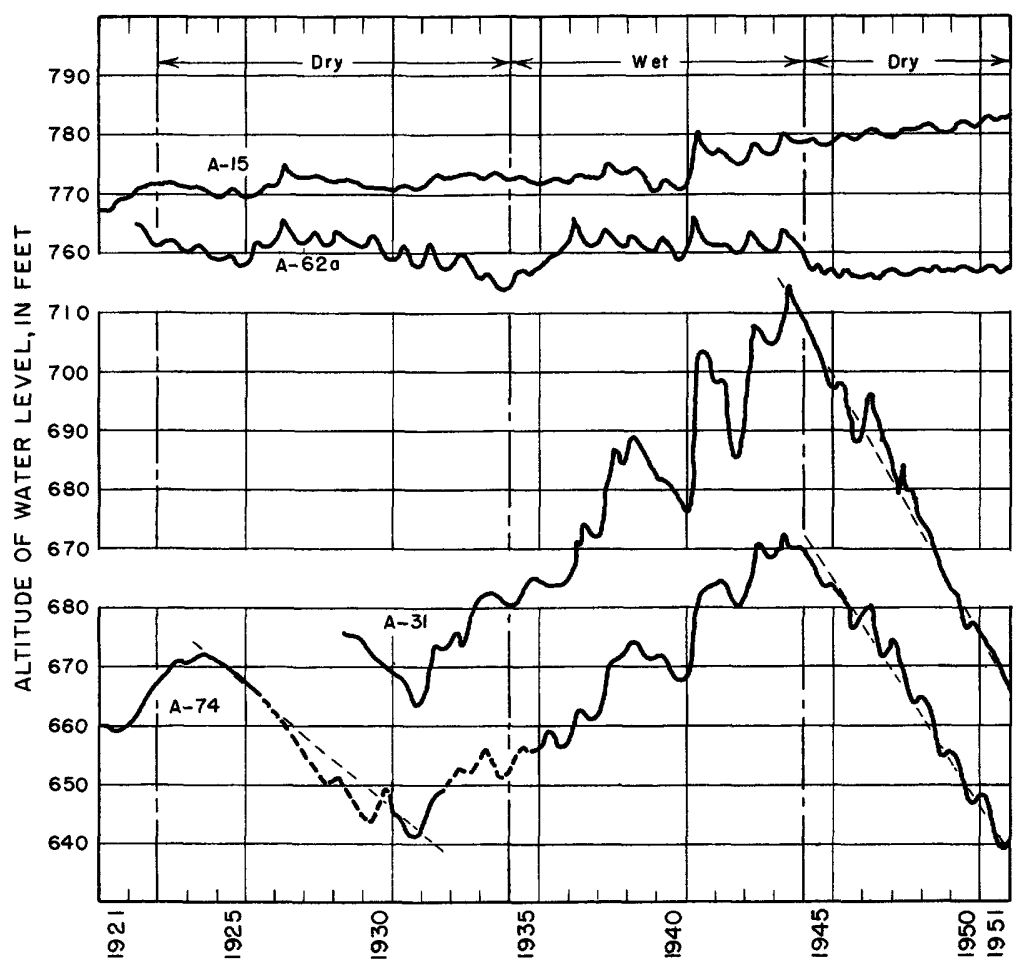

Figure 27. - Altitude of ground water at selected wells in the San Fernando Valley.

A glance at figure 27 shows that the behavior of the water levels in the San Fernando Valley is unlike that for the other areas in the Los Angeles region. This is due largely to the fact that the major part of the San Fernando Valley is within the Los Angeles city limits, and as a consequence, the water requirements of this once-desert valley are satisfied from waters imported from the Owens Valley.

It is believed that the observations obtained at well A-74 in the south-central part of the valley near Van Nuys reflect a trend which is prevalent throughout the eastern sections of the valley. Because of the ready availability of imported waters, less effort is made to utilize the valley's water reserves. Consequently, the return waters from irrigation, together with the natural recharge from precipitation, have exceeded the extractions to such an extent that the ground-water reserves appear to be increasing. In fact, there is every reason to believe that the high water of 1944 may have been the maximum known. In the wet period of 1934-44 the water level in this well rose 52 feet to a point about 20 feet higher than the preceding maximum occurring during the winter 
of 1924. Then, because of the drought of 1944-51 and the accelerated pumping in the lower reaches of the valley, these water levels declined to an altitude about equivalent to that of 1931 .

The observational data obtained at well A-31 southwest of Pacoima largely confirms the record obtained near Van Nuys. An observation made at this well in 1914, shortly after it had been drilled, indicates that the water level has risen about 55 feet to a maximum in the summer of 1944. In the 1944-51 drought that followed, the water level declined 70 feet.

The water level in well A-15, in the western part of the San Fernando Valley at Northridge near the old town of Zelzah, has constantly risen since the beginning of the record in 1920. Even during the 1944-51 drought, the water level rose about 5 feet. This trend in water level is creating a potential drainage problem throughout many parts of the valley.

The observations obtained at well A-62a near Canoga Park in the extreme western end of the valley show almost no change in water level.

It is evident from these records that the ground-water reserves of the San Fernando Valley have not been seriously depleted by the drought of 1944-51.

COASTAL PLAIN

The broad flat areas extending along the coast from Newport Beach on the southeast to Santa Monica on the northwest have been designated for convenience in this report the "Coastal Plain." These broad areas extend inland to the base of the Santa Monica Mountains, the Puente and San Jose Hills, and many other lesser foothill areas. The three major streams of this area meander across these plains before discharging into the ocean. Eckis (1934) has indicated that parts of the area have more than 1,000 feet of marine sediments and alluvial deposits. He further estimated the ground-water storage capacity to amount to about $2,160,000$ acrefeet for a 100 -foot zone extending from 50 feet above to 50 feet below the January 1933 water levels.

The agricultural lands of the Coastal Plain have slowly given way to the more recent urban and suburban developments. At the present time this Coastal Plain contains the most densely populated and industrialized sections of the Los Angeles region. These include the major part of the city of Los Angeles, together with the cities of Long Beach, Beverly Hills, Santa Monica, Huntington 
Park, South Gate, Santa Ana, and many other cities and towns, This change in land use has so greatly increased the water requirements that the local water reserves must be substantially augmented by Owens Valley and Colorado River waters. Even with these supplemental imported waters, the ground-water reserves have been so depleted that sea-water encroachment from the ocean now exists along sections of the coastline.

The history of the water-level behavior in three typical parts of the Coastal Plain is shown on figure 28. The longest of these

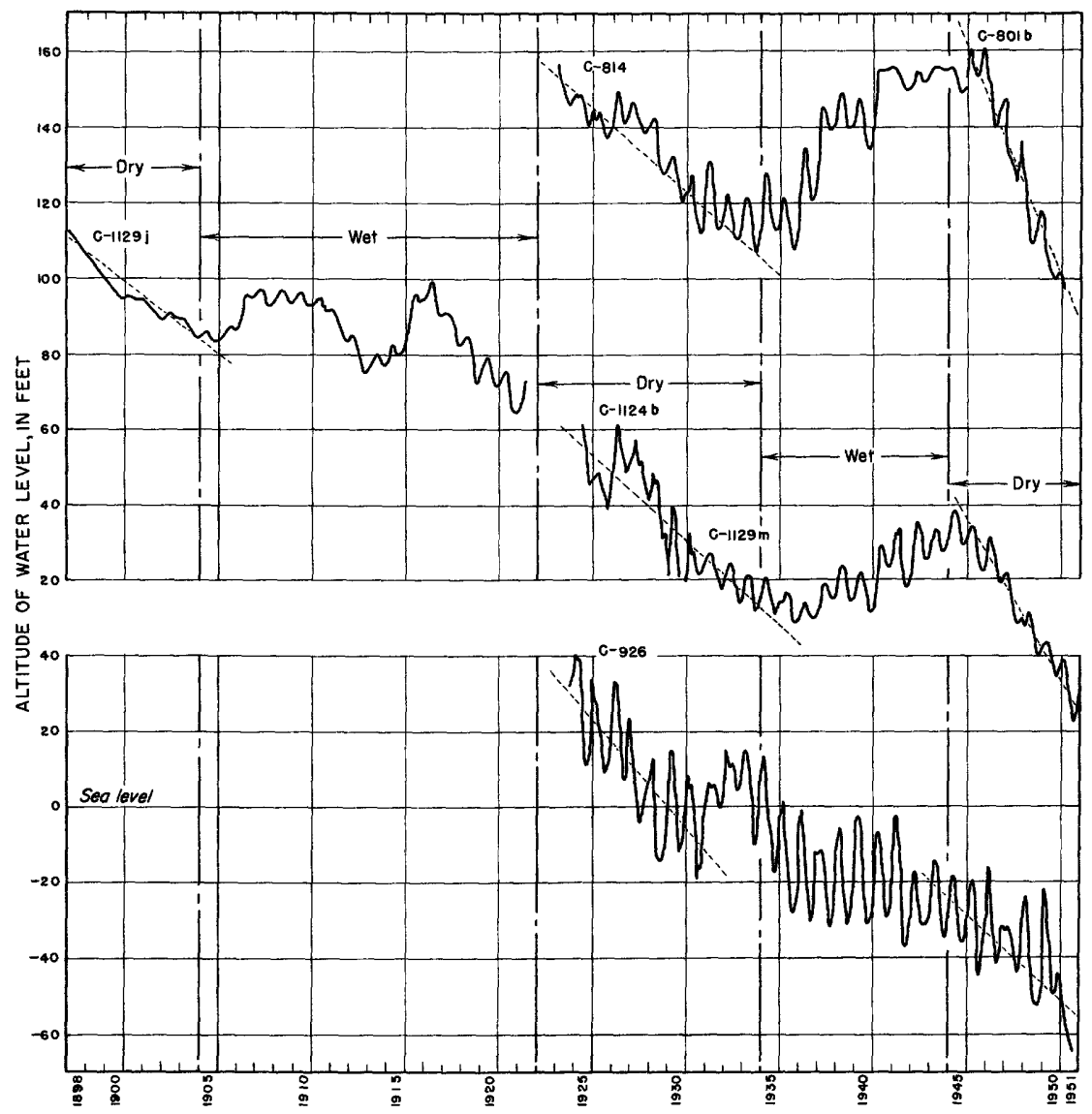

Figure 28. - Altitude of ground water at selected wells on the Coastal Plain.

records is the one obtained at the J. B. Neff well $(\mathrm{C}-1129 \mathrm{j})$ near Anaheim, which is also shown on figure 19. It has been possible to obtain a continuous record of water level at this site since 1898 
by use of the records obtained at companion wells $\mathrm{C}-1124 \mathrm{~b}$ and $\mathrm{C}-1129 \mathrm{~m}$. This 53 -year period includes the three most recent droughts.

Between the spring of 1898 and the fall of 1905 the water level in this well dropped 29 feet. During the concluding phase of the 1893-1904 drought, the water levels declined at a rate of 3.8 feet per year, as indicated on figure 28. As a result of this serious depletion in the ground-water reserves, Walter C. Mendenhall $(1905 \mathrm{a}-\mathrm{c})$ was requested to prepare a report on the ground-water supply of the Coastal Plain.

After the end of the drought in 1904 and the increasing groundwater recharge of the wet years that followed, the water levels recovered in the spring of 1917 to within 13 feet of the 1898 level. These water levels, however, were not long sustained, because the increasing water use and a deficient precipitation brought a new and continuous decline of 90 feet between the spring of 1917 and the fall of 1936 . During this period the average rate of decline had increased to 4.5 feet per year.

The precipitation of the wet years that ended this drought brought a recovery of about 30 feet in the water levels by the spring of 1945. Then the third drought of 1944-51 caused a reversal in trend and a rapid decline in the water levels to about 18 feet below sea level in the summer of 1951. This low point was 134 feet below the first record in the spring of 1898. During this latest drought of 1944-51, the rate of decline had increased to 8.4 feet per year.

The top diagram on figure 28 gives the water levels at well C-814 and its companion well C-801b along the Rio Hondo and San Gabriel River in the Montebello and Whittier recharge areas of the Coastal Plain. Under the influence of the 1922-34 drought the water level in well C-814 declined about 50 feet by the fall of 1936 . The average decline during this period was 4.4 feet per year.

Upon the conclusion of the drought there was complete recovery of the water level by the spring of 1942 . The observations obtained at the companion well $\mathrm{C}-801 \mathrm{~b}$ indicate that after recovery a second period of depletion occurred because of the 1944-51 drought, and the average rate of decline increased to 11.8 feet per year.

These two relatively short records show that there was nopermanent depletion in this recharge area.

The bottom record shown on figure 28 shows the water-level in well C-926 just north of the cities of Signal Hill and Long Beach. 
This well is in the area designated as a pressure area in which the water-bearing aquifers are confined between beds of relatively impermeable material. The changes in water level represent changes in pressure head and do not necessarily represent the unwatering of the water-bearing alluvium. This observational record shows that the water levels have declined almost continuously since the spring of 1925. By the summer of 1951 the water level in this well had declined to almost 70 feet below sea level. Below-sea-level altitudes of this amount close to the coast seriously threaten the entire ground-water reserves with sea-water encroachment. Consequently, considerable effort is now being made to reduce the extractions from this storage.

By 1951 basin-wide water levels in the Coastal Plain were the lowest known. The steadily increasing rates of decline during periods of deficient precipitation, and the lack of recovery during substantial wet periods clearly indicate that the ground-water reserves of the Coastal Plain have been overdrawn.

\section{VENTURA REGION}

The Ventura region consists of the Calleguas Creek, Santa Clara River, and Ventura River basins. This 2,250-square-mile region, which includes most of Ventura County and parts of Los Angeles County, is shown on figure 29.

Isohyetal maps prepared for the region by the California Division of Water Resources (1933) indicate that the mean annual precipitation ranges from about 30 inches in the headwater areas of Sespe Creek to about 9 inches in the desert headwaters of the Santa Clara River. This regional precipitation produces a mean annual natural (unaltered by diversions or storage) runoff of about 300,000 acrefeet (State Water Resources Board, 1951), or 2. 5 inches over the area. Because of the lack of surface reservoirs, due primarily to unfavorable topographic conditions, about one-half of this runoff wastes into the ocean.

Practically all of the region's urban and agricultural areas are in the valley floor areas, which constitute about 16 percent of this rugged mountainous region. These areas produced agricultural crops valued at $\$ 66,000,000$ in 1951 (Los Angeles County Board of Supervisors, 1952). The principal crops of the region are citrus, dry beans, walnuts, cattle, and dairy products.

The regional population trend is similar to that shown in table 7 for the entire southern California area. A Ventura County population of 14,000 in 1900 increased 8 -fold in 50 years to 115,000 in 1950. The urban development is largely concentrated around the cities of Oxnard, Ventura (San Buenaventura), and Santa Paula. 


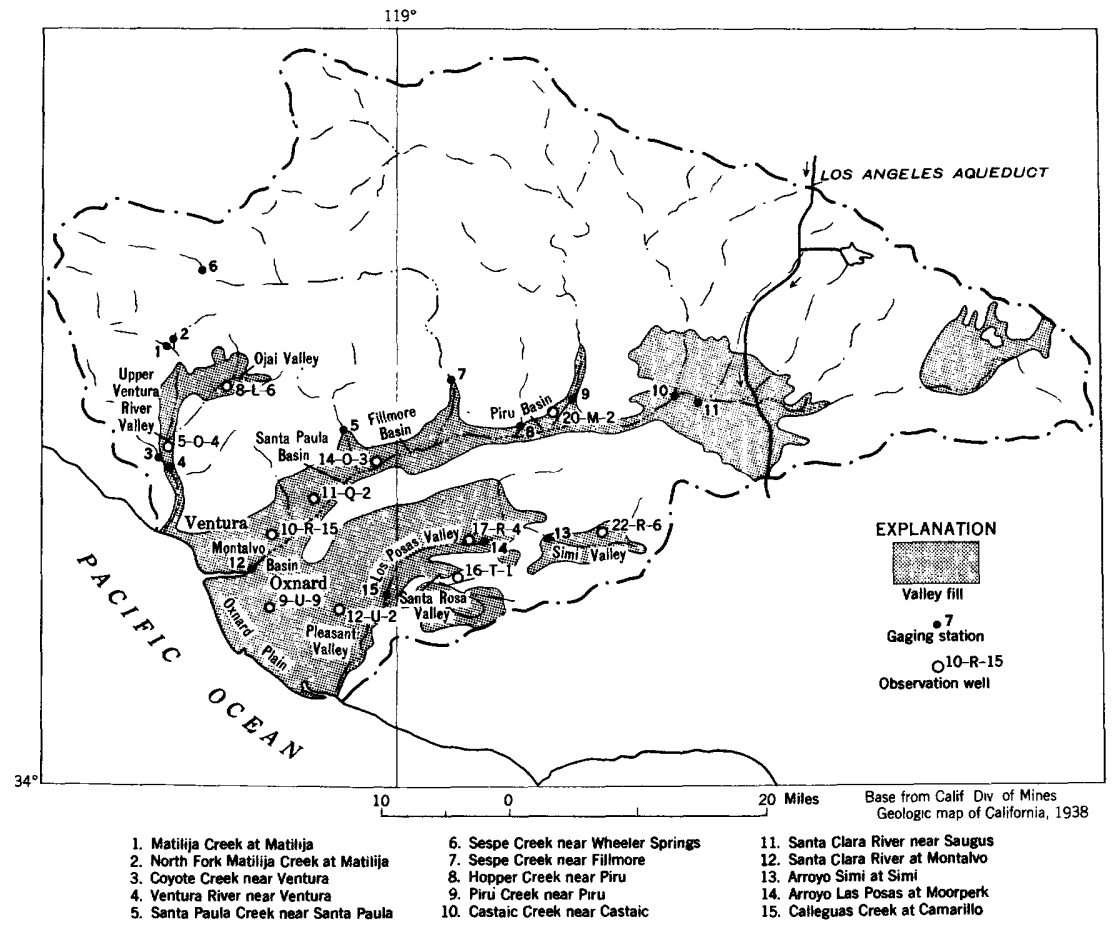

Figure 29. - Map of the Ventura region showing valley fill, observation wells, and gaging stations.

\section{WATER REQUIREMENTS}

After the founding of the mission at San Buenaventura in 1782, the early settlers generally confined their agricultural activities to the raising of cattle and sheep. It was not until the early land booms of 1880 that intensive agriculture became established in the Ventura region and a great increase in water requirements developed. These ever-increasing water requirements were satisfied from surface and ground-water reserves by a number of mutual, municipal, or private service units. Among the larger of these was the municipal water department of the city of Oxnard. The annual deliveries by this municipal service unit since 1915 are shown on figure 30. Before World War II these deliveries increased at a slow but steady rate; however, with the advent of the war there was a rapid acceleration in the water deliveries. The annual water deliveries of 1,350 acre-feet in 1941 increased 217 percent in a $10-$ year period to a delivery of 4,280 acre-feet in 1951. This record of deliveries is believed to be typical of that of most of the urban areas in the region. 


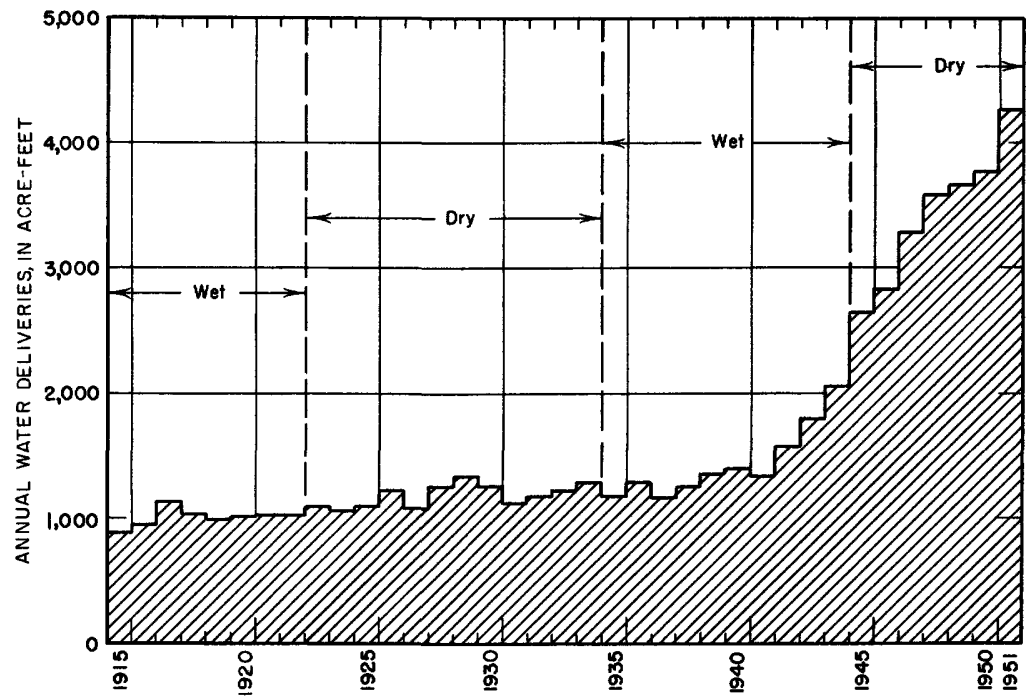

Figure 30. - Annual water deliveries to the city of Oxnard.

However, the principal use of water in the region is for irrigation. The acreage of irrigated lands increased from about 12, 000 in 1900 to more than 120,000 in 1950.

Currently, all of the region's water requirements must be satisfied from local surface-and ground-water reserves. The estimated annual demand made upon these water reserves has steadily increased from about 15,000 acre-feet in 1900 to 140,000 acre-feet in 1950, as indicated on figure 31. Since 1920, these water requirements have increased 2.5 times.

During the drought of 1922-34, the estimated annual water requirements averaged about 75,000 acre-feet. Subsequently, the water requirements increased by 80 percent to an average of 130,000 acre-feet during the 1944-51 drought.

\section{WATER RESERVES}

As already indicated, the only source of water currently available in the Ventura region is from the precipitation that occurs within the area. After first satisfying the soil moisture deficiencies in the root zone of the plant cover, precipitation forms the runoff in the stream channels and the recharge to the groundwater reserves.

Evidence of the extreme variability in the annual runof is shown by the record of Sespe Creek, one of the region's principal 


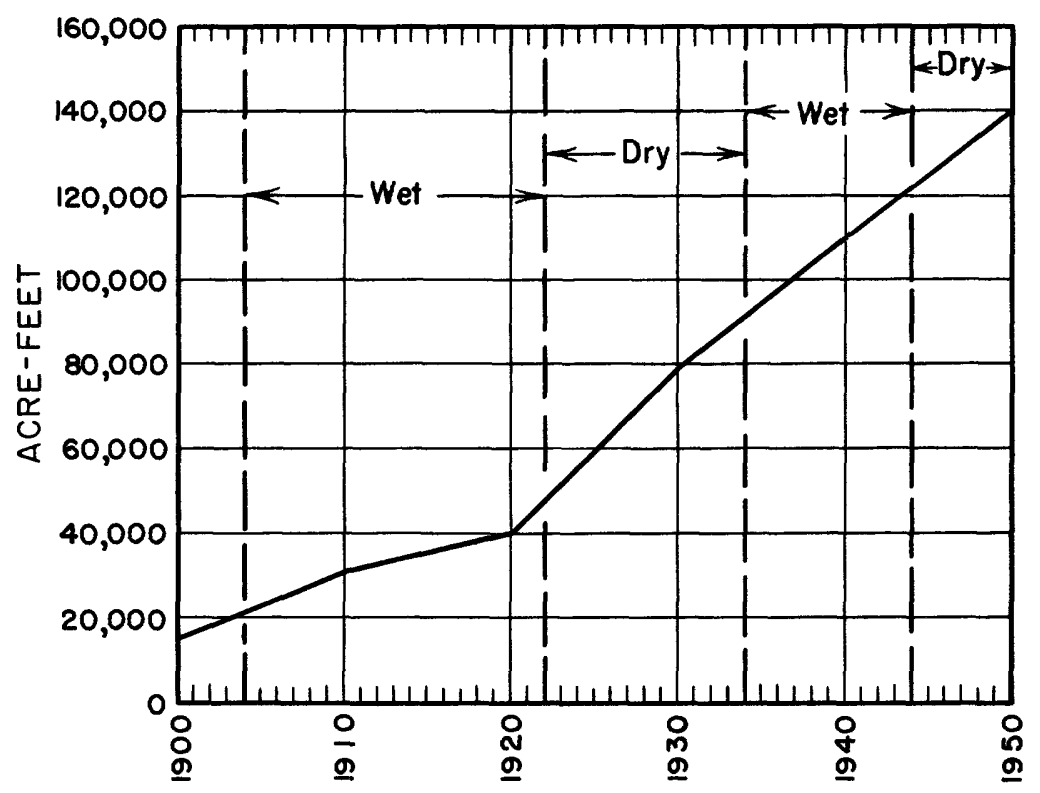

Figure 31. - Estimated annual water requirements of the Ventura region.

streams (upper part of fig. 32). The location of this gaging station (site 7) is shown on figure 29. Within the 31-year period of record, the annual runoff has ranged from 3,500 acre-feet in 1951 to 376,000 acre-feet in 1941, and the 5 wettest years contained 54 percent of the total runoff.

Because of the extreme uncertainity of the amount and sequence of the surface runoff, most of the region's water requirements have been obtained from the more stable ground-water reserves. These ground-water reserves are generally found in the narrow alluvial valleys along most of the water courses (fig. 29) and are largely sustained by the runoff in the stream channels.

The potential source of recharge to both the surface- and groundwater reserves is the flood runoff now being wasted into the ocean. This mean annual wastage has been estimated to be of the order of 160,000 acre-feet, which is somewhat greater than the current estimated annual water requirements shown on figure 31 .

\section{EFFECT OF DROUGHT OF 1944-51}

\section{UPPER VENTURA RIVER VALLEY, FILLMORE AND SANTA PAULA baSinS}

Because of considerable similarity in water-level fluctuations, these three alluvial river valley basins are discussed together. 


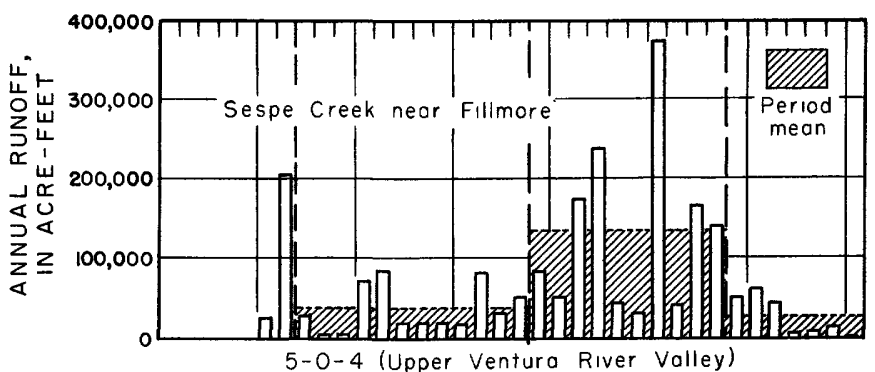

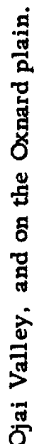
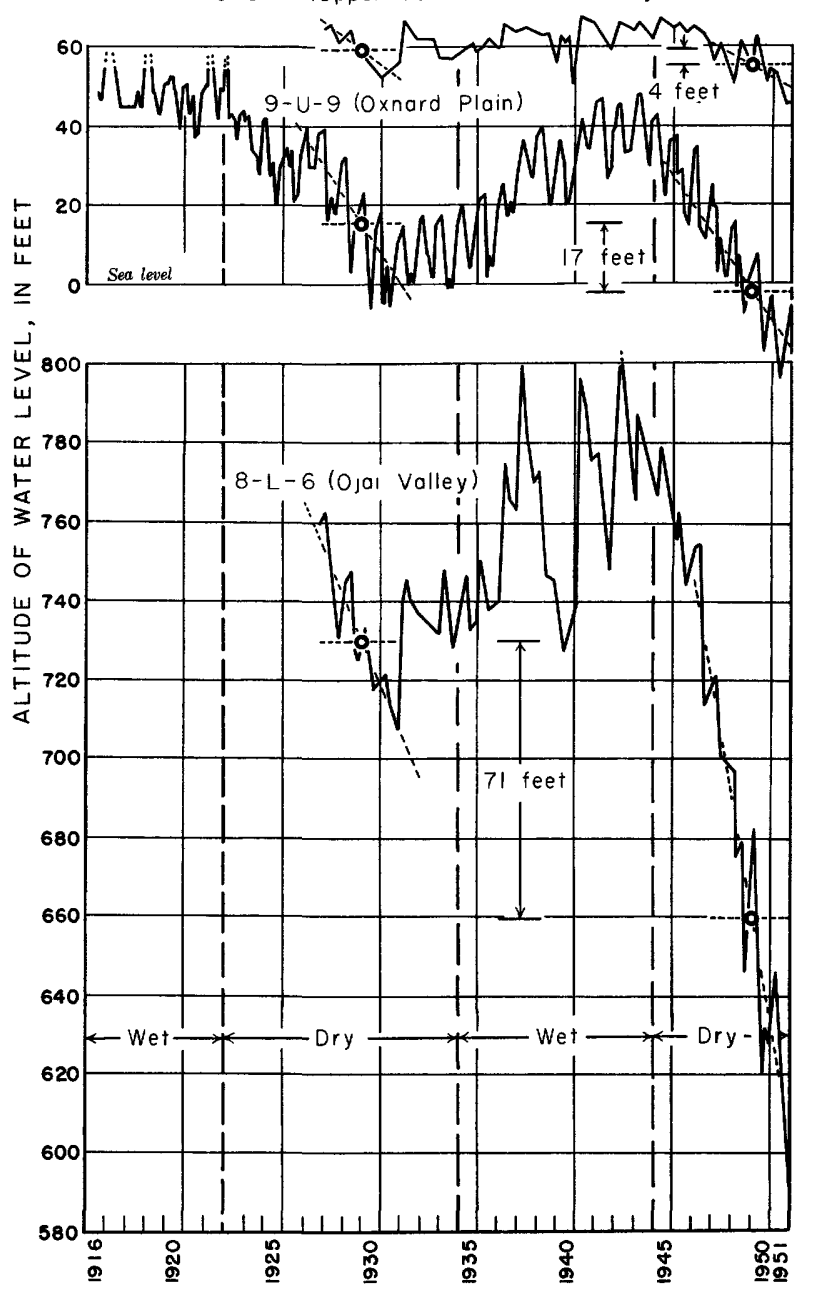

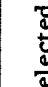

\&

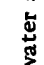


As shown on figure 29, the upper Ventura River valley is a very narrow valley along the Ventura River from the confluence of Matilija (head of Ventura River) and North Fork Matilija Creeks to Coyote Creek. The Fillmore basin is also a narrow river valley along the Santa Clara River between the towns of Santa Paula and Fillmore. The Santa Paula basin is a similar valley along the channel of the Santa Clara River just downstream from the Fillmore basin.

The water-level records obtained at well 5-0-4, located in the lower reaches of the upper Ventura River valley are assumed to reflectbasin-wide changes in storage. (These and subsequent records of water levels in the Ventura region are based on a systematic observational program started in 1927 by the California Division of Water Resources and continued since 1932 by the Ventura County Water Survey.) The ground-water reserves in the upper Ventura River valley are sustained largely by the recharge from the storm runoff originating in the higher mountain areas. The records shown on figure 32 indicate that an intermittent recharge, even during moderately dry years, is often sufficiently large to restore all the depletions made during the preceding dry period.

This record suggests, insofar as it reflects basin-wide conditions, that the ground-water storage in the basin has not been seriously depleted by the drought of 1944-51. The average altitude of the water level in this key well during the last four years of this drought period, indicated by the circle on fig. 32, was only about 15 feet below the maximum of the record and only 4 feet below the average altitude for a similar 4-year period in the preceding drought of $1922-34$.

In the Fillmore basin, the water-level fluctuations observed at well 14-0-3 are assumed to be typical of the entire basin. The record obtained at this key well, although not given on figure 32 , has the same general characteristics found in the preceding basin. The intermittent recharge to the basin's ground-water reserves from storm runoff is generally sufficiently great to maintain the optimum water levels, except during unusually dry periods.

The drought of 1944-51 appears to have had minor effect on the water level of this basin. Even though the water levels in the summer of 1951 were the lowest in the period of record, they were only about 18 feet below the maximum altitude just before the drought. The average water level during the 4-year period of 1948-51 in the current drought was only 6 feet below a similar 4-year dry period 20 years earlier.

The record of water-level fluctuations obtained at well 11-Q-2 (not shown) near the middle of the Santa Paula basin is also as sumed to represent basin-wide conditions. It differs only slightly from that shown for the upper Ventura River valley. During the 
summer of 1951 the water levels were the lowest during the period of record, but only 24 feet below the maximum altitude. The average altitude of the water level for the 4 driest years of the drought of 1944-51 was only 3 feet below those of 1928-31.

\section{PIRU BASIN}

That part of the Santa Clara River's alluvial valley upstream of the Fillmore basin and below the Los Angeles County line is known as the Piru basin. The record of water-level fluctuations obtained since 1926 at well 20-M-2, near the town of Piru, is assumed to reflect basin-wide ground-water conditions. Although not included on figure 32, the distribution pattern is similar to the records given for the Oxnard plain and Ojai Valley.

Unlike the preceding basins, the recharge during a single year or even during a small group of moderately wet years is not sufficiently great to restore the ground-water depletions resulting from extended dry periods. Consequently, water levels have fluctuated through a wide range during the relatively short period of record.

By 1951 the water level was the lowest in the entire period of record. Between the spring of 1944 and the winter of 1951, the water level declined 152 feet. The maximum average annual rate of decline during this period amounted to 22.2 feet per year in the final 4-year period of the 1944-51 drought. Such a rate of decline was 1.8 times greater than that for the equally dry 4 -year period of 1928-31. As elsewhere in southern California, these increasing rates of decline in ground-water reserves reflect the increase in the local water requirements. As a result of these greater requirements, the average water level of the 4-year dry period of 1948-51 was 16 feet below that for the comparable 4-year dry period 20 years earlier.

\section{OXNARD PLAIN}

The flood plain of the coastal streams of Calleguas Creek and of the Santa Clara River, which extends about 18 miles along the coast, is known as the Oxnard plain. Because of favorable climatic environment, the Oxnard plain has become the region's principal urban, as well as agricultural area.

The water resources of the Oxnard plain are confined to the ground-water reserves that underlie most of the area. One of the longest available records showing the changes in these reserves is that obtained at well 9-U-9 near Oxnard and shown on figure 32 . In the vicinity of this well, the water reserves were so great in 
the winters of $1916-17,1918-19,1921-22$, and 1922-23 that water flowed out of the casing above ground surface.

In the spring of 1944 at the end of the 1934-44 wet period, water level was about 7 feet below ground surface. Then during the drought of 1944-51 the water level declined 72 feet to an altitude of 24 feet below sea level in the summer of 1951 .

The decline during the last 4 years of the 1944-51 drought averaged 7.5 feet per year, which was practically identical with the rate of decline for a similar 4 -year dry period 20 years earlier. However, as shown on figure 32 , the average water level declined 17 feet between these dry periods. This decline in water level is believed to indicate a condition of overdraft.

Because the water-bearing deposits along the coast are believed to be in contact with the salt water of the ocean,contamination of the potable ground-water supplies is seriously threatened whenever water levels are below sea level. Consequently, as a result of this continuous overdraft, Banks (1952) has included the Oxnard plain among those coastal areas threatened by sea-water encroachment.

\section{PLEasant valLey}

East of the Oxnard plain, as shown on figure 29, lies Pleasant Valley. Water conditions within this valley are very similar to those in the Oxnard plain area. The record of water-level fluctuation obtained at well $12-U-2$, about $3 \frac{1}{2}$ miles southwest of Camarillo, is assumed to reflect the changes in ground-water reserves throughout the valley. In the winter of 1927 , the water reserves were so great that water flowed out of the casing of this well above ground surface. Since that date the water levels have declined 92 feet to a minimum of 53 feet below sea level in the summer of 1951 .

During the last 4 years of the 1944-51 drought the water level was 40 feet below a similar 4-year dry period occurring 20 years earlier. Thus, there is every reason to believe that an overdraft of the ground-water reserves exists.

\section{MONTALVO BASIN}

The Montalvo basin lies north of the coastal plain along both sides of the Santa Clara River at the upstream edge of the Oxnard plain. The records of water levels obtained at well 10-R-15 about a mile southeast of Saticoy are assumed to reflect basin-wide 
changes in the ground-water reserves. The variations in water level at this well are also very similar to the Oxnard plain well shown on figure 32 .

Between spring of 1944 and the summer of 1951 the water level declined 96 feet to about 10 feet above sea level. The average annual water level in 1951 at the end of the 1944-51 drought was 20 feet below similar minimum levels in the 1922-34 drought.

\section{OJAI VALLEY}

Ojai Valley is a small picturesque upland valley along San Antonio Creek just south of the Santa Ynez Mountains and west of Sulphur Mountain. Because of favorable climatic conditions this valley has become a very desirable residential and agricultural area. Changes in the valley's ground-water reserves are believed to be reflected in the record obtained at well $8-\mathrm{L}-6$, about $1 \frac{1}{2}$ miles east of Ojai, and plotted on figure 32 . These reserves were sufficiently great enough in the springs of 1938 and 1943 for water to flow from the casing above ground surface. Then, because of lack of recharge during the 1944-51 drought, the extractions caused the water level in this well to decline 212 feet by the winter of 1951.

As indicated on figure 32, the average rate of decline of 28 feet per year for the dry 4-year period of 1948-51 is considerably steeper than for the preceding similar 4-year dry period of 192831. This increasing rate of decline merely reflects the increase in water requirements since 1928-31. The average decline between these two 4-year dry periods amounts to 71 feet, as shown on figure 32, and suggests that the valley's water reserves are overdrawn.

\section{SIMI VALLEY}

Simi valley is in the upper part of the Arroyo Las Posas drainage area, a tributary to Calleguas Creek. This valley contains about 12, 000 acres of agricultural lands of which about two-thirds is irrigated. The principal crops are citrus and other fruits, and walnuts. The social and commercial activities are centered around the towns of Simi and Santa Susana.

The valley's water reserves are confined to the ground-water storage, which is largely recharged and sustained by the deep penetration of a very meager annual precipitation on the valley floor and the runoff from the surrounding foothills and mountains. 
The annual runoff of the Arroyo Las Posas near Moorpark (at site 14 on figure 29) is shown on the upper part of figure 33 as representative of the magnitude and irregularity of this runoff.

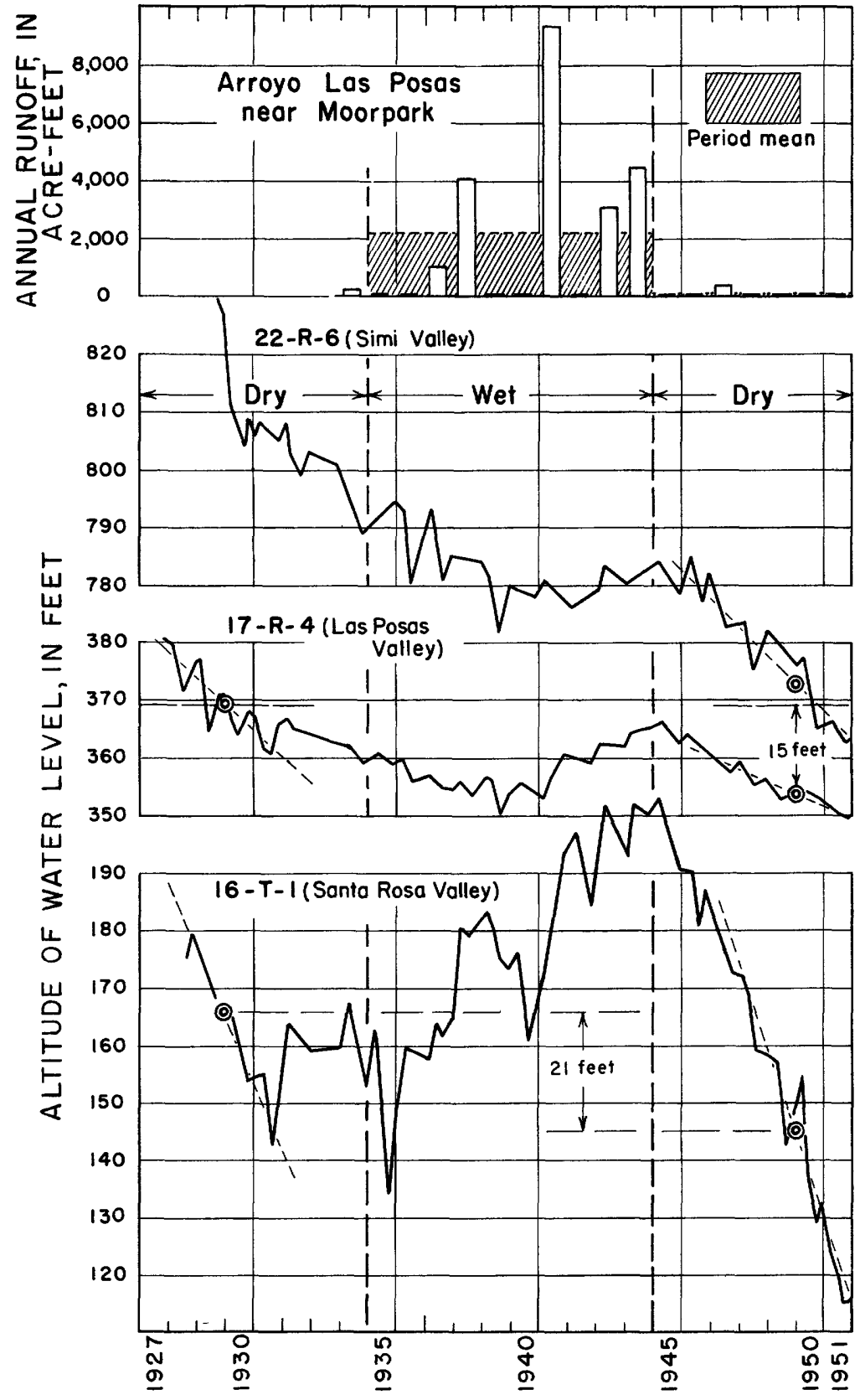

Figure 33. - Annual runoff of Arroyo Las Posas and altitude of ground water at selected wells in the Simi, Las Posas, and Santa Rosa valleys. 
An average annual runoff from this 114-square-mile drainage area of 2,200 acre-feet during the 1934-44 wet period declined to 67 acre-feet during the 1944-51 drought.

The water-level records obtained at well 22-R-6, about threequarters of a mile west-northwest of Santa Susana, have been included on figure 33 as reflecting changes in ground-water reserves. This record shows that the ground-water extractions to satisfy the local water requirements have greatly exceeded the replenishment. As a result the water level declined 76 feet between the winters of 1929 and 1951. There was only slight recovery of water level during the 10-year wet period of 1934-44. This clearly indicates a condition of overdraft, in which the ground-water reserves are being mined with little possibility of replenishment.

\section{LAS POSAS VALLey}

The Las Posas valley is a long narrow alluvial valley along the Arroyo Las Posas, downstream from the Simi valley, containing about 14,000 acres of agricultural lands. The residential and commercial activities are centered around the towns of Somis and Moorpark.

The water resources of the valley are confined to the groundwater reserves. Changes in these reserves are believed to be reflected in the water-level record obtained at well 17-R-4 (fig. 33), about 1 mile west of Moorpark. The general decline in water level since 1927, with little recharge during wet periods, indicates that the water reserves of this valley may also be overdrawn.

\section{SANTA ROSA VALLEY}

The narrow alluvial Santa Rosa valley lies along the Arroyo Santa Rosa and Arroyo Conejo, which are tributary to Calleguas Creek, and contains about 9,000 acres of agricultural lands. The valley's water resources are confined to the ground-water reserves. Changes in these reserves are reflected by the waterlevel record obtained at well 16-T-1. As shown on figure 33, the water level appears to have responded fairly rapidly to the recharge from the wet years between 1934-44. During this 10-year wet period the recharge to ground-water reserves caused a recovery in water level of more than 50 feet.

Then under the influence of the 1944-51 drought, the water levels declined almost 90 feet to a new minimum in the winter of 1951. The net decline in the average annual water level for the 
two comparable 4-year dry periods in this and the previous drought was to 21 feet. Such a decline is probably an indication of an overdraft of the water reserves.

\section{SANTA BARBARA REGION}

The most northernly area included in this report is the Santa Barbara region shown on figure 34 . It includes most of Santa

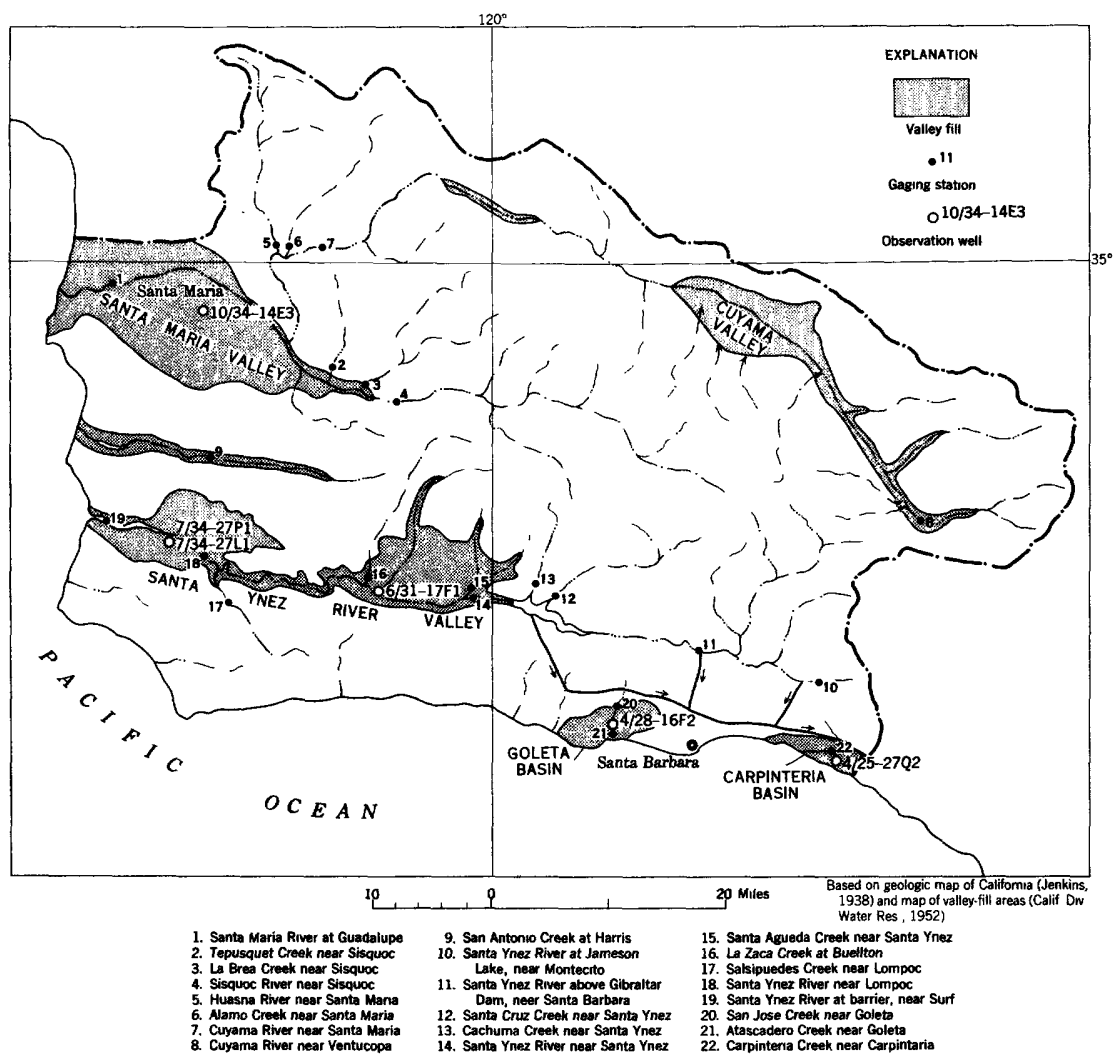

Figure 34. -Map of the Santa Barbara region showing valley fill, key observation wells, and gaging stations.

Barbara County and that part of the Santa Maria River basin in San Luis Obispo County. The region has an area of 3,360 square miles, of which 2,820 square miles have been classified as mountain and foothill areas. 
In the California Conservation Commission's report of 1912 the potential agricultural lands of this region were estimated to be slightly less than 300,000 acres; in 1950 more than 60,000 were irrigated. The value of the agricultural crops grown in 1951 was $\$ 62,000,000$ (Los Angeles County Board of Supervisors, 1952) and consisted mainly of cattle, lemons, lettuce, dairy products, and dry beans.

As shown in table 7, the population of Santa Barbara County has increased from 1,185 in 1850 to 98,220 in 1950. About 50 percent of this population is concentrated in the south coast communities of Santa Barbara and Montecito where water supply has been a critical problem since the Spaniards settled the area in 1782 .

\section{WATER REQUIREMENTS}

The two principal service units of the region are the water departments of the cities of Santa Barbara and Santa Maria. The anannual water deliveries made by these service units are shown on figure 35. The annual deliveries to the city of Santa Barbara,

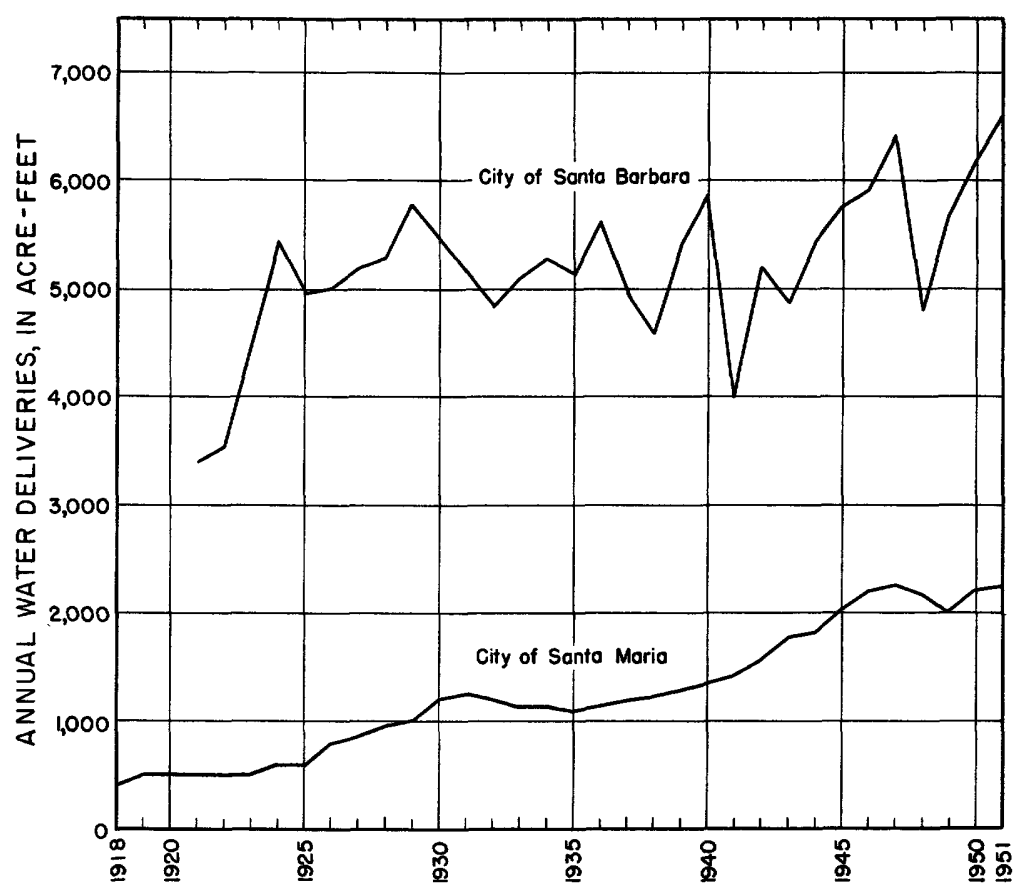

Figure 35. - Annual water deliveries to the cities of Santa Barbara and Santa Maria. 
while containing a certain amount of variability, have tended to increase steadily from 3,400 acre-feet in 1921 to 6,600 acre-feet in 1951. The annual deliveries to the city of Santa Maria have also steadily increased from 500 acre-feet in 1921 to 2,200 acrefeet in 1951. This increase of 340 percent is believed to be typical of the increase in domestic water requirements of the urban areas of the region.

The annual agricultural water requirements, previously defined as that part of the evapotranspiration losses of the agricultural crops supplied by supplemental irrigation water, have also shown a tremendous increase. The irrigated acreage of only 3,200 acres in 1900 has increased to 60,400 acres in 1950 .

The estimated regional annual total water requirements, representing the sum of the agricultural, domestic, and industrial water needs, are shown on figure 36 for the period of 1900 to 1950 .

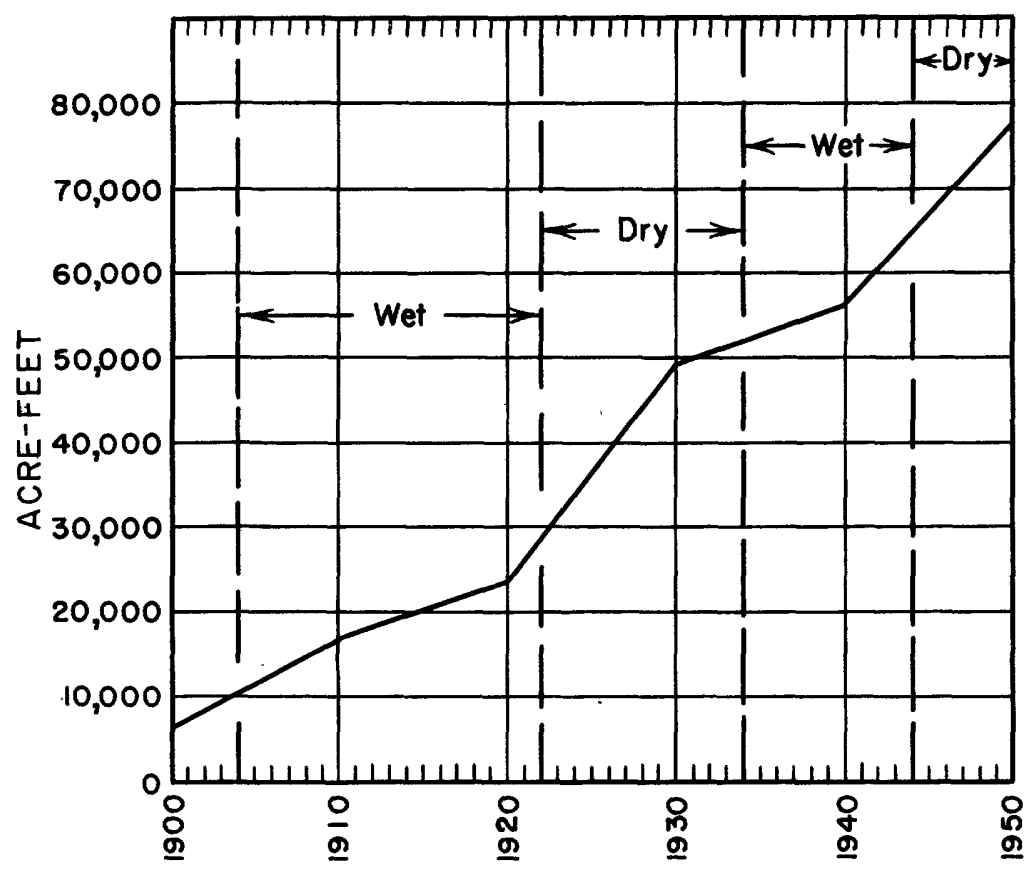

Figure 36. - Estimated annual water requirements of the Santa Barbara region.

On the basis of per capita urban water consumption, the supplemental irrigation requirements, and census data, it has been possible to estimate the regional water requirements for this 
50-year period. This estimate (fig. 36) indicates a fairly steady increase from 6,200 acre-feet in 1900 to 78,000 acre-feet in 1950, and an average rate of increase of 1,400 acre-feet per year.

\section{WATER RESERVES}

Like many other parts of southern California, the entire water supply of the Santa Barbara region is dependent upon the precipitation falling within it. It has not been practicable to import water from areas of water surplus. The State Water Resources Board (1951) has estimated the regional average annual natural runoff from the mountain and foothill areas to be about 330,000 acrefeet. After recharging the ground-water reserves in the alluvial valleys, an average annual runoff of about 185,000 acre-feet wastes into the ocean. This wastage is a measure of the water available for salvage within the region.

However, the runoff from the region's mountain and foothill areas has not proven to be a very dependable source unless sizable surface reservoirs are available for storing the flood runoff. For example, runoff data on the Santa Ynez River near Santa Ynez indicate that 50 percent of the runoff occurs in 1 percent of the time, or 3,6 days per year, and that 90 percent of the runoff occurs in 10 percent of the time, or 36 days per year. In order to make this runoff available for use, tremendous storage facilities would be required and it is extremely doubtful that a sufficient number of economical storage sites actually exist.

Because dependable streamflow is not available and surface storage facilities are inadequate at present, nearly all the water used within the region is derived from ground-water reserves. Replenishment of these subsurface reserves is generally dependent upon the flood runoff during the wetter years and excessive precipitation on the valley floor.

\section{EFFECT OF DROUGHT OF 1944-51}

\section{SANTA MARIA VALLEY}

As shown on figure 34, the Santa Maria Valley is in the northwest corner of the region. The records of change in water level obtained at key well 10/34-14E3, and shown on figure 37, are assumed to reflect valley-wide ground-water conditions. This 34year record clearly indicated that during dry periods, replenishment of the ground-water reserves was not sufficient to meet the requirements of the valley. In fact, the water level steadily declined 74 feet between 1918 and 1936, indicating that all the 


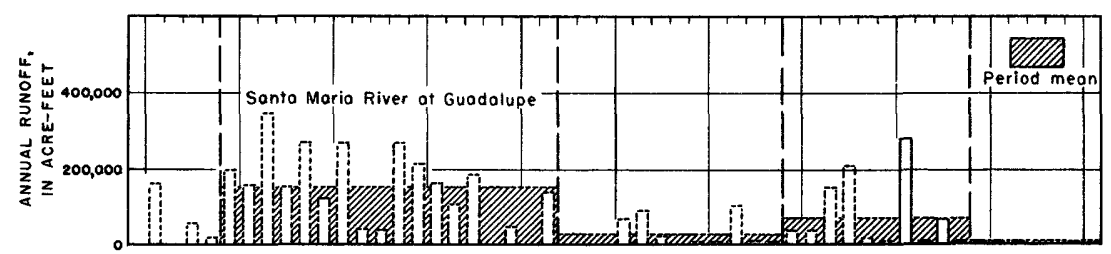

10/34-14 E 3(Sonta Maria Valley)

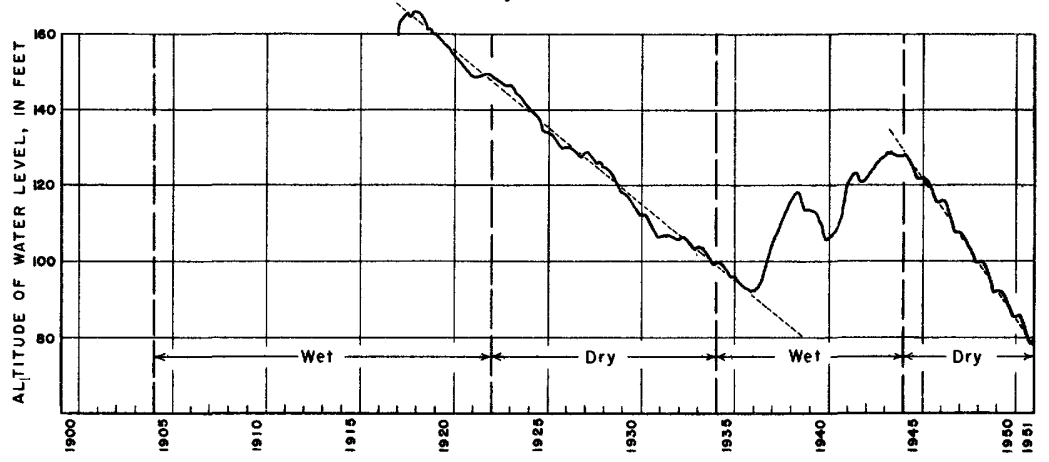

Figure 37. - Annual runoff of the Santa Maria River and altitude of ground water at observation well in the Santa Maria valley.

recharge, as well as this storage, was used to satisfy the water requirements. The record further shows that individual wet years within a dry period, such as 1926, 1927, and 1932, had little or no effect upon the rate of decline of water levels. It took the substantial recharge of a succession of wet years, such as those occurring in the period 1935-44, to change the trend. However, 'despite the substantial recharge during this wet period, the net exchange for the 26-year period of 1918-44 was a 37-foot depletion in the ground-water reserve. As a result of this and earlier depletions, the water level during the summer of 1951 was about 87 feet below the maximum of 1918 and probably about 40 feet below the minimum level that had occurred during the drought of 18931904 (Worts, 1951).

The annual runoff of the Santa Maria River at Guadalupe has been included as a part of figure 37 because it is a partial index of the annual recharge to the ground-water reserves. The major part of the runoff shown on this diagram has been estimated by the State Water Resources Board (1951). This record suggests that the recharge to ground-water storage may have been fairly negligible during both drought periods. If so, the increase in rate of decline in water level from 4 feet per year during the first drought to 7 feet per year during the last drought could reflect the increase in water requirements. 
The water-level record at the key well clearly shows that the ground-water reserves are overdrawn. The recharge during the wet period of 1934-44 did not raise the level to its position of 1918; and, in a general way, this failure to replace the depleted storage is a measure of the overdraft of ground-water reserves. If this trend were to continue, it is evident that the water levels during each succeeding wet period will be lower. Consequently, the continuous use of these ground-water reserves at current rates poses a serious threat to the economy of the valley unless means can be found to increase the recharge to ground-water storage or to provide additional water from other sources.

\section{CUYAMA VALLEY}

The Cuyama valley (fig. 34) lies in the upper Cuyama River drainage area. Before 1941 most of the agriculture in the valley was confined to dry farming, grain being the principal crop. Stock raising was also important. After 1941, irrigated areas increased rapidly, and were planted largely in potatoes. Most of the water for these agricultural crops came from the ground-water reserves.

Because of the increased development, water levels dropped about 10 feet in the lower part of the valley and about 60 feet at the upper end of the valley near Ventucopa during the 1944-51 drought. Very little hydrologic data had been obtained in the Cuyama valley before 1941 . Consequently, it is not possible to relate the effects of the $1944-51$ drought to previous droughts.

\section{SANTA YNEZ RIVER VALLEY}

The Santa Ynez River valley is a long narrow alluvial valley extending from the ocean to San Lucas Bridge, below Cachuma Dam, and is shown on figure 34. Records obtained at well 7/34-27P1, and its companion well 7/34-27L1, together with well $6 / 31-17 \mathrm{~F} 1$, are thought to reflect changes in water level within the valley. These records, as well as the annual runoff of the Santa Ynez River at Robinson Bridge near Lompoc, are shown on figure 38 .

Water-level records of the Santa Ynez River valley prior to 1930 are not available; consequently, comparison of the current drought with the drought of 1922-34 has not been possible. The records generally indicate that replenishment each year, even during the drier years, was sufficient to replace withdrawals until about 1944 . In fact, during the period 1932-44 water levels showed a continuous upward trend, indicating that the annual recharge exceeded the annual requirements. Then a noticeabledecline in water levels began with the drought of 1944-51. 

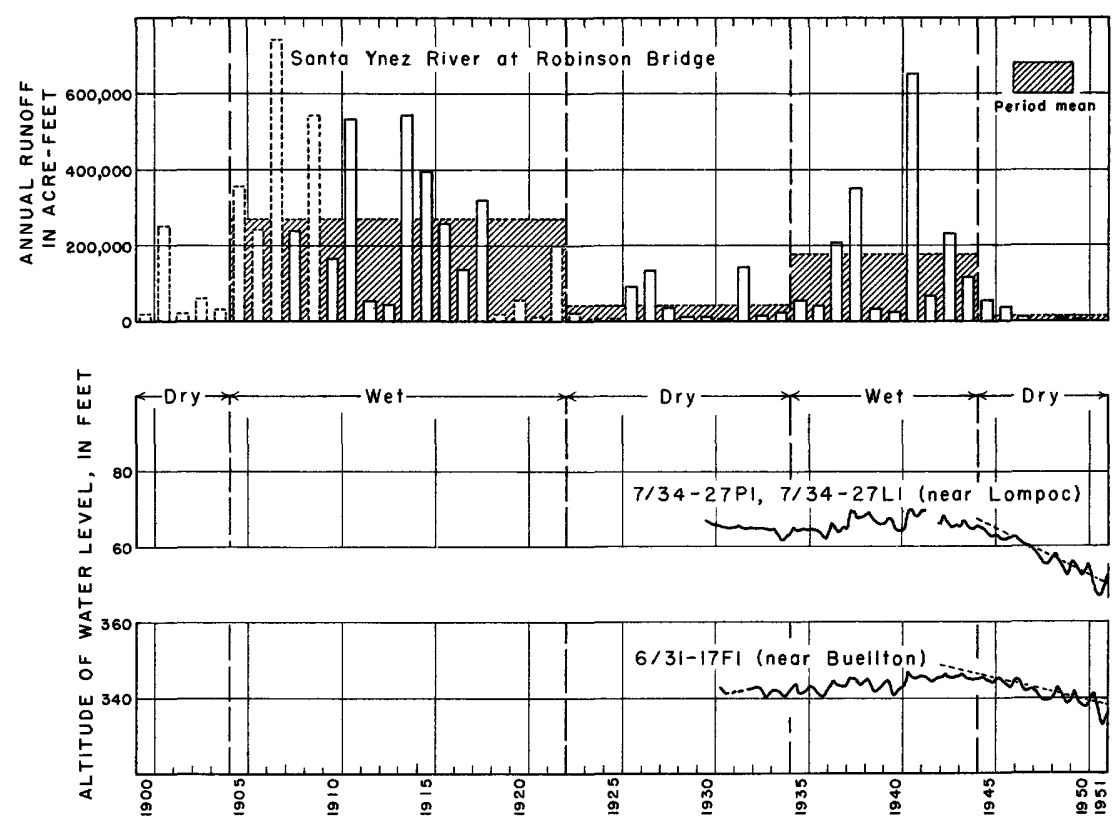

Figure 38. - Annual runoff of the Santa Ynez River and altitude of ground water at selected wells in the Santa Ynez River valley.

The records obtained at wells $7 / 34-27 \mathrm{P} 1$ and $7 / 34-27 \mathrm{~L} 1$, as representative of the changes in water level in the heavilypumped Lompoc plain, showed a decline of about $2 \frac{1}{2}$ feet per year during the latest drought. Lesser declines were observed at the western end of the plain where the ground water is confined by a fairly impermeable layer of clay (Upson and Thomasson, 1951). East of the Lompoc plain and adjacent to the Santa Ynez River is a long, thin thread of alluvial deposits which forms an excellent ground-water storage reservoir. Because these deposits are not too extensives, pumping during the growing season lowers the water table considerably, but the winter rains and mountain runoff usually restore the underground reservoir nearly to capacity. Since 1944 increased water requirements and below-normal precipitation and runoff have resulted in some water being removed from storage. The records obtained at well $6 / 31-17 F 1$ represent the change in water levels along the Santa Ynez River near Buellton. The water level at this well declined at a rate of more than 1 foot per year during the drought of 1944-51. The lowest water level of this drought is believed to be about 7 feet below the lowest level of the previous drought.

\footnotetext{
${ }^{3}$ Troxell, H. C. , and Wilson, H. D. , Jr. , 1951. Reports on stream runoff and ground-water storage capacity, Santa Ynez River, Santa Barbara County, Calif.: U. S. Geol. Survey openfile report.
} 


\section{CARPINTERIA AND GOLETA BASINS}

The Carpinteria and Goleta basins are two small coastal alluvial areas in the southeast corner of the region (fig. 34). Water-level records before 1941 for these coastal basins (Upson, 1951) are not available and, consequently, it has not been possible to compare the effects of the current drought with previous droughts. However, the record of declining water level obtained at well 4/25-27Q2 in Carpinteria and shown on figure 39 depicts the seriousness of the present drought. Since 1945 the water level in this well has declined at the rate of about 10 feet per year, a rate typical of most of the wells in the area. As a result, water levels

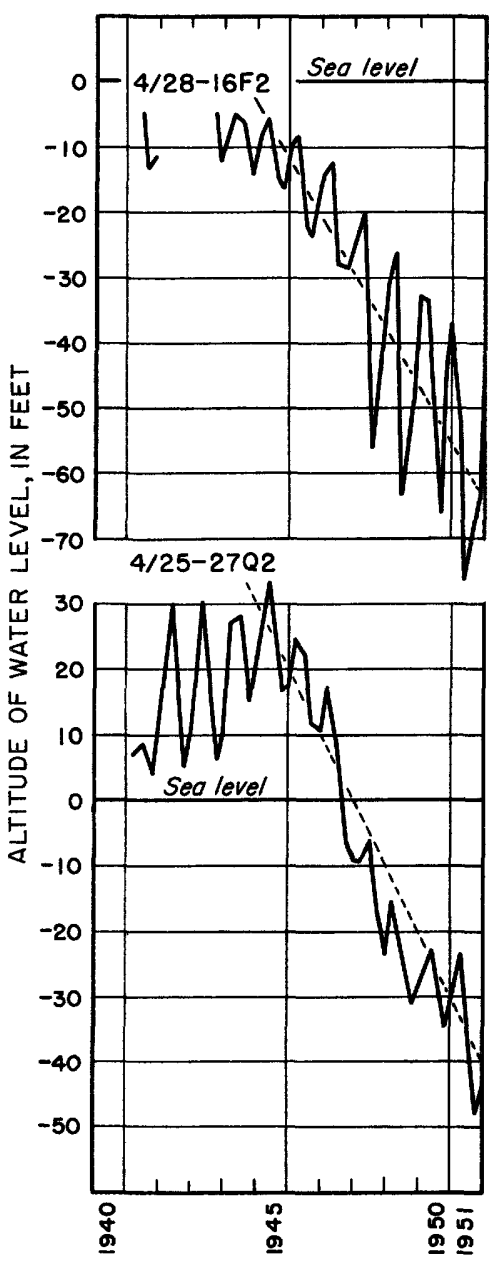

Figure 39. - Altitude of ground water at selected wells in the Carpinteria and Goleta basins. 
in more than half of the basin are below sea level. Should the present drought continue, there is a real danger of encroachment by sea water.

Conditions in the Goleta basin are very similar, although the rate of decline in water level is somewhat smaller. Water levels in about half of the basin are now below sea level but no contamination of potable supplies has been noticed to date. The records of change in water level for well 4/28-16F2 in the Goleta basin are also shown on figure 39. This record shows that since 1945 the water level has declined at a rate of about 8 feet per year.

The city of Santa Barbara is the principal domestic service unit operating in the Goleta basin. Ordinarily a major part of Santa Barbara's water requirements is satisfied by surface storage from Gibraltar Reservoir and seepage into two transmountain tunnels. However, in time of drought, when reservoir storage is generally low and runoff small, additional water from groundwater storage is necessary to satisfy the city's demands. During 1950 and 1951 more than half of the city's requirements had to be supplied from wells in Goleta basin. The completion of the Cachuma project, with its estimated yield of 33,000 acre-feet per year, is expected to help alleviate the ground-water shortage in these south coast communities.

\section{ANTELOPE VALLEY BASIN}

Antelope Valley basin is the extreme western end of the Mojave Desert in Los Angeles and Kern Counties and was named after the antelope that once inhabited it. As shown on figure 40 , the valley is just north of the San Gabriel Mountains and is otherwise surrounded by low barren mountain and foot hill areas. The lowest parts of the valley are the dry lakes or playas of Rosamond and Rogers (also known as Muroc) into which all the valley drains. The floor of the valley, comprising some 800 square miles, was originally covered with the usual desert plant life, such as sage, creosote, yucca.

The big impetus for settlement of this desert valley was the crossing of the valley by the Southern Pacific Railroad's San Joaquin Valley Line about 1876. Stock raising was probably the first agricultural activity, there being winter and spring grazing. By 1890 certain venturesome ranchers in the western part of the valley attempted to mature grain on the basis of winter rainfall and it is reported that in 1893 they shipped about 750 carloads of wheat. However, the extended dry period that began about this time completely wiped out most of these enterprises. 


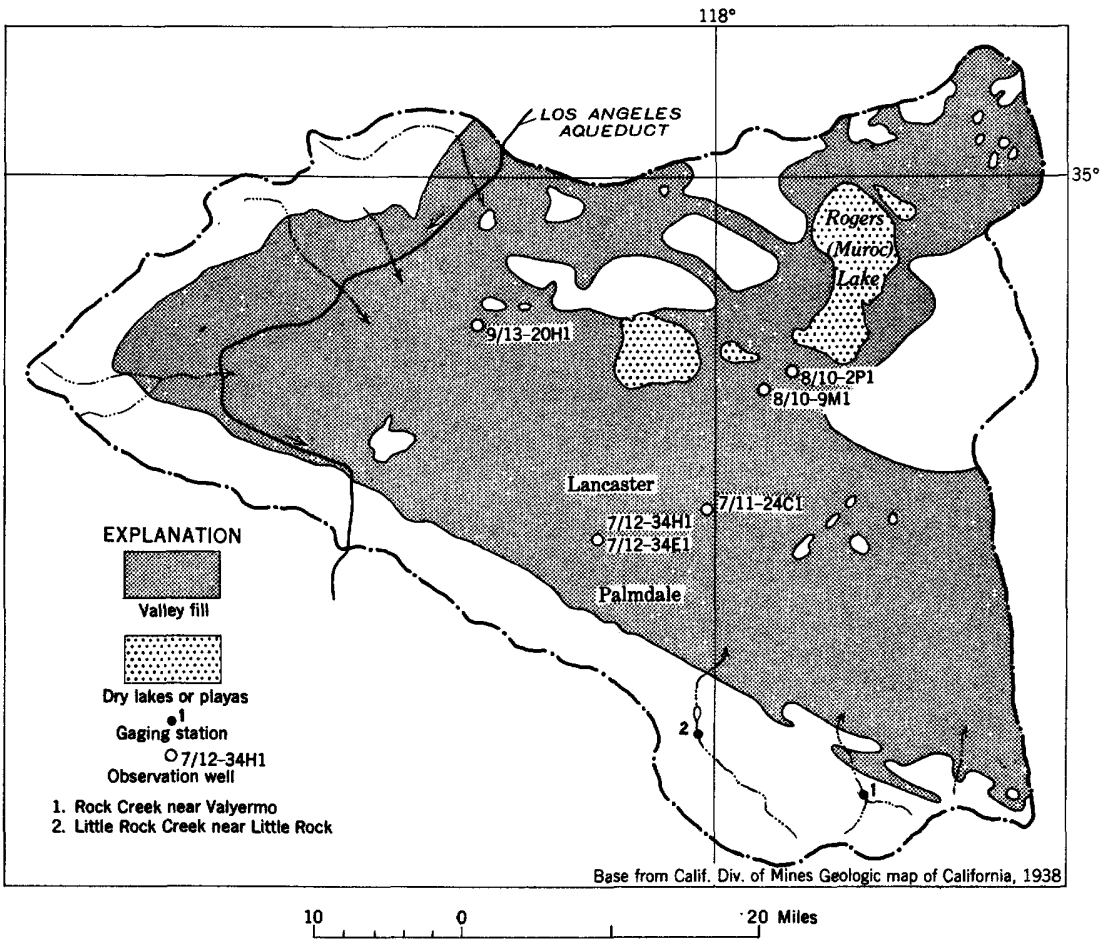

Figure 40. -Map of Antelope Valley basin showing valley fill, observation wells, and gaging stations.

Beginning about 1890 there was an extended period of land exploitation in which more than 2,000 acres of almonds and prunes were planted along the north toe of the San Gabriel Mountains in the area of heaviest precipitation. However, during the dry period of 1893-1904, hundreds of newly planted trees died and many acres were abandoned by discouraged colonists (Carpenter and Stanley, 1922; Johnson, 1911; Thompson, 1929).

\section{WATER REQUIREMENTS}

The discovery of artesian water during the early eighties in the vicinity of Lancaster created a verydesirable source of irrigation water. It has been reported that by 1908 there were more than 300 wells in the valley tapping these ground-water reserves, which are the valley's principal water source.

In 1890 the Palmdale Irrigation District was formed to supply water to about 50,000 acres from the runoff of Little Rock Creek in the San Gabriel Mountains. Actually not more than one-tenth of this acreage was supplied water from this source. Several years 
later in 1892 a second district known as the Little Rock Creek Irrigation District was organized to obtain any additional water that might be available from Little Rock Creek for use on about 3, 000 acres near. the town of Little Rock.

According to the California Conservation Commission (1912), there are about 485,500 acres of agricultural lands in the valley, most of which lies in Los Angeles County. Of this vast potential, only 4,629 acres were irrigated in 1912 and 54, 940 acres (U. S. Census) in 1949. The big increase in irrigated acreage took place between 1940 and 1951, when it increased from 30,982 acres to more than 52,000 acres in Los Angeles County (Los Angeles County Agricultural Commissioner, 1951). The principal agricultural crop is alfalfa.

On the basis of a crop survey, Gleason (1947b) estimated the annual consumptive use of the irrigated agricultural lands during 1945 at 109,000 acre-feet. Since that date there has been a substantial increase in the valley's water requirements.

The domestic and industrial water requirements are relatively small. The population of Antelope Township, representing that part of the valley in Los Angeles County, increased from 7,729 in 1940 to 16,084 in 1950 .

\section{WATER RESERVES}

The water resources for this vast agricultural acreage are confined largely to the surface runoff from the San Gabriel Mountains and the ground-water storage which underlies most of the valley. Because of its large reserve, ground-water storage is the most important of these. This storage, the accumulation of many years, is sustained by recharge from the storm runoff of the mountain areas and occasionally from heavy precipitation on the valley floor. The average annual precipitation on the valley floor areas ranges from about 10 inches along the toe of the San Gabriel Mountains to less than 5 inches near Rogers Dry Lake at Muroc Air Base (Los Angeles County Flood Control District, 1948). Because of this meager precipitation, any recharge that may exist on the valley floor will be confined to those infrequent wet years, such as 1940-41 when the rainfall exceeded 15 inches throughout the entire valley.

It is generally agreed that the main source of ground-water recharge is the runoff from the San Gabriel Mountains. The two principal streams which drain this mountain area are Rock and Little Rock Creeks. Their locations and sites of the gaging stations are shown on figure 40. During the period 1923-51 the annual 
runoff of Rock Creek ranged from 1,380 acre-feet in 1951 to 36,420 acre-feet in 1941; the mean annual runoff was 11,600 acrefeet. This extreme variability is shown in somewhat greater detail on figure 41 for both Rock and Little Rock Creeks. The mean
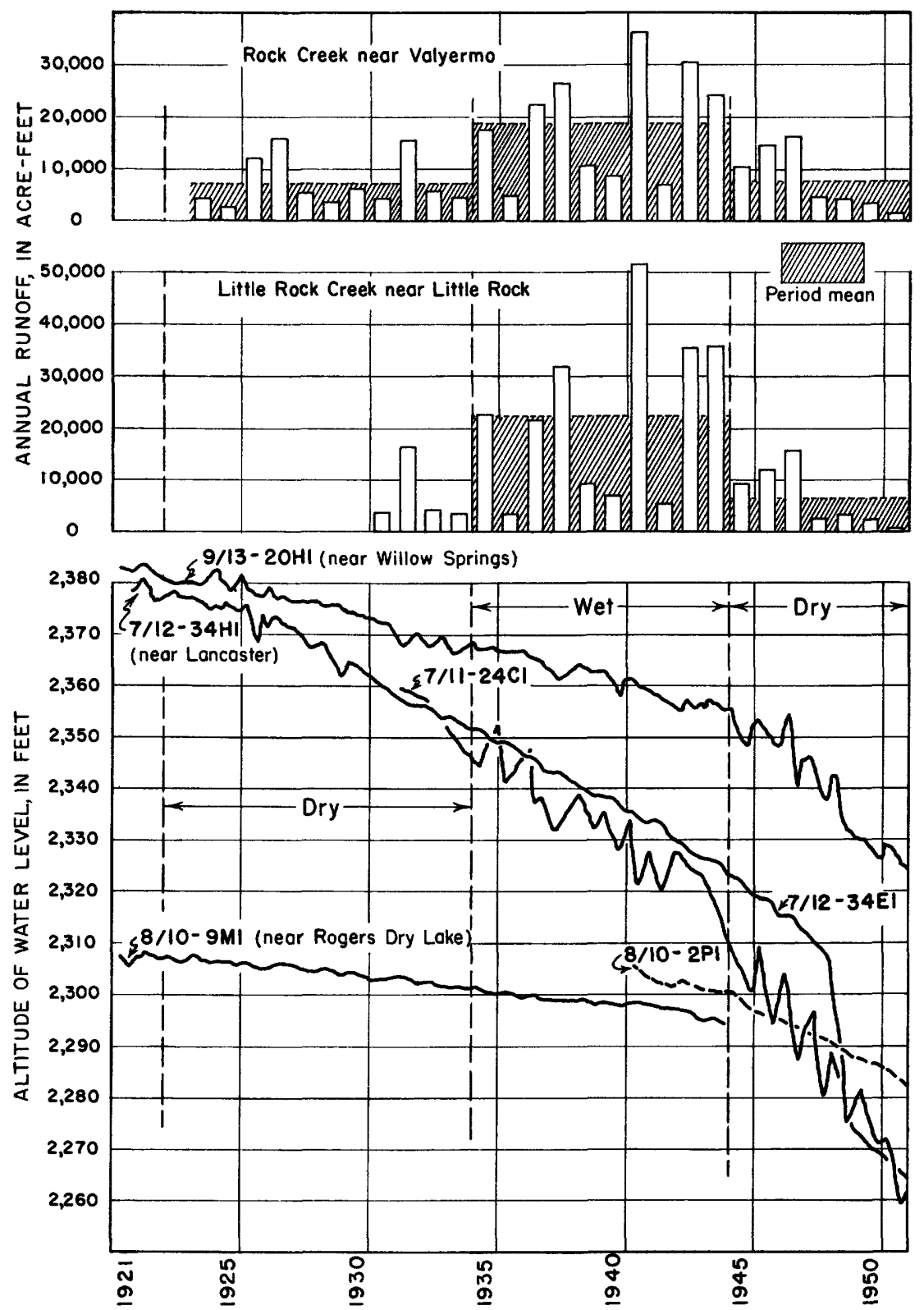

Figure 41. - Annual runoff of Rock $C_{r e e k}$ and Little Rock Creek and altitude of ground water at selected wells in Antelope Valley. 
annual runoff for these two streams during the period of record was about 26,000 acre-feet and represents the major contribution of the mountain runoff to the valley floor.

The changes in the ground-water reserves since 1921 are also shown in figure 41 by the graph of water levels at selected wells in the Willow Springs, Lancaster, and Rogers Dry Lake areas, the locations of which are shown on figure 40. These records show a continuous depletion of ground-water storage during the entire 30-year period.

\section{EFFECT OF DROUGHT OF 1944-51}

During the first dry period shown on figure 41 , the draft on the ground-water reserves exceeded the recharge to such an extent that the water levels in 9 representative wells declined 19.7 feet, or 1.6 feet per year. In the wet period of 1934-44 that followed, the average decline in the 9 wells amounted to 18.8 feet or 1.9 feet per year. Even though the precipitation and runoff were well above normal, the ground-water storage continued to decline and at an accelerated rate. To satisfy the existing water requirements, it was not only necessary to consume all of the greater ground-water recharge of this wet period, but additional amounts had to be obtained from storage.

During the 7-year drought of 1944-51, which followed this 10year wet period, the records of 68 wells showed an average decline of 32.1 feet, or 4.6 feet per year. This greatly accelerated annual decline was 2.9 times that for the preceding and equally dry period of 1922-34. There is every reason to believe that the precipitation on the valley floor and the mountain runoff around the periphery of the valley were almost identical in both these dry periods. Consequently, the recent critical depletion of the groundwater reserves in the valley is not so much due to hydrologic conditions, but rather to a steadily increasing water requirement. This belief is supported by Gleason $(1947 \mathrm{~b})$ who estimated that these increasing water requirements of the valley had created an annual overdraft of 41,000 to 46,000 acre-feet as early as 1945 . This continuous overdraft is creating a very critical shortage, the solution of which is not now in sight.

\section{MOJAVE RIVER BASIN}

The Mojave River was discovered by a Spanish priest and explorer, Francisco Garces, in March 1776. In attempting to establish a new route from the junction of the Gila and Colorado Rivers 
to the new capital of Alta California at Monterey, Garces followed the natural route now used by the Atchison, Topeka and Santa Fe Railway from the Colorado River, along the Mojave River and across Cajon Pass. Many of the early trappers, traders, and caravans following the Old Spanish Trailfrom Los Angeles to Las Vegas and east to Santa Fe used this route along the Mojave River. The Mojave River is the largest and most important stream in the vast Mojave Desert. Its origin is in the area of heavy precipitation on the leeward side of the high and rugged San Bernardino Mountains. Its drainage basin (fig. 42), which includes an area of about 4, 900 square miles, is predominantly desert, with a mean annual precipitation ranging from 4 to 8 inches. Precipitation of this magnitude is totally insufficient to support any of the agricultural crops required for man's subsistence. Consequently, all of the agricultural lands and most of the urban areas of the basin are confined to the Mojave River valley. Along both banks of the river from the San Bernardino Mountains to Newberry and the nowabandoned Camp Cady the ground-water reserves are continuously recharged by the runoff in the river. This long and relatively narrow river valley has been divided into the "Upper, Middle, and Lower Mojave River Valleys" by Thompson, (1929, p. 385), whose terminology will be used in this report.

The 1940 census gave the valley's population as 7,836 . Then, as a result of World War II and increased demand for agricultural crops, the population increased by 194 percent to 23,000 in a $10-$ year period. The principal urban areas of the valley are the towns of Barstow and Victorville which contain about 40 percent of the valley's population.

\section{WATER REQUIREMENTS}

As early as about 1860 , the small herds of cattle grazing in the moist areas along the river were of ten in danger of being raided by the Paiute Indians (Storie and Trussel, 1933). In order to offer a measure of protection to these areas, a military garrison was established at Camp Cady on the river about 15 miles downstream from Daggett.

The entire river valley was opened for settlement in 1885 upon the completion of the transcontinental Atchison, Topeka and Santa Fe Railway. Then under the influence of the Great Boom of 1887 there came a long series of fantastic water development projects which generally ended in bankruptcy.

The census of 1919 indicated that there were 4,608 acres of irrigated land in the valley. This acreage slowly increased tc 


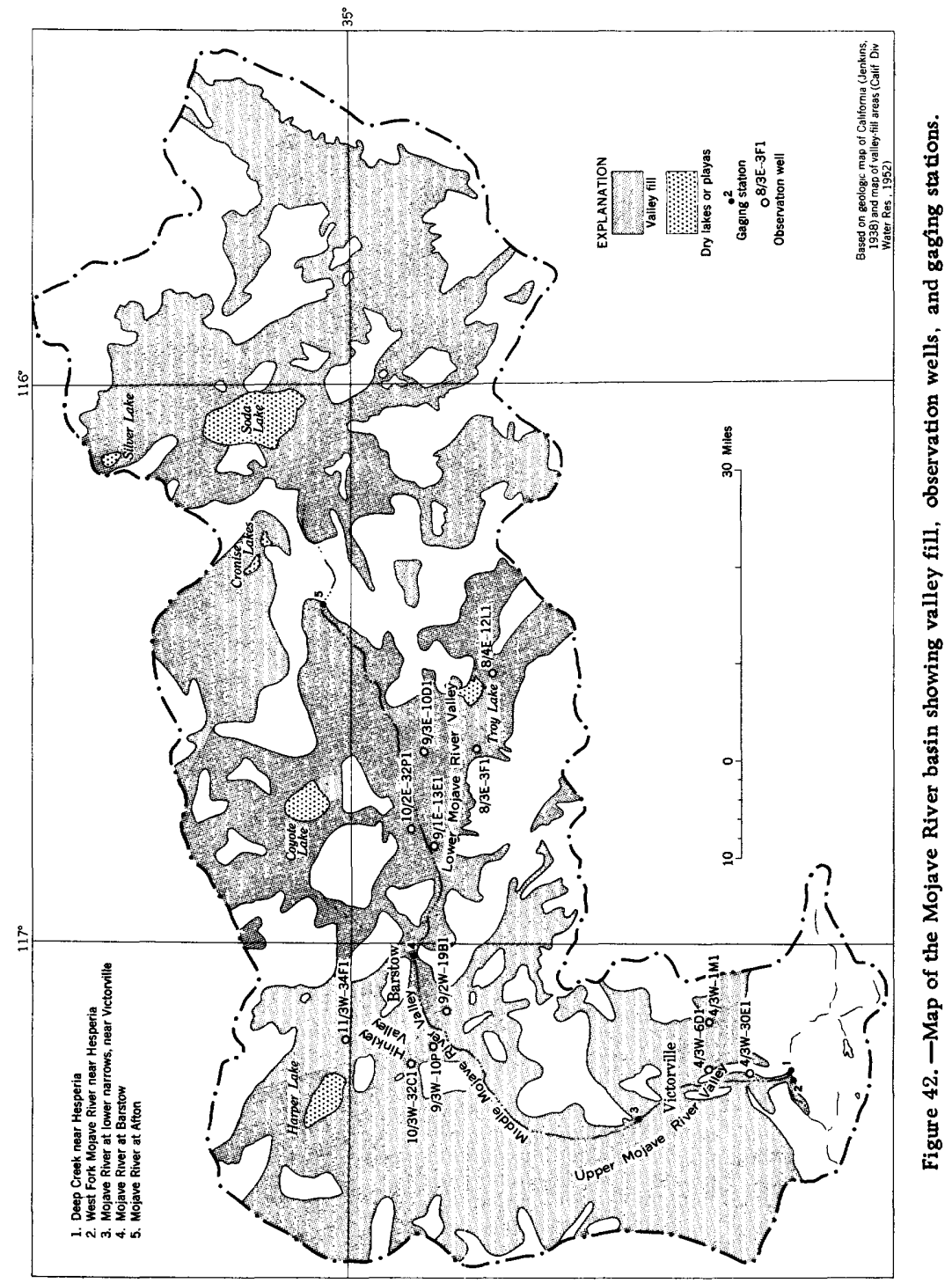


6,456 acres by 1939 . Then with the beginning of World War II and the general shortage of agricultural crops, a new impetus was given to the valley. In 1951 the San Bernardino County Agricultural Commissioner estimated that the irrigated acreage had increased to almost 18,000 acres. The 1951 annual agricultural water requirements have been estimated to be about 56,000 acrefeet (U. S. Bur. Recl., 1952).

With the rapidly increasing population, the domestic and industrial water requirements have also increased. In addition, several military establishments have been installed in the valley as a result of the recent war. The valley's combined water deliveries for domestic, industrial, and municipal purposes were estimated to be about 5,600 acre-feet in 1949 (U. S. Bur. Recl., 1952). The unconsumed portions of this water will be returned through the sewer systems to ground-water storage or made available for reuse. It is estimated that only about 2,000 acrefeet of these deliveries will be used consumptively. On this basis the combined annual water requirements as of 1951 should be in the order of 58,000 acre-feet.

\section{WATER RESERVES}

As already indicated, the major part of the basin's precipitation falls within the 212 square miles located in the San Bernardino Mountains. In this mountain area the mean annual precipitation ranges from about 45 inches along the coastal divide to 10 inches along the contact between the mountain and desert areas (Troxell and others, 1954). An isohyetal map prepared by Troxell and Hofmann (1954) indicates that the mean annual precipitation ranges from 4 to 8 inches over the remaining parts of the basin.

Practically the entire recharge to the basin's water reserve is confined to the larger precipitation of the mountain area which delivers storm and flood runoff in great volume onto the arid valley floor, there to recharge the soil moisture in the streambed deposits and replenish the ground-water reservoirs beneath. On those occasions when the flood runoff is large, it passes successively beyond the towns of Victorville, Barstow, and Yermo, wasting into the usually dry playas of Soda and Silver Lakes, about 160 miles from the mountain area.

This contribution to the valley floor water reserves has been measured as it leaves the mountain area continuously since 1904, except for the period of 1922-30 when the stations were temporarily discontinued. It is shown on figure 43 for the period of 1918-51 and is based on the combined flow of the "West Fork 

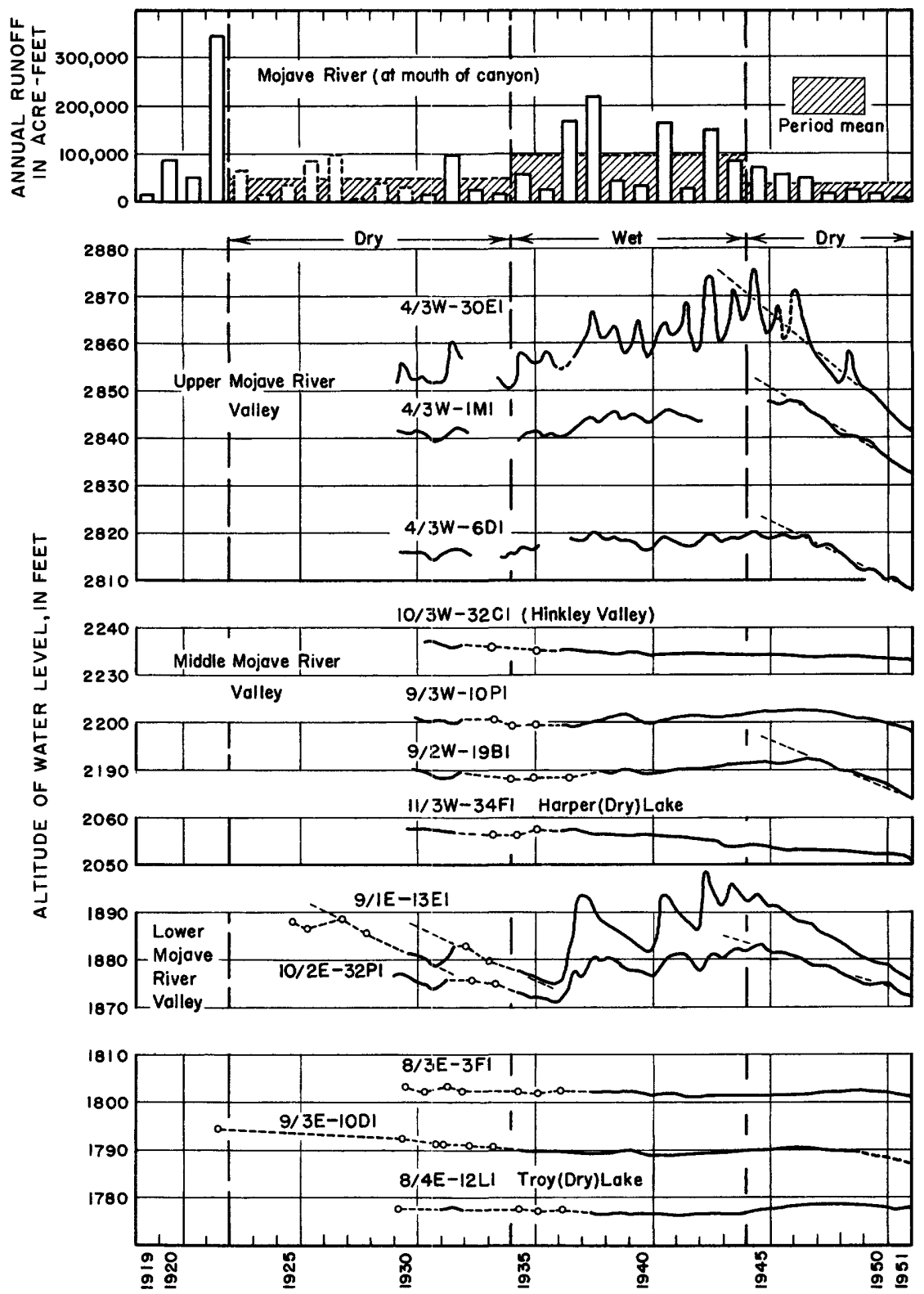

Figure 43. - Annual runoff of the Mojave River and altitude of ground water at selected wells in the Mojave River valley.

Mojave River near Hesperia" and "Deep Creek near Hesperia" (gaging station sites 1 and 2 on fig. 42). The records for the missing period included on figure 43 have been estimated on the 
basis of all the available data. The combined annual runoff at this site has proved to be extremely variable, ranging from a minimum of 2,220 acre-feet during the water year 1951 to a maximum of 345,000 acre-feet during the water year 1922, with an average of 82,000 acre-feet for the 1904-51 period.

\section{EFFECT OF DROUGHT OF 1944-51}

The main water reserves of the Mojave River valley are the ground-water storage of the valley's alluvial fills. It has been estimated that the first 100 feet below the ground surface in that part of the valley from Barstow to the San Bernardino Mountains has a potential ground-water storage capacity of $1,130,000$ acrefeet (Calif. Div. Water Res., 1934). This potential ground-water storage capacity is more than 19 times greater than the 1951 water requirements.

\section{UPPER MOJAVE RIVER VALLEY}

As indicated on figure 42, the Upper Mojave River Valley is the relatively broad alluvial plain along the river between the San Bernardino Mountains on the south and the Granite Mountains to the north. The area is the site of the earliest irrigation efforts and includes Apple Valley and the towns of Victorville and Hesperia. The water-bearing alluvial deposits are believed to be fairly deep-more than 800 feet in parts of the valley. The natural ground-water levels in the valley are largely controlled by a $\mathrm{V}$ shaped outlet channel cut in the resistant granitic rocks near Victorville and known as the Upper Narrows. However, some ground water may pass around the west side of the Granite Mountains, from the upper to the middle valley.

The Upper Mojave River Valley is more favorable to recharge than the lower parts of the valley. The mean annual inflow to the valley ranged from 32,400 acre-feet during the drought of 1944-51 to 96,600 acre-feet during the 1934-44 wet period. (This inflow does not include the diversions of the Hesperia Water Company made about $2 \frac{1}{2}$ miles upstream.) Because of this wide range in average inflow between these wet and dry periods, it has not been physically or economically feasible to regulate this runoff by surface storage to produce more uniform rates of inflow.

As a consequence, excessive flood runoff originating in the mountain area currently passes completely through the valley. This resulted in a mean annual outflow from the valley of 82,400 acre-feet during this 1934-44 wet period at Victorville (site 3, fig. 42). The 14,200-acre-foot difference between the inflow and 
outflow during this wet period represents the recharge from the river, or retention to the valley's water reserves. Except for the very minor runoff from the desert mountain areas tributary to the valley and the deep penetration of precipitation falling on the valley floor, this was the only source of recharge to the Upper Mojave River Valley. The retention may be subject to some slight modification by subsurface inflow and outflow in the river channel at the gaging stations, although Slichter (1905) found the subsurface outflow at Victorville narrows to be less than $1 \mathrm{cfs}$.

The mean annual retention ranged from 14,200 acre-feet during the wet period to 0 during the dry period. However, the annual retention for individual years ranged from a maximum of 30,100 acre-feet in the 1938 water year to a minimum of minus (-) 18,600 acre-feet in the 1951 water year. This negative quantity of 18,600 acre-feet indicates that the ground-water seepage at Victorville exceeded the inflow by this amount.

For the complete 17-year cycle the mean annual retention amounted to 8,400 acre-feet. This mean annual retention is essentially the average annual water requirements, together with the natural water loss through uneconomic riparian plant life in the moist areas, providing the ground-water levels were about the same at the beginning and ending of the period. However, as shown on figure 43 , the water levels in three representative wells in the upper valley were the lowest in the entire period of record at the end of the 1944-51 dry period.

The first of these records was obtained at well 4/3W-36E1 in the upper part of the valley along the Mojave River channel near the mouth of Antelope Wash. Because of its location, this well reflects the annual winter recharge, and for this reason probably shows the greatest seasonal range in water levels in the entire valley. The latter part of this record clearly shows the effect of the accelerated water requirements, with the water level of September 1951 being about 8 feet below the levels in the preceding drought. An extremely small rate of water-level decline in $1930-$ 34 in a period of drought increased to 5.5 feet per year during the drought of $1944-51$.

At well 4/3W-1M1 in the Apple Valley section of the valley about 6 miles east of the river, the record is similar to that for the preceding well except for a somewhat less accelerated rate of decline during the latter part of 1944-51.

The record from the third well-4/3W-6D1-about 2 miles east of the river and just upstream from the moist areas, confirms the records obtained at the other two wells. 
The Middle Mojave River Valley is that part of the Mojave River Valley extending from the Narrows near Victorville to Barstow. For a distance of about 25 miles below Victorville this narrow valley is seldom more than 2 miles wide. In this section of the valley are the towns of Oro Grande, Bryman, Helendale, Wild, and Hodge. Below Hodge the valley widens into a broad triangular-shaped plain. One limb of this triangle, probably representing an ancient stream channel of the Mojave River, goes northward into Harper (dry) Lake. This part of the valley is known as Hinkley Valley. In the extreme northern end of Hinkley Valley and in the vicinity of Harper (dry) Lake, which is also considered as a part of the Middle Mojave River Valley, the water-bearing alluvial deposits are believed to be 2,000 feet in depth (Calif. Div. of Water Res., 1934). The other limb of the triangle represents the eastward course of the present Mojave River channel.

Most of the middle valley's agricultural developments are restricted to the narrow river channel between Victorville and Hodge or in the Hinkley or Harper valleys.

Almost the entire inflow to the valley's ground-water reserves comes from the outflow of the Upper Mojave River Valley. The inflow represents the intermittent flood runoff from the mountain area and the continuous effluent ground-water seepage from the upper valley.

The mean annual inflow was 82,400 acre-feet during the wet period and 32,400 acre-feet during the dry period. Because of the high rate of discharge during the wetperiod, the mean annual outflow from the middle valley was 47,200 acre-feet. In the dry period that followed, the mean annual outflow decreased to 5,400 acrefeet. The mean annual retention in the valley amounted to 35,200 acre-feet in the wet period and 27,000 acre-feet in the dry period. Retention ranged from a maximum of 50,000 acre-feet in the flood water year of 1938 to a minimum of 15,000 acre-feet in the 1936 water year, as contrasted, respectively, with 31,100 and $-18,600$ acre-feet in the upper valley. The average annual retention for the cycle was 31,800 acre-feet, which is about 51 percent of the inflow at Victorville.

The records obtained at four representative wells in the middle valley are shown in the midsection of figure 43 . In general, the range in water level is much less than in the wells of the upper valley. This may be due partly to the greater uniformity in the annual recharge. 
The water level in well $10 / 3 \mathrm{~W}-32 \mathrm{C} 1$ in the extreme western part of Hinkley Valley about $1 \frac{1}{2}$ miles west of the town of Hinkley has steadily declined since the first observation made in 1931. In this way it is unlike the wells in the upper part of the valley. This decline, however, is small, only 3 feet in the 20-year period.

The record of well $9 / 3 W-10 P 1$ near the river about 4 miles north of Hodge, shows the same limited range in water-levelfluctuations. The record does, however, show a recovery during the period of recharge in the wet years and a decline during the dry years.

The record of well $9 / 2 \mathrm{~W}-19 \mathrm{~B} 1$, on the south side of the river midway between Hodge and Barstow, is astonishingly similar to the record obtained at well $4 / 3 \mathrm{~W}-6 \mathrm{D} 1$ in the moist area above Victorville. The water-level record reflects the increased recharge during the wet years and a much more rapid decline during the dry years. At the conclusion of the record the water level was about 4 feet below the previous flow.

A fourth record was obtained at well $11 / 3 \mathrm{~W}-34 \mathrm{~F} 1$ in the Harper (dry) Lake area. Like the water levels in Hinkley Valley this level has declined almost continuously since 1930 but not at the accelerated decline experienced in so many wells during the drought of 1944-51. The water level, however, has declined about 7 feet in the last 21 years.

\section{LOWER MOJAVE RIVER VALLEY}

The Lower Mojave River Valley represents that section of the Mojave River valley between Barstow and long-abandoned Camp Cady. For a distance of about 9 miles between Barstow and Daggett this valley is generally less than a mile wide. At the lower end of this confined section, the stream discharges onto a second triangular-shaped valley. The northeast limb of this triangle is the present channel of the Mojave River along which is located the transcontinental Union Pacific route. The main towns in this part of the valley are Yermo and Harvard. The southeast limb of this triangle probably represents an antecedent channel which passed near the town of Newberry into Troy (dry) Lake. The transcontinental route of the Atchison, Topeka and Santa Fe Railway follows this route from Daggett to Needles. The entire inflow, or recharge, of this valley is generally confined to the excess mountain flood runoff reaching Barstow.

The estimated mean annual outflow from the valley was 11,000 acre-feet for the wet period and 2,000 acre-feet for the dry period and is based on the record obtained at Afton (site 5, fig. 42). As 
a result, the mean annual retention amounted to 36,200 acre-feet during the 10-year wet period and 3,400 acre-feet during the 7 -year dry period. The average annual retention, for the entire 17-year periodwas 22,700 acre-feet, or 75 percent of the inflow at Barstow.

The variability in the annual retention is greater than in any other part of the Mojave River Valley. This annual retention is believed to range from about 100,000 acre-feet in the 1938 water year to minus (-) 1,000 acre-feet during the current drought.

The lower part of figure 43 gives the water-level fluctuations in five representative wells in the lower valley. The first record is that obtained at well $9 / 1 \mathrm{E}-13 \mathrm{E} 1$ in the upper section of this valley about 3 miles east of Daggett. During the 1932-35 part of the preceding drought, the water level in this well declined at a rate of 2.2 feet per year. Beginning with the spring of 1937 the water level showed a recovery of about 24 feet during the wet period. Then, beginning with the drought of 1944-51 the water level steadily declined at a rate of 4.0 feet per year. However, even with this accelerated decline due to the increased water requirements, the water level was slightly higher than the minimum occurring in the fall of 1936 .

The record of well 10/2E-32P1, about 2 miles east of Yermo and along the northern side of the valley, is similar to that of the preceding well. Both of these wells are upstream from the Forks of-the-Road fault which crosses the valley.

The next record on figure 43 is that of well 8/3E-3F1 downstream from the Forks-of-the-Road fault. Since 1930 the water level in this well has changed very little. The water-level fluctuations only faintly reflect the distribution obtained above the fault and with considerable lag.

Well $9 / 3 E-10 D 1$ is in the middle of the valley about midway between Harvard and Newberry. The water level in this well, also located below the fault, has declined about 8 feet since 1922 . The water-level fluctuations are small, yet tend to indicate an acceleration in the rate of decline during the latter part of the drought of $1944-51$.

The final record on figure 43 was obtained at well $8 / 4 \mathrm{E}-12 \mathrm{Ll}$ in the Troy (dry) Lake area about 9 miles east of Newberry. This record shows very little range in fluctuation, and, as a result of a probable lag, the maximum rise due to the wet period was not shown until 1948 and 1949 in the midst of the drought of 1944-51.

\section{WHITEWATER RIVER BASIN}

The Whitewater River (fig. 44) heads at altitudes above 10, 000 feet in the rugged and steep San Jacinto and San Bernardino 


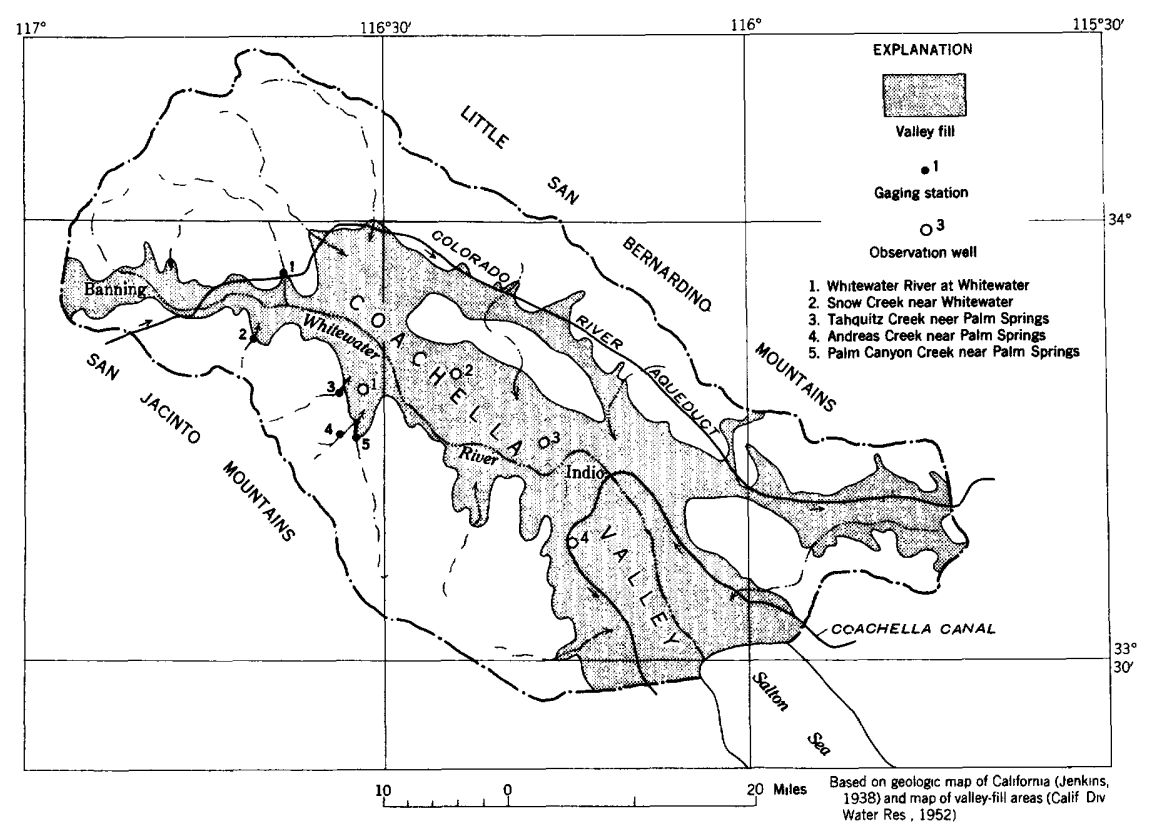

Figure 44. -Map of Whitewater River basin showing valley fill, observation wells, and gaging stations.

Mountains and, in a distance of about 50 miles, wastes into the Salton Sea at an altitude of 239 feet below sea level. Troxell and others (1954) indicate that the mean annual precipitation in these two mountain blocks ranges from about 15 inches along the toe to 45 inches at the divide. The flood runoff from this precipitation discharges onto the alluvial deposits extending from the relatively low San Gorgonio Pass (altitude 2,600 feet) near Beaumont on the west to the Salton Sea on the east.

An extreme eastern limb of these alluvial deposits just upstream from the Salton Sea, and hemmed in by the Little San Bernardino Mountains on the north and the Santa Rosa Mountains on the south, is the famous Coachella Valley. The valley is the upper part of a long alluvial limb of the Colorado Desert extending north and westward from the Gulf of California, and its continuous aridity is due to the high mountains to the north and west blocking the incoming moisture-laden ocean air masses.

In the southern part of this valley is the site of ancient Lake Cahuilla, which has been dry for many years except in the extreme lower part which now contains the recently formed Salton Sea. The altitude of the water in this sea steadily declined from a maximum of 195. 0 feet below sea level in February and March 1907, after the repair of the breakthrough of the Colorado River, to a minimum of 250.7 feet below sea level in November 1924. Then, the water 
level gradually recovered to 238.8 feet below sea level on October 1, 1951.

The valley's alluvial deposits consist of the debris carried in the meandering and crisscrossing stream channels from the local mountain areas, together with the finer sediments of the Colorado River. The valley floor has an area of about 344 square miles, or 220,000 acres.

\section{WATER REQUIREMENTS}

The first detailed reports of the Whitewater River and Coachella Valley were made in 1853 by the Williamson expedition while engaged in locating a new transcontinental railroad route through San Gorgonio Pass. The valley was opened to occupation by the completion of the Southern Pacific Railroad in 1879. Under the Desert Land Act, claims were filed on large parts of the public lands in the valley in the boom days of 1880-90. However, it was the completion of a successful deep well at Walters in 1894 , proving the presence of artesian water, that furnished the real stimulus to desert reclamation (Mendenhall, 1909). Mendenhall reported that 350 to 400 deep wells had been completed in the valley, about three-quarters of which were artesian wells.

Coachella Valley is the home of one of the most promising and picturesque agricultural industries in the entire State, for it is the only place in the United States where the Deglet Noor, a choice type of date palm, can be successfully grown. In 1904 the Federal government established an experiment station for the purpose of studying and developing date palm culture in the valley and imported the choicest varieties of date palms from Egypt, Algeria, and the area around the Persian Gulf. The Riverside County Agricultural Commissioner's records indicate that the date palm acreage has increased from 50 acres in 1915 to 4,885 acres in 1951 , and that the 1951 crop was valued at $\$ 6,200,000$ or $\$ 1,269$ per acre.

The annual rate of transpiration of this highly valuable crop is more than 70 inches of water, as shown on figure 11. This is typical of the high water requirements of all the crops grown in this very dry area. The shallow-rooted citrus requires an irrigation application of about 99 inches annually, alfalfa requires about 96 inches, and cotton requires about 56 inches (Pillsbury, 1941). The actual loss through evapotranspiration may be 70 or 80 percent of these water applications.

The census indicates that about 28,000 acres of agricultural land, out of a potential acreage of 142,600 acres (Calif. Conserv. Comm., 1912) were irrigated in 1949. This irrigated acreage 
produced a crop in 1951 valued at $\$ 23,600,000$ by the Riverside County Agricultural Commissioner and had an estimated water requirement of about 158,000 acre-feet. These water requirements are based on a crop survey by the commissioner and the use of suitable evapotranspiration values for each crop.

The warm winter sunshine of this desert area has long been an attraction to many people. As a result, many communities have de veloped in the barren wastes of the valley wherever water could be obtained. The 1950 census indicates that the valley is the permanent residence of more than 26,000 persons; in addition there is a large tourist population.

The largest of these communities is the city of Palm Springs at the base of the rugged and steep San Jacinto Mountains which tower 10,000 feet above the city. The runoff in mountain streams nearby is the source of about 80 percent of the city's water supply. The 175 service connections of the Palm Springs Water Company in 1920 have increased in a 31-year period to 1,908 in 1951. This phenome$\mathrm{nal}$ increase in water needs is shown on figure 45 in the form of annual deliveries for the period of 1930-51. The water use in most of

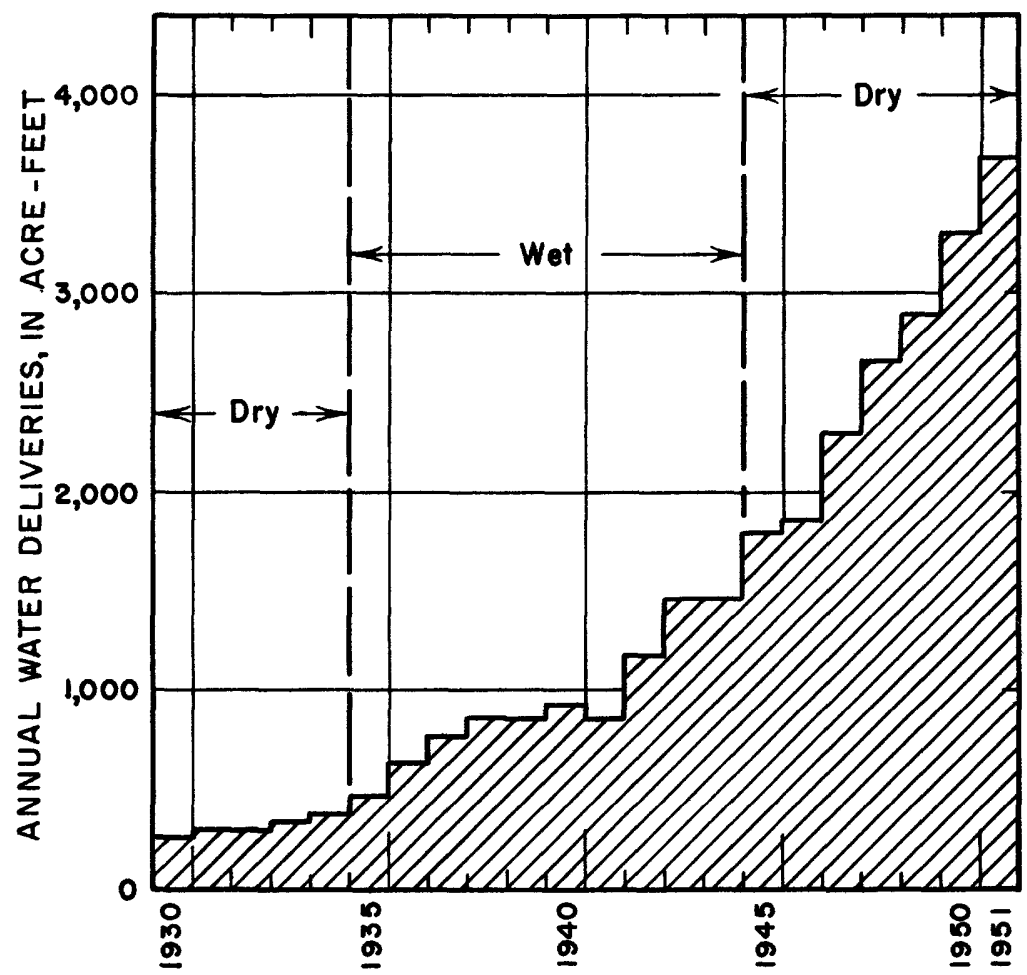

Figure 45. - Annual water deliveries to city of Palm Springs. 
the Whitewater River basin and Coachella Valley communities is believed to be similar to that shown on this diagram.

Most of the valley's agricultural activities are centered around - the thriving city of Indio, which is one of its oldest communities. Indio's population has more than doubled in the last decade and was 5,300 in 1950 .

These rapidly expanding cultural developments create an everincreasing demand for water. On the basis of the annual crop surveys of the Riverside County Agricultural Commissioner and the assumption that about half of the domestic water deliveries are used consumptively, it has been possible to derive the estimated annual water requirements since 1909. These data (fig. 46) indicate the

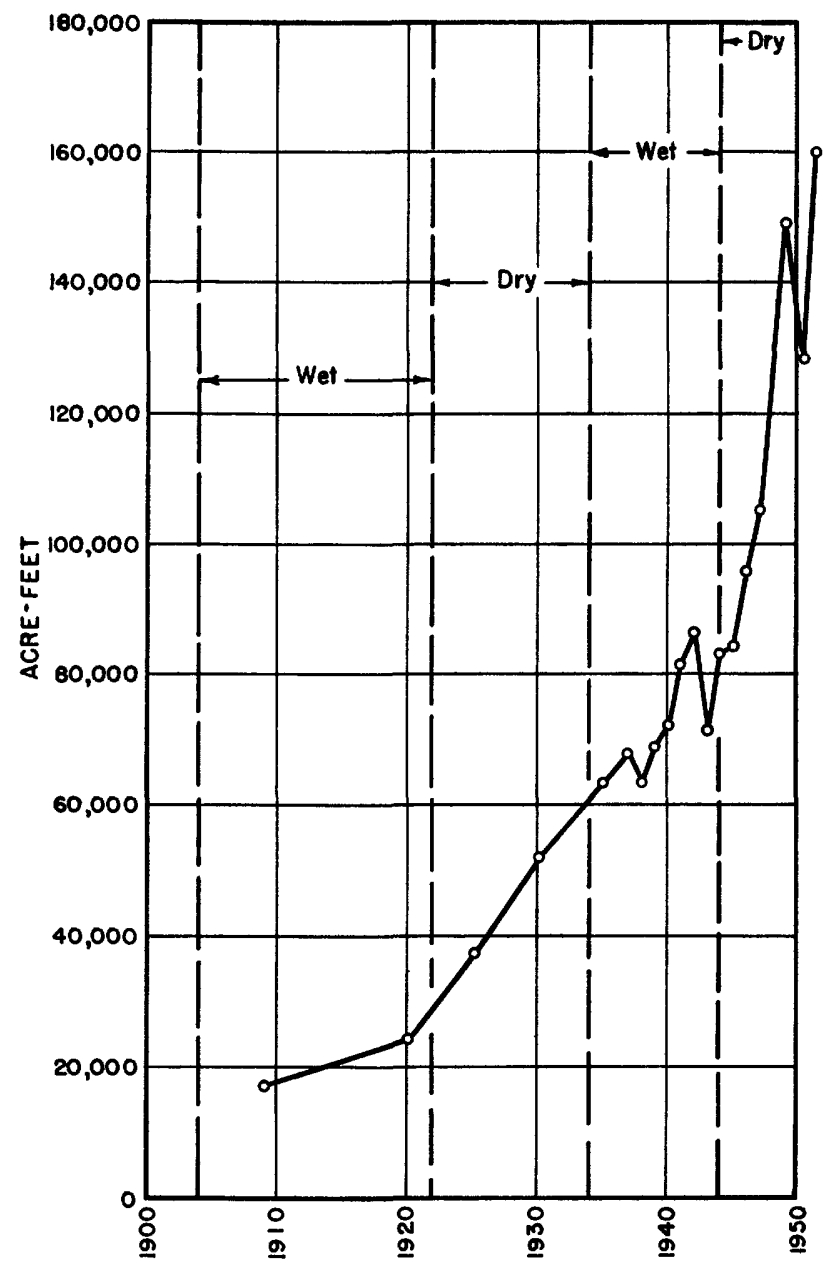

Figure 46. - Estimated annual water requirements of Coachella Valley. 
same rapid increase in the demand for water found throughout most of southern California. These water requirements more than doubled during the drought of 1944-51.

\section{WATER RESERVES}

Before the completion of the All-American and Coachella Canals, all the water reserves of the Whitewater River basin had their origin within the basin. Most of these reserves were developed by runoff from the higher mountain areas where some of the streams are perennial. Recently a stream-gaging program was undertaken to measure the contribution of these mountain streams to the valley's water supply. On the basis of these meager data and recently developed precipitation-runoff relations (Troxell, 1948), the mean annual recharge to the alluvial fill of the valley has been estimated, as shown in table 16 .

Table 16. - Estimated mean annual runoff into Coachella Valley

\begin{tabular}{|c|c|c|c|c|}
\hline \multirow{2}{*}{ Stream } & \multirow{2}{*}{$\begin{array}{l}\text { Period of } \\
\text { record }\end{array}$} & \multirow{2}{*}{$\begin{array}{c}\text { Drainage } \\
\text { area } \\
\text { (square } \\
\text { miles) }\end{array}$} & \multicolumn{2}{|c|}{$\begin{array}{l}\text { Estimated mean } \\
\text { annual runoff }\end{array}$} \\
\hline & & & Inches & Acre-feet \\
\hline 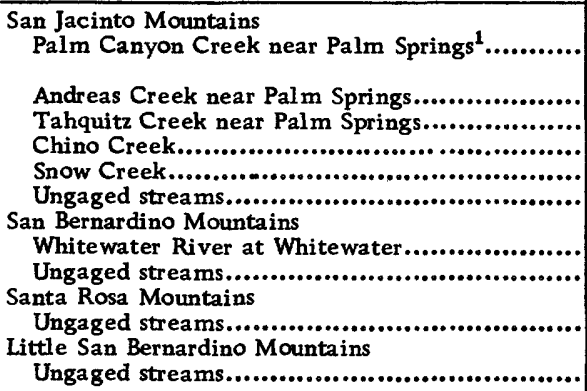 & $\begin{array}{l}1930-42, \\
1947-51 \\
1948-51 \\
1947-51 \\
\text { No record } \\
1921-34 \\
\ldots \ldots \ldots \\
1948-51 \\
\ldots \ldots \ldots \ldots\end{array}$ & $\begin{array}{c}94 \\
\\
8.78 \\
17 \\
4.7 \\
11.5 \\
85 \\
57.4 \\
235 \\
204 \\
400\end{array}$ & $\begin{array}{c}1.16 \\
4.25 \\
13.0 \\
7.7 \\
12.2 \\
5.4 \\
4.8 \\
2.5 \\
.8 \\
.1\end{array}$ & $\begin{array}{r}5,800 \\
2,000 \\
12,000 \\
2,000 \\
7,500 \\
24,000 \\
15,000 \\
31,000 \\
8,700 \\
2,100\end{array}$ \\
\hline Total.................. & & 1,120 & 1.8 & 110,000 \\
\hline
\end{tabular}

${ }^{1}$ Partly in the Santa Rosa Mountains.

As indicated in table 16 , the mean annual recharge to the valley floor areas is about 110,000 acre-feet. If this amount is relatively correct, then the annual water requirements, which include both agricultural and domestic, as well as all the natural water loss on the valleyfloor, have exceeded the annual recharge for a number of years. This means an overdraft of the valley's water reserves and a shortage that could soon become critical. However, this shortage is now largely alleviated by the importation of Colorado River water through the All-American and 
Coachella Canals. In the first 12 -month period of this canal's existence, it delivered 198,000 acre-feet to the valley from September 1951 to August 1952.

\section{EFFECT OF DROUGHT OF 1944-51}

In this desert region of continuous aridity, any diminution of the precipitation in the valley floor areas during this drought period would have little effect on the water requirements or water reserves. However, in the zones of greater precipitation in the San Jacinto and San Bernardino mountain areas to the west of the valley there will be a wide variation in annual runoff between the wet and dry periods. During periods of drought the mountain runoff and recharge to the valley's water reserves will be considerably below the mean. Consequently, a decline in water reserves is to be expected during these dry periods.

Until very recently, these water reserves were confined to the ground-water storage in the valley fill. For that reason the changes in water level for 4 representative wells are shown on figure 47 . The locations of these wells are shown on figure 40 .

The record of observation well 1 (Palm Springs Water Company's well 2), located in the coarse valley fill recharge area at the toe of the San Jacinto Mountains near the mouth of Tahquitz Creek, is the first graph shown on figure 47 . The record is scanty before 1945, but since that date the water level has steadily declined more than 30 feet under the influence of heavy pumping and lack of recharge. As is to be expected, in this periphery area the rate of decline during the 1944-51 drought is the greatest in the entire valley.

The second record is from well 2 at Edom, about 30 miles from the Salton Sea. Observations made in the vicinity of this well since 1879 indicate that the water level remained fairly constant through 1935. However, during the drought of 1944-51 the water level at this well declined more than 10 feet.

The third record was obtained at well 3 just northwest of Indio and about 22 miles from the Salton Sea. This well is just outside the boundaires of the 1905 artesian area (Mendenhall, 1909). The water level in this well has almost uniformly declined since the winter of 1926.

The last record is of well 4, about 5 miles southwest of Coachella and about 15 miles from the Salton Sea. The water level in this well, which is near the 1905 artesian area, has also shown a 


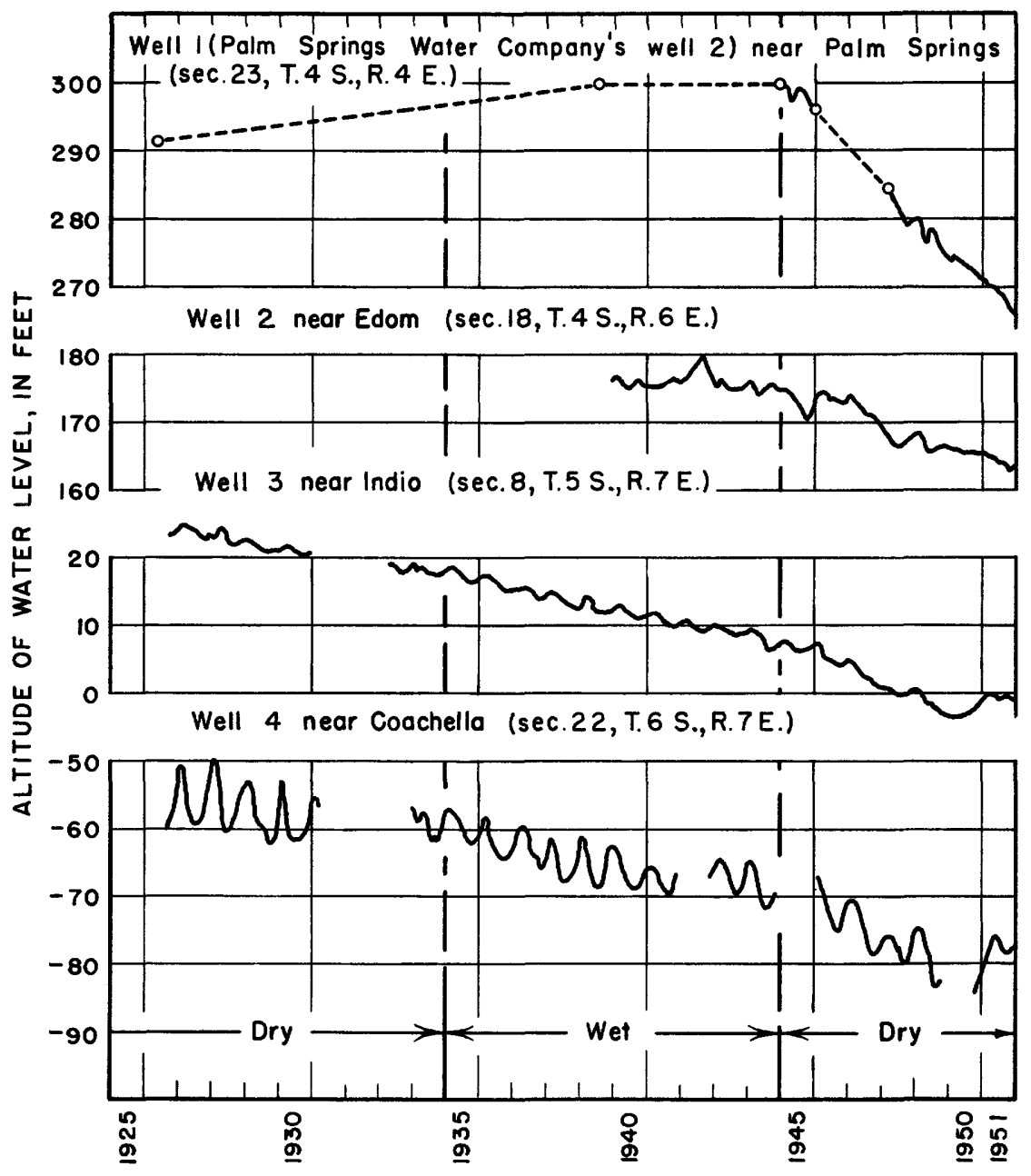

Figure 47. - Altitude of ground water at selected wells in the Coachella Valley.

fairly steady decline since 1925. The rate of decline appears to have been only slightly accelerated during the last drought period.

The effect of the lack of recharge and the large increase in water requirements during the drought of 1944-51 appear to have created a 10-to-30-foot decline in ground-water storage and an overdraft in the local water reserves.

\section{IMPERIAL VALLEY}

Immediately south of Coachella Valley and the Salton Sea, in the midsection of the long alluvial desert valley extending northward 
from the Gulf of California, is the Imperial Valley. This valley formed the southern part of the bed of ancient Lake Cahuilla, with most of the land surface being well below sea level. Brawley, one of the largest cities in the valley, lies more than 100 feet below sea level. The valley has also been generally identified as a part of the Colorado River delta fan tributary to the Salton Sea basin.

\section{WATER REQUIREMENTS}

By the importation of Colorado River waters, this desert valley has been converted into one of the most productive agricultural areas in the country. Practically all of the valley is within the boundaries of the Imperial Irrigation District, one of the largest irrigation districts in the United States. Its gross service area exceeds 600,000 acres, of which more than 400,000 acres are now irrigated. This present service area accounts for about one-third of all the irrigated lands in southern California and all but about 2 percent of the irrigated lands in Imperial County. In $1951 \mathrm{Im}$ perial County produced $\$ 109,000,000$ worth of agricultural crops (Los Angeles County Board of Supervisors, 1952). Chief among these crops were alfalfa, cattle, lettuce, sugar beets, carrots, flax, and cotton.

Because of a favorable climate, crops grow the year round, and irrigation water deliveries in January are almost half as large as those in July. The water requirements for all crops are very high, being comparable with those in Coachella Valley.

The gross annual diversions of the Imperial Irrigation District from the Colorado River through the old Alamo Canal, for irrigation in California and Mexico, and later through the All-American Canal for the Imperial and Coachella Valleys have been shown on figure 12. The net annual diversions or deliveries to the consumer are shown on figure 48 for the period since 1922. Before 1935 these deliveries depended upon the unregulated flow of the river and the agricultural economies of the moment. Since that date the flow in the lower Colorado River has been largely regulated by the storage developed at Lake Mead and Lake Mohave.

In common with all of southern California there has been a fairly steady increase in the valley's water requirements since the previous drought ending in 1934. In fact, since 1941 the water deliveries have increased at a rate of 63,000 acre-feet per year to give a peak delivery of about 1,880,000 acre-feet in 1951 .

The domestic water requirements of the more than 60,000 people residing in the valley are relatively insignificant when compared with the agricultural water requirements. The valley's 


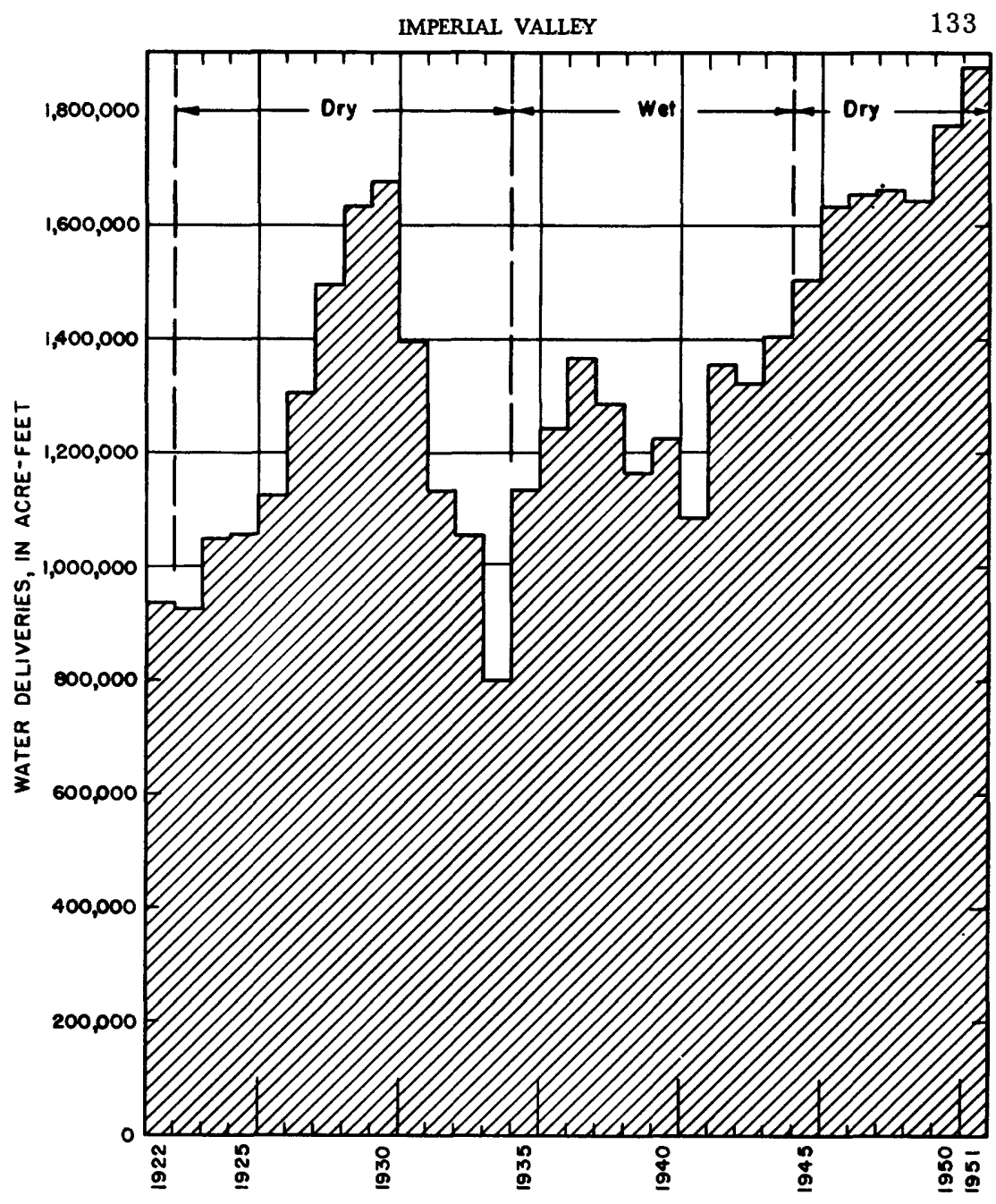

Figure 48. - Annual water deliveries to the Imperial Valley.

principal cities of El Centro and Brawley had populations of more than 10,000 in 1950 .

\section{WATER RESERVES}

Unlike many of southern California's alluvial valleys, the Imperial Valley is not nestled between lofty mountain ranges, where the heavier precipitation on these higher altitudes and subsequent runoff forms the recharge that sustains the valley's water supply. In contrast, the Imperial Valley is a broad flat plain walled in by low, barren mountain ranges, all in a region of continuous aridity. As a consequence, the valley's local water reserves are negligible. 
The prosperity of the valley is entirely dependent upon the runoff from the large, mountainous Colorado River basin. The extreme variability of the runoff in the lower Colorado River has been largely reduced by storage in Lake Mead and Lake Mohave. A continuous record of the combined storage in these two reservoirs since 1935 is shown on figure 49: The contents of these reservoirs, together with the annual inflow into them, represent the water reserves of all the diverters, including Imperial Valley, from the lower Colorado River. Since their first filling, these reservoirs have had a minimum content of more than $16,000,000$ acre-feet.

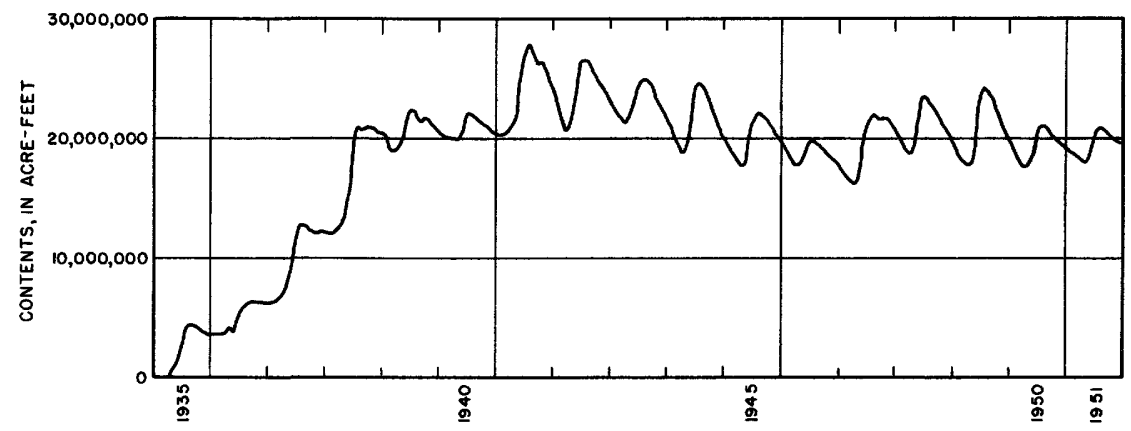

Figure 49. - Combined contents of Lake Mead and Lake Mojave.

\section{EFFECT OF DROUGHT OF 1944-51}

There is of course no evidence in Imperial Valley of the effects of the drought of 1944-51. This is because the water supplies and reserves originating in the valley are negligible. For that reason, the water supply of this valley will be affected only by droughts or water shortages in the Colorado River basin.

\section{REFERENCES CITED}

Adams, Frank, and Huberty, M. R., 1933, Value and cost of water for irrigation in coastal plain of southern California: Calif. Dept. Public Works, Water Res. Div. Bull. 43.

Banks, H. O., 1952, Water quality problems in Califomia: 25th Ann. Mtg., Assoc. of Western State Engineers.

Blaney, H. F., 1952, Consumptive use of water, a Symposium: Am. Soc. Civil Engineers Trans., v. 117, p. 949-973.

California Conservation Commission, 1912, Report of Conservation Commission of the State of California, $502 \mathrm{p}$.

California Division of Water Resources, 1933, Ventura County investigation: Calif. Dept. Public Works, Water Res. Div., Bulls. 46 and $46 a$.

1934, Mojave River investigation: Calif. Dept. Public Works, Water Res. Div., Bull. 47. 249 p. $44 \mathrm{p}$. 
Carpenter, E. J., and Stanley, W. C., 1922, Soil survey of the Lancaster area, Calif.: U. S. Dept. Agr., Bur, of Soils, Field Operations.

Chapman, C. E., 1939, A history of California-the Spanish period: New York, The Macmillan Co., 577 p.

Citizens' Committee for Cachuma Water, 1949, A water history and the Cachuma project; Santa Barbara, Calif., 20 p.

City of Los Angeles, 1916, Complete report on construction of the Los Angeles Aqueduct, Dept. Public Service.

City of San Buenaventura, 1948, Ordinance No. 704.

City of Santa Barbara, 1948, Ordinance No. 2174, Santa Barbara News-Press, Jan. 16, 1948.

Cleland, R. G., 1939, A history of California-the American period: New York, The Macmillan Company, 512 p.

Eckis, R., 1934, Geology and ground-water storage capacity of valley fill (South Coastal Basin Investigation): Calif. Dept. Public Works, Water Res. Div., Bull. 45. 273 p.

Ellis, A. J., and Lee, C. H., 1919, Geology and ground waters of the western part of San Diego County, Calif.: U. S. Geol. Survey, Water-Supply Paper 446.

Gleason, G. B., 1947a, South coastal basin investigation, overdraft on ground-water basins: Calif. Dept. Public Works, Water Res. Div., Bull. 53, 256 p.

$-1947 \mathrm{~b}$, Report to the Assembly of the State Legislature on water supply of Antelope Valley in Los Angeles and Kern Counties, $22 \mathrm{p}$.

1951, Consumptive use in municipal and industrial areas: Am. Soc. Civil Engineers Trans., v. 117, p. 1004-1009.

Hall, W. H., 1888, Irrigation in California (southern), Sacramento. Calif. 672 p.

Hoyt, J. C., 1936, Droughts of 1930 to 1934: U. S. Geol. Survey, Water-Supply Paper 680.

Hoyt, W. G., 1942, Droughts, in Meinzer, O. E. Hydrology: New York, McGraw-Hill Book Co, p. 579-591.

Hurd, W. E., 1939, North Pacific Ocean, September 1939: Monthly Weather Rev., v. 67, p. 356-358.

Jenkins, Ol af P., 1938, Geologic map of California, Calif. Div. Mines.

Johnson, H. R., 1911, Water resources of Antelope Valley, Calif.: U. S. Geol. Survey, Water-Supply Paper 278.

Laverty, F. B., 1946, Correlating flood control and water-supply, Los Angeles coastal plain: Am. Soc. Civil Engineers Trans., v. 111, p. 1127-1144.

Los Angeles Chamber of Commerce, 1951, Electric energy use in Los Angeles city and in the Los Angeles metropolitan area, 24th ann. rept.

Los Angeles County Agricultural Commissioner, 1951, Crop report.

Los Angeles County Board of Supervisors, 1952, Southern California agriculture.

Los Angeles County Flood Control District, 1948, Biennial report on hydrological data.

Lynch, H. B., 1931, Rainfall and stream runoff in southern California since 1769 Metropolitan Water District of Southern California, Los Angeles, 31 p.

McGlashan, H. D., and Briggs, R. C., 1939, Floods of December 1937 in northem California: U. S. Geol. Survey, Water-Supply Paper 843.

Merriam, Richard, 1951, Ground water in the bedrock in western San Diego County, Calif.: Div. of Mines, Bull. 159.

Mendenhall, W. C., 1905a, Development of underground waters in the eastern coastal plain region of southern California: U. S. Geol. Survey, Water-Supply Paper 137.

$1905 b$, Development of underground waters in the central coastal plain region of southern California: U. S. Geol. Survey, Water-Supply Paper 138.

$1905 c$, Developmęnt of underground waters in the western coastal plain region of southern California: U. S. Geol. Survey, Water-Supply Paper 139.

1905d, Hydrology of San Bernardino Valley, Calif.: U. S. Geol. Survey, WaterSupply Paper 142.

1908 , Ground water and irrigation enterprises in the foothill belt, southern California: U. S. Geol. Survey, Water-Supply Paper 219.

1909, Ground waters of the Indio region, Calif.: U. S. Geol. Survey, Water-Supply Paper 225.

Metropolitan Water District of Southern California, 1939, History and first annual report: Los Angeles.

Muckel, D. C., and Blaney, H. F., 1945, Utilization of the waters of lower San Luis Rey Valley, San Diego County, Calif.: U. S. Dept. of Agr., Soil Conserv. Service, Div. of Irrigation.

Nadeau, R. A., 1950, The water seekers, Garden City, N. Y. Doubleday \& Co., 309 p.

Pillsbury, A. F., 1941, Observations on use of irrigation water in Coachella Valley, Calif.: Calif. Agr. Exp. Sta., Bull. 649. 
Rafter, G. W., 1899, Sewage irrigation: U. S. Geol. Survey, Water-Supply Paper 22.

Schulman, Edmund, 1947, Tree-ring hydrology in southern California: Univ. of Ariz., Lab. of Tree-ring Research, Bull. 4.

Slichter, Charles S., 1905, Field measurements of the rate of movement of underground waters: U. S. Geol. Survey, Water-Supply Paper 140.

Stafford, H. M., and Troxell, H. C., 1953, Coastal basins near Los Angeles, Calif._-The Physical and economic foundation of natural resources, part IV, Interior and Insular Affairs Committee, House of Representatives, U. S. Congress.

State Water Resources Board, 1951, Water resources of California: Bull. 1, Sacramento, Calif., 648 p.

Storie, R. E., and Trussel, D. F., 1933, Soil survey of Barstow area, Calif.: U. S. Dept. of Agr., Bur. Chemistry and Soils, Bull.

Symons, H. H., 1942, California mineral production and directory of mineral producers for 1941: Calif. Div. of Mines.

Tait, C. E., 1912, Irrigation resources of southern California: Calif. rept., Conserv. Comm. p. 241-327.

Thompson, D. G., 1929, The Mohave Desert region, Calif.: U. S. Geol. Survey, WaterSupply Paper 578.

Thornthwaite, C. W., 1931, The climates of North America according to a new classification: Geog. Rev., v. 21.

-1948, An approach toward a rational classification of climate: Geog. Rev., v. 38, p. 55-94.

Troxell, H. C., 1933, Ground-water supply and natural losses in the valley of the Santa Ana River between Riverside narrows and Orange County line: Calif. Dept. Public Works, Water Res. Div., Bull. 44, p. 141-172.

-1948, Hydrology of western Riverside County, Calif.: Riverside County Flood Control and Water Conserv. Dist. rept.

Troxell, H. C. and others, 1942, Floods of March 1938 in southern California: U. S. Geol. Survey, Water-Supply Paper 844.

Troxell, H. C., and Stafford, H. M., 1949, Natural water losses in mountain drainage areas of southern California: Am. Geophys. Union. Trans., v. 30, p. 752-758.

Troxell, H. C., Poland, J. F., and others, 1951, Some aspects of the water supply in the South Coastal basin, Calif.: U. S. Geol. Survey, Circ. 105.

Troxell, H. C., and Hofmann, W., 1954, Hydrology of the Mojave Desert; Geology of Southern California: Calif. Division of mines, Bull. 170, chap. 6, p. 13-17.

Troxell, H. C., and others, 1954, Hydrology of the San Bernardino and eastern San Gabriel Mountains, Calif.: U. S. Geol. Survey, Hydrol. Inv. Atlas HA-1.

U. S. Bur. Recl., 1952, Report on Victor project, Calif., Boulder City, Nev., 42 p.

U. S. Dept. of Interior, 1951, The drought in southwestern United States, as of October 1951: Washington, D. C., 65 p.

U. S. Public Health Service, 1951, California drainage basins, Pub. 86.

U. S. Weather Bureau, 1951, Local climatological summary.

Upson, J. E., 1951, Geology and ground-water resources of the south coast basins of Santa Barbara County, Calif.: U. S. Geol Survey, Water-Supply Paper 1108.

Upson, J. E., and Thomasson, H. G., Jr., 1951, Geology and water resources of the Santa Ynez River basin, Santa Barbara County, Calif.: U. S. Geol. Survey, WaterSupply Paper 1107.

Worts, G. F., Jr., 1951, Geology and ground-water resources of the Santa Maria Valley area, Calif.: U. S. Geol. Survey, Water-Supply Paper 1000.

Young, A. A., 1945, Irrigation requirements of California crops: Calif, Dept. Public Works, Water Res. Div., Bull. 51, 128 p.

1948, Evaporation from water surface in Califomia: Calif. Dept. Public Works, Water Res. Div., Bull. 54-A, 200 p. 


\section{INDEX}

A

Page
Page

Ground water-Continued

Los Angeles region....................... 79-92

Mojave River basin...................... 116-124

recoverable.................................. 28

reserves, described......................50, 65

maintaining...............................55 55

San Diego region........................64-67

Santa Barbara region..................106-111

storage capacity, Los Angeles region.....28

use............................................. 35

Ventura region..........................96-102

Whitewater River basin................ 124-130

\section{I}

Imperial Valley, cultural development..... 36 drought of $1944-51 \ldots . . . \ldots \ldots \ldots . . . \ldots \ldots \ldots . . .134$ water requirements..........................132

water reserves...............................133

Imported water, Southern California.... 51-52 Los Angeles region......................70, 76

San Diego region.............................62

Imperial Valley........................132-133

Irrigated areas, in acres for period 1900-1950................................44

Antelope Valley basin.......................113

distribution..................................4-5

Imperial Valley.............................132

Mojave River basin......................... 116

Santa Barbara region...................... 105

Ventura region....................................94

Whitewater River basin.................... 126

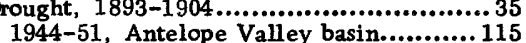

Imperial Valley.............................134

Los Angeles region........................76-92

Mojave River basin...................120-124

purpose and scope of study.................3-6

San Diego region........................62-67

Santa Barbara region.................. 106-111

Ventura region......................... 95-103

Whitewater River basin....................130

what consti tutes.................................6-8

Droughts, early..................................... 31

recent.......................................... 29

\section{E-F}

Effective precipitation, Coachella Valley ...47 Santa Ana area..................................47 Upland..............................................47

Evapotranspiration, potential.....12, 20-22, 47 uneconomic.....................................53

Fillmore basin, drought of 1944-51.......95-98

Flow to ocean, waste..............................52

\section{$\mathbf{G}$}

Goleta basin, drought of 1944-51

Ground water, Antelope Valley basin.. 112-115

\section{$\mathbf{L}$}

Las Posas valley, drought of 1944-51......102

Los Angeles aqueduct.......................... 36

Los Angeles region, drought of

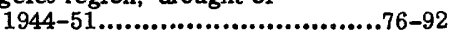

ground water...............................79-92

mountain and foothill areas............70-73

precipitation.............................70-73 runoff...................71-74, 77-78, 81, 83 surface water............................ 77-79

water requirements......................67-70

water reserves, mountain and foothill areas..................................70-73

overdraft..................................76 76

recharge.................................. 74-76

valley floor areas..................... 73-74

M

Mendenhall, W. C., quoted.

Mojave River basin, drought of

$1944-51 \ldots \ldots \ldots \ldots \ldots \ldots \ldots \ldots . . \ldots . . . . .120-124$

runoff...................................116-119

water requirements.....................116-118

water reserves..........................118-120 
Mojave River Valley drought of 1944-51, Lower...................123-124 Middle. Upper.................................. 120-121

Mono basin, aqueduct.......................... 39

water imported from.......................51

Montalvo basin, drought of 1944-51......... 99

Ojai Valley, drought of 1944-51............100

Oxnard plain, drought of $1944-51 . . . . . . . . . .98$

Overdraft of water reserves, Los Angeles

region..................................76

Ventura region............................99, 102

Owens basin, water imported from............51

\section{P}

Piru basin, drought of 1944-51...............98 Pleasant Valley, drought of 1944-51........99

Population for period 1850-1950.............43 Precipitation, average annual for

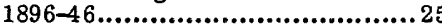
chronological distribution............... 14-19 coastal area..............................16-18 cyclic distribution of annual.................. 18 desert area.....................................19 Los Angeles region........................ 70-73 mean monthly distribution..................10 Mojave River basin...................116, 118 mountain area ............................18-19

San Diego region............................60

Ventura region...............................92

White River basin.......................... 125

\section{$\mathbf{R}$}

Recharge of water reserves, Los Angeles region...............................74-76

Relative humidity..........................12-13

Reservoir, Big Bear Lake.......................79

Reservoirs, storage capacity and purpose.............................50, 63

Runoff, Antelope Valley basin.........113-115 cyclic distribution of annual...............27 Los Angeles region.....71-74, 77-78, 81, 83 Mojave River basin...................116-119 San Diego region...................60-64, 66 Santa Barbara region.............106-107, 109 surface.................................. 26 Ventura region................92, 95-96, 101 waste flow to ocean......................... 52 Whitewater River basin.................... 129

\section{$\mathbf{S}$}

San Diego aqueduct...........................40 San Diego region, drought of 1944-51...62-67 ground water...............................64-67 runoff ............................60-64, 66 surface water............................. 63-64 water importation.............................62 water requirements...................... 57-60 water reserves............................ 60-62

San Fernando Valley, drought of $1944-51$

ground water.......................... 87-89
San Jacinto basin, drought of $1944-51$

ground water .........................85-87

Santa Ana Valley, Upper ground water.................................. 82-89

Santa Barbara region, drought of $1944-51 . . . \ldots \ldots \ldots . . . . . . . . . . . . . . .106-111$

runoff............................106-107, 109 water requirements................... 104-106

water reserves............................... 106

water supply.................................41

Santa Maria Valley, drought of

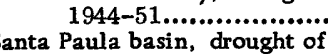
1944-51........................... 95-98

Santa Rosa valley, drought of 1944-51.... 102

Santa Ynez valley, drought of $1944-51 \ldots . .108$

Sea-water encroachment......................66

Sewage, water waste from................ 53-54

Simi valley, drought of $1944-51 \ldots . . \ldots \ldots \ldots . .100$

Surface water, Los Angeles region....... 77-79 recoverable............................... 25-28 reserves.....................................48-50 San Diego region........................63-64 See also Runoff.

\section{$\mathrm{T}-\mathrm{V}$}

Temperature, mean monthly distribution...11 Tree-ring growth, annual......................22

Ventura region, drought of $1944-51 . . .95-103$ runoff........................92, 95-96, 101 water requirements ....................... 93-94 water reserves.......................... 94-95 Ventura River Valley, Upper, drought

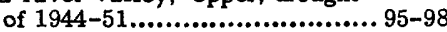

W

Waste water. $52-54$

See also Runoff

Waste to ocean, Los Angeles region

valley floor areas........................ 74

Water, annual consumption of native vegetation........................... 22-24 artesian..........................112, 126 deliveries............. 59-60, 67-69, 93-94, $104,118,127,132-133$

See also Water requirements.

imported.........51-52, 62, 70, 76, 132-133 recoverable............................24-28 See also Runoff.

Water requirements, agricultural........ 46-48 Antelope Valley basin......................112 domestic and industrial......................45

Imperial Valley...............................132 Los Angeles region.....................67-70

Mojave River basin....................116-118 native vegetation..........................20-24

Santa Barbara region....................104-106 San Diego region......................... 57-60

Ventura region.......................... 93-94

Whitewater River basin.............. 126-129 Water reserves, Antelope Valley

basin.............................. 113-115 effect of cultural development on.... 48-54 Imperial Valley...............................133 Los Angeles region......................... 70-76 Mojave River basin.....................118-120 
Water reserves-Continued

Page overdraft, Los Angeles region...............76 San Di ego region........................ 60-62 Santa Barbara region........................106 surface........................................48 48-50

Ventura region............................ 94-95

Whitewater River basin................... 129

See also Ground water; Imported water; Surface water; Waste water.

Water rights, values......................... 34-35
Page

Water supply, cultural influences on.........55

Santa Barbara ................................41

See also Water requirements; Water reserves.

Whitewater River basin, drought of 1944-51...............................130

runoff........................................129

water requirements....................126-129

water reserves...............................129

U. S. GOVERNMENT PRINTING OFFICE : 1957 O -425139 
